\title{
NTP TECHNICAL REPORT ON THE TOXICITY STUDIES OF \\ Cedarwood Oil (Virginia) \\ (CASRN 8000-27-9) \\ ADMINISTERED DeRMALLY TO \\ F344/N RATS AND \\ B6C3Fl/N MICE
}

NTP TOX 86

NOVEMBER 2016 


\section{NTP Technical Report on the Toxicity Studies of Cedarwood Oil (Virginia) (CASRN 8000-27-9) Administered Dermally to F344/N Rats and B6C3F1/N Mice}

Toxicity Report 86

November 2016

National Toxicology Program

Public Health Service

U.S. Department of Health and Human Services

ISSN: 2378-8992

Research Triangle Park, North Carolina, USA 


\section{Foreword}

The National Toxicology Program (NTP) is an interagency program within the Public Health Service (PHS) of the Department of Health and Human Services (HHS) and is headquartered at the National Institute of Environmental Health Sciences of the National Institutes of Health (NIEHS/NIH). Three agencies contribute resources to the program: NIEHS/NIH, the National Institute for Occupational Safety and Health of the Centers for Disease Control and Prevention (NIOSH/CDC), and the National Center for Toxicological Research of the Food and Drug Administration (NCTR/FDA). Established in 1978, NTP is charged with coordinating toxicological testing activities, strengthening the science base in toxicology, developing and validating improved testing methods, and providing information about potentially toxic substances to health regulatory and research agencies, scientific and medical communities, and the public.

The Toxicity Study Report series began in 1991. The studies described in the Toxicity Study Report series are designed and conducted to characterize and evaluate the toxicologic potential of selected substances in laboratory animals (usually two species, rats and mice). Substances selected for NTP toxicity studies are chosen primarily on the basis of human exposure, level of production, and chemical structure. The interpretive conclusions presented in the Toxicity Study Reports are based only on the results of these NTP studies. Extrapolation of these results to other species, including characterization of hazards and risks to humans, requires analyses beyond the intent of these reports. Selection per se is not an indicator of a substance's toxic potential.

NTP conducts its studies in compliance with its laboratory health and safety guidelines and FDA Good Laboratory Practice Regulations and must meet or exceed all applicable federal, state, and local health and safety regulations. Animal care and use are in accordance with the Public Health Service Policy on Humane Care and Use of Animals. Studies are subjected to retrospective quality assurance audits before being presented for public review.

NTP Toxicity Study Reports are indexed in National Center for Biotechnology Information (NCBI) Bookshelf database and are available free of charge electronically on the NTP website (http://ntp.niehs.nih.gov). Additional information regarding this study may be requested through Central Data Management (CDM) atcdm@niehs.nih.gov. Toxicity data are available through NTP's Chemical Effects in Biological Systems (CEBS) database: https://www.niehs.nih.gov/research/resources/databases/cebs/index.cfm. 


\section{Table of Contents}

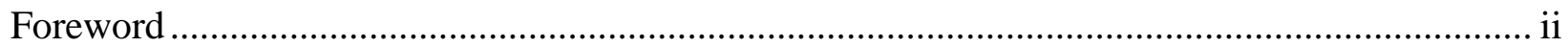

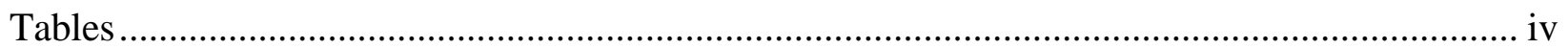

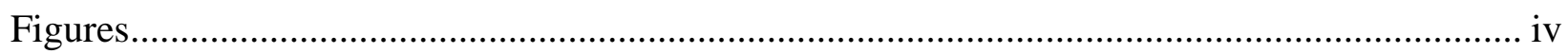

About This Report............................................................................................................ vi

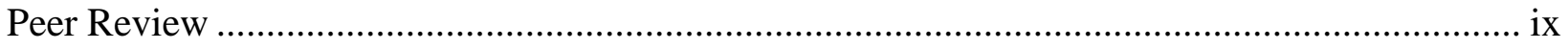

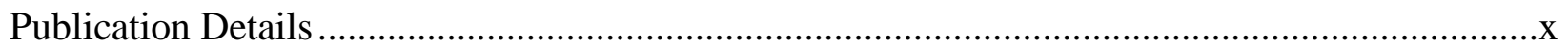

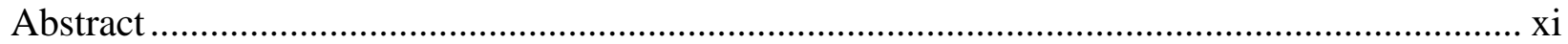

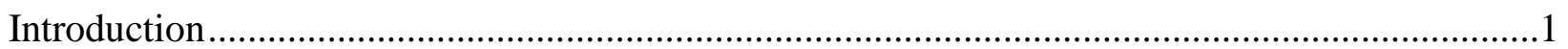

Chemical and Physical Properties ...........................................................................................

Production, Use, and Human Exposure …………….......................................................2

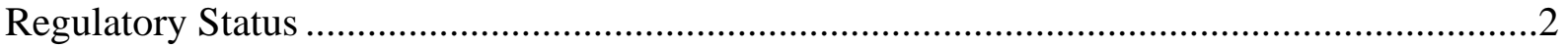

Absorption, Distribution, Metabolism, and Excretion ...............................................................

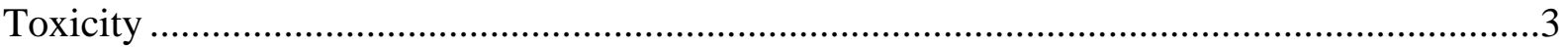

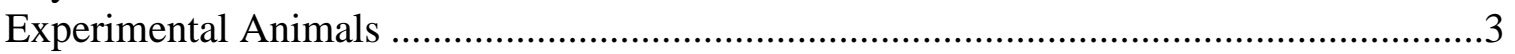

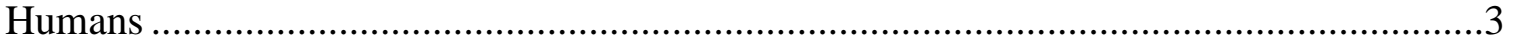

Reproductive and Developmental Toxicity ..........................................................................

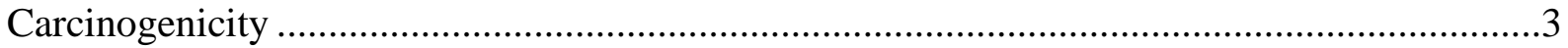

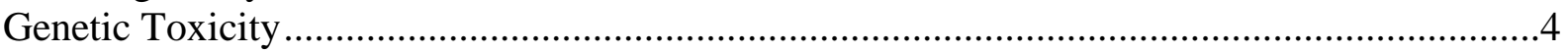

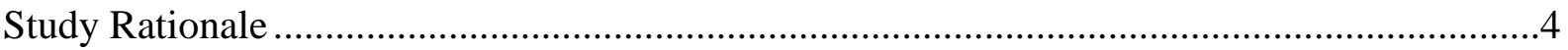

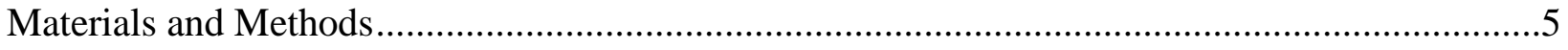

Procurement and Characterization ........................................................................................

Virginia Cedarwood Oil...............................................................................................

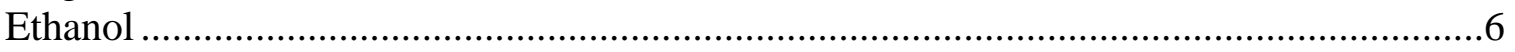

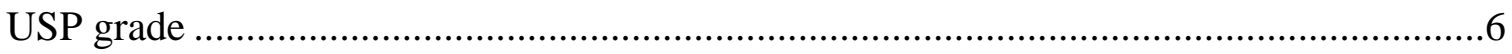

Preparation and Analysis of Dose Formulations.................................................................6

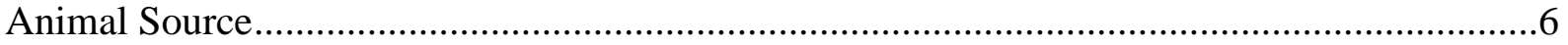

Animal Welfare

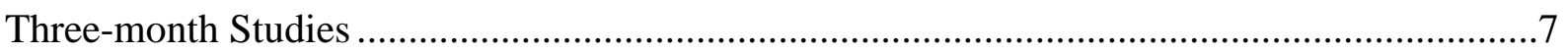

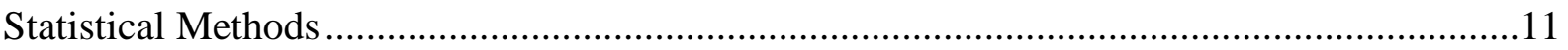

Calculation and Analysis of Lesion Incidences .............................................................11

Analysis of Continuous Variables..................................................................................11

Quality Assurance Methods ...............................................................................................11

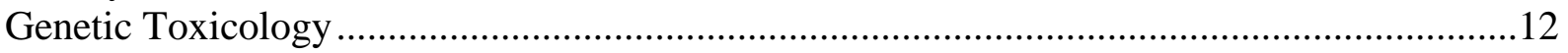

Salmonella typhimurium Mutagenicity Test Protocol .......................................................12

Mouse Peripheral Blood Micronucleus Test Protocol .......................................................12

Evaluation Protocol....................................................................................................13

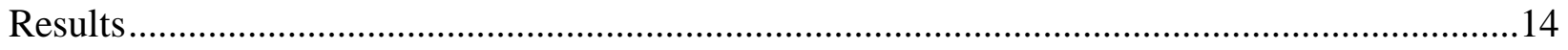

Three-month Study in Rats ................................................................................................

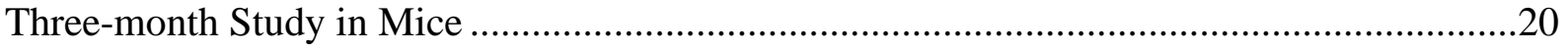

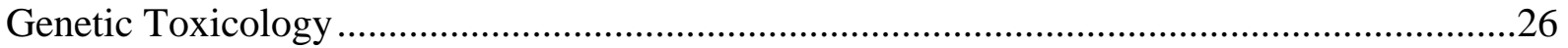




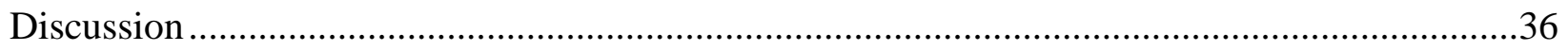

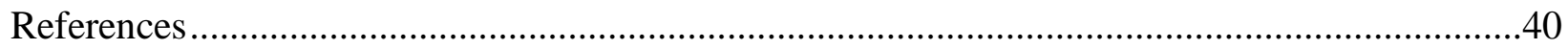

Appendix A. Summary of Nonneoplastic Lesions in Rats and Mice .......................................... A-1

Appendix B. Hematology Results......................................................................................

Appendix C. Organ Weights and Organ-Weight-to-Body-Weight Ratios .....................................-1

Appendix D. Reproductive Tissue Evaluations and Estrous Cycle Characterization ................. D-1

Appendix E. Genetic Toxicology …………………........................................................

Appendix F. Chemical Characterization and Dose Formulation Studies .....................................F-1

Appendix G. Ingredients, Nutrient Composition, and Contaminant Levels in NTP-2000 Rat and Mouse Ration ................................................................................. G-1

Appendix H. Sentinel Animal Program .............................................................................. H-1

\section{Tables}

Table 1. Experimental Design and Materials and Methods in the Three-month Dermal Studies of Cedarwood Oil

Table 2. Survival and Body Weights of Rats in the Three-month Dermal Study of Cedarwood Oil.....

Table 3. Organ Weights and Organ-Weight-to-Body-Weight Ratios for Rats in the Threemonth Dermal Study of Cedarwood Oil

Table 4. Incidences of Nonneoplastic Lesions of the Skin (Site of Application) in Rats in the Three-month Dermal Study of Cedarwood Oil

Table 5. Incidences of Selected Nonneoplastic Lesions in Rats in the Three-month Dermal Study of Cedarwood Oil.

Table 6. Survival and Body Weights of Mice in the Three-month Dermal Study of Cedarwood Oil.

Table 7. Organ Weights and Organ-Weight-to-Body-Weight Ratios for Mice in the Three-month Dermal Study of Cedarwood Oil

Table 8. Incidences of Nonneoplastic Lesions of the Skin (Site of Application) in Mice in the Three-month Dermal Study of Cedarwood Oil

Table 9. Incidences of Selected Nonneoplastic Lesions in Mice in the Three-month Dermal Study of Cedarwood Oil.

\section{Figures}

Figure 1. Virginia Cedarwood Oil (CASRN 8000-27-9)..........................................................1

Figure 2. Growth Curves for Rats Administered Cedarwood Oil Dermally for

Three Months.

Figure 3. Growth Curves for Mice Administered Cedarwood Oil Dermally for

Three Months.

Figure 4. Normal Skin (Site of Application) of a Vehicle Control Female F344/N Rat in the Three-month Dermal Study of Cedarwood Oil (H\&E) 
Figure 5. Higher Magnification of Figure 4 (H\&E)

Figure 6. Hyperplasia and Hyperkeratosis of the Epidermis (Site of Application) in the

Skin of a Female F344/N Rat Administered 100\% Cedarwood Oil Dermally for Three Months (H\&E) .........................................................................................28

Figure 7. Higher Magnification of Figure 6 (H\&E) …………………………........................2

Figure 8. Epidermal Hyperkeratosis in the Skin (Site of Application) of a Female F344/N

Rat Administered 100\% Cedarwood Oil Dermally for Three Months (H\&E).............29

Figure 9. Higher Magnification of Figure 8 (H\&E) ………………….......................................30

Figure 10. Focal Epidermal Ulcer in the Skin (Site of Application) of a Female F344/N Rat Administered 100\% Cedarwood Oil Dermally for Three Months (H\&E)..............30

Figure 11. Marked Chronic Active Inflammation in the Skin (Site of Application) of a Female F344/N Rat Administered 100\% Cedarwood Oil Dermally for Three Months (H\&E) .31

Figure 12. Higher Magnification of Figure 11 (H\&E) 31

Figure 13. Dermal Fibrosis in the Skin (Site of Application) of a Female F344/N Rat Administered 100\% Cedarwood Oil Dermally for Three Months (H\&E) ...

Figure 14. Renal Tubule Degeneration in the Kidney of a Male F344/N Rat Administered 100\% Cedarwood Oil Dermally for Three Months (H\&E) ..........................................32

Figure 15. Granular Casts in the Kidney of a Male F344/N Rat Administered 100\% Cedarwood Oil Dermally for Three Months (H\&E)

Figure 16. Higher Magnification of Figure 15 Showing Several Renal Tubules that are Occluded and Distended by Eosinophilic, Granular Casts (Asterisks) (H\&E) .33

Figure 17. Normal Kidney of a Vehicle Control Male F344/N Rat in the Three-month Dermal Study of Cedarwood Oil Showing Uniformly Fine, Eosinophilic (Hyaline) Droplets (Arrows) within the Cytoplasm of Several Renal Tubule Epithelial Cells (H\&E) .

Figure 18. Normal Kidney of a Vehicle Control Male F344/N Rat in the Three-month Dermal Study of Cedarwood Oil Stained with the Mallory-Heidenhain Stain (Mallory-Heidenhain)

Figure 19. Kidney of a Male F344/N Rat Administered 100\% Cedarwood Oil Dermally for Three Months (H\&E)

Figure 20. Kidney of a Male F344/N Rat Administered 100\% Cedarwood Oil Dermally for Three Months Stained with the Mallory-Heidenhain Stain for Protein (Mallory-Heidenhain)

This report has been reformatted to meet new NTP publishing requirements; its content has not changed. 


\section{About This Report}

National Toxicology Program ${ }^{1}$

${ }^{1}$ Division of the National Toxicology Program, National Institute of Environmental Health

Sciences, Research Triangle Park, North Carolina, USA

\section{Collaborators}

N.R. Catlin, R.A. Herbert, B. Atkinson, C.R. Blystone, C.A. Colleton, L.M. Fomby, P.M. Foster, M.M. Gruebbel, M.H. Hamlin, II, M.R. Hejtmancik, G.D. Hill, M.J. Hooth, A.P. King-Herbert, G.E. Kissling, D.E. Malarkey, B.S. McIntyre, R.A. Miller, R.R. Moore, B.J.T. Muir, M.J. Ryan, S.L. Smith-Roe, M.D. Stout, I.O. Surh, J.D. Toft, II, G.S. Travlos, M.K. Vallant, S.

Waidyanatha, N.J. Walker, Y. Wang, K.L. Witt

Division of the National Toxicology Program, National Institute of Environmental Health Sciences, Research Triangle Park, North Carolina, USA

Evaluated and interpreted results and reported findings

N.R. Catlin, Ph.D., Study Scientist

R.A. Herbert, D.V.M., Ph.D., Study Pathologist

C.R. Blystone, Ph.D.

P.M. Foster, Ph.D.

M.J. Hooth, Ph.D.

A.P. King-Herbert, D.V.M.

G.E. Kissling, Ph.D.

D.E. Malarkey, D.V.M., Ph.D.

B.S. McIntyre, Ph.D.

S.L. Smith-Roe, Ph.D.

M.D. Stout, Ph.D.

I.O. Surh, Ph.D.

G.S. Travlos, D.V.M.

M.K. Vallant, M.T.

S. Waidyanatha, Ph.D.

N.J. Walker, Ph.D.

K.L. Witt, M.S.

Battelle Columbus Operations, Columbus, Ohio, USA

Conducted studies and evaluated pathology findings

M.R. Hejtmancik, Ph.D., Principal Investigator

C.A. Colleton, D.V.M.

L.M. Fomby, D.V.M., Ph.D.

M.J. Ryan, D.V.M., Ph.D.

J.D. Toft, II, D.V.M.

Experimental Pathology Laboratories, Inc., Research Triangle Park, North Carolina, USA Conducted pathology review

M.H. Hamlin, II, D.V.M., Principal Investigator

M.M. Gruebbel, D.V.M., Ph.D. 
R.A. Miller, D.V.M., Ph.D.

R.R. Moore, D.V.M., Ph.D.

Coordinated NTP Pathology Peer Review (Special Report; November 7, 2013)

R.R. Moore, D.V.M., Ph.D.

ILS, Inc., Research Triangle Park, North Carolina, USA

Coordinated NTP Pathology Working Group (April 5, 2007)

G.D. Hill, D.V.M., Ph.D.

Bridge Global Pharmaceutical Services, Inc., Gaithersburg, Maryland, USA

Provided SMVCE analysis

B.J.T. Muir, Ph.D., Principal Investigator

B. Atkinson, M.Sc.

Y. Wang, M.S.

\section{Contributors}

NTP Pathology Working Group, National Institute of Environmental Health Sciences, Research Triangle Park, North Carolina, USA

Participated in NTP Pathology Working Group (April 5, 2007)

S.A. Elmore, D.V.M., M.S., National Toxicology Program

G.P. Flake, M.D., National Toxicology Program

R.A. Herbert, D.V.M., Ph.D., National Toxicology Program

D.E. Malarkey, D.V.M., Ph.D., National Toxicology Program

J.B. Nold, D.V.M., Ph.D., GlaxoSmithKline

N. Wakamatsu, D.V.M., Ph.D., National Toxicology Program

NTP Pathology Peer Review (Special Report), National Institute of Environmental Health Sciences, Research Triangle Park, North Carolina, USA

Participated in NTP Pathology Peer Review (November 7, 2013)

M.F. Cesta, D.V.M., Ph.D., National Toxicology Program

G.P. Flake, M.D., National Toxicology Program

M.M. Gruebbel, D.V.M., Ph.D., Experimental Pathology Laboratories, Inc.

R.A. Herbert, D.V.M., Ph.D., National Toxicology Program

K. Janardhan, Ph.D., ILS, Inc.

D.E. Malarkey, D.V.M., Ph.D., National Toxicology Program

R.A. Miller, D.V.M., Ph.D., Experimental Pathology Laboratories, Inc.

Experimental Pathology Laboratories, Inc., Research Triangle Park, North Carolina, USA Supervised pathology review

M.H. Hamlin, II, D.V.M., Principal Investigator

Dynamac Corporation, Research Triangle Park, North Carolina, USA

Prepared quality assessment audits

S. Brecher, Ph.D., Principal Investigator

S. Iyer, B.S. 


\section{Cedarwood Oil, NTP TOX 86}

V.S. Tharakan, D.V.M.

Social \& Scientific Systems, Inc., Research Triangle Park, North Carolina, USA

Provided statistical analyses

M.V. Smith, Ph.D., Principal Investigator

L.J. Betz, M.S.

S.F. Harris, B.S.

Biotechnical Services, Inc., Little Rock, Arkansas, USA

Prepared Toxicity Study Report

S.R. Gunnels, M.A., Principal Investigator

L.M. Harper, B.S.

J.I. Irving, M.A.P.

T.S. Kumpe, M.A.

D.C. Serbus, Ph.D. 


\section{Peer Review}

The draft NTP Technical Report on the Toxicity Studies of Cedarwood Oil (Virginia) (CASRN 8000-27-9) Administered Dermally to F344/N Rats and B6C3F1/N Mice was evaluated by the reviewers listed below. These reviewers served as independent scientists, not as representatives of any institution, company, or governmental agency. In this capacity, reviewers determined if the design and conditions of these NTP studies were appropriate and ensured that this Toxicity Study Report presented the experimental results and conclusions fully and clearly.

\section{Peer Reviewers}

\section{Gregory L. Erexson, Ph.D.}

Preclinical Safety

Research \& Development

AbbVie, Inc.

North Chicago, Illinois, USA

Laura A. Hansen, Ph.D.

Department of Biomedical Sciences

Creighton University School of Medicine

Omaha, Nebraska, USA 


\section{Publication Details}

Publisher: National Toxicology Program

Publishing Location: Research Triangle Park, NC

ISSN: 2378-8992

DOI: https://doi.org/10.22427/NTP-TOX-86

Report Series: NTP Toxicity Report Series

Report Series Number: 86

Official citation: National Toxicology Program (NTP). 2016. NTP technical report on the toxicity studies of cedarwood oil (Virginia) (CASRN 8000-27-9) administered dermally to F344/N rats and B6C3F1/N mice. Research Triangle Park, NC: National Toxicology Program. Toxicity Report 86. 


\section{Abstract}

Virginia cedarwood oil (hereafter referred to as cedarwood oil) is extracted from Juniperus virginiana trees by steam distillation and contains cedrol, cedrene, cedrenol, cedral, cuperene, thujopsene, and widdrol as primary components. Cedarwood oil is used as a fragrance in cosmetic products, as a pesticide, and as a source material for production of other fragrance materials with cedarwood odors. Cedarwood oil was nominated for toxicity testing by the National Cancer Institute based on widespread and potentially increasing human exposure to the substance, and a lack of toxicology data. The dermal route of administration was selected for these studies because it is the most common route of exposure in humans due to its frequent use as a pesticide and as a fragrance in household products and cosmetics. Male and female F344/N rats and B6C3F1/N mice were administered cedarwood oil dermally for 3 months. Genetic toxicology studies were conducted in Salmonella typhimurium and mouse peripheral blood erythrocytes.

Groups of 10 male and 10 female rats and mice received no treatment (untreated control) or were administered cedarwood oil in 95\% aqueous ethanol dermally at concentrations of $0 \%$ (vehicle control), $6.25 \%, 12.5 \%, 25 \%, 50 \%$, or $100 \%$ (neat) 5 days per week for 14 weeks. Formulations were administered at a volume of $0.5 \mathrm{~mL} / \mathrm{kg}$ body weight (rats) or $2.0 \mathrm{~mL} / \mathrm{kg}$ (mice), which resulted in the mice receiving higher doses of cedarwood oil than rats in respect to the equivalent dose in $\mathrm{mg} / \mathrm{kg}$. Dose ranges for mice and rats were estimated as 125 to 2,000 $\mathrm{mg}$ cedarwood oil/kg body weight and 31.25 to $500 \mathrm{mg} / \mathrm{kg}$, respectively. Statistical analyses of effects in dosed groups (except 100\%) were conducted with comparisons to the appropriate vehicle control group; groups dosed with $100 \%$ cedarwood oil were compared to the appropriate untreated control group.

With the exceptions of two males in the 100\% group, all rats survived to the end of the study. Final mean body weights and body weight gains of 50\% and $100 \%$ males and females were significantly less than those of their respective control groups, and the mean body weight gain of male rats in the $25 \%$ group was significantly less than that of the vehicle control group.

Treatment-related clinical observations included irritation, thickening, and ulceration of the skin at the site of application in most males in the $25 \%$ or greater groups and most females in the $12.5 \%$ or greater groups.

In rats, relative liver weights of males in the $50 \%$ and $100 \%$ groups, and absolute and relative liver weights of females in the $100 \%$ group were significantly greater than those in the respective control groups. The absolute kidney weight of $100 \%$ males and relative kidney weights of males in the $50 \%$ and $100 \%$ groups were significantly greater than those in the respective control groups. The absolute thymus weights of $25 \%$ and $100 \%$ males and the absolute and relative thymus weights of $100 \%$ females were significantly less than those in the respective control groups.

Compared to those in the respective control groups, the incidences of several nonneoplastic lesions of the skin at the site of application were significantly increased in dosed groups of male and female rats. The incidences of epidermal hyperplasia were significantly increased in 12.5\% or greater males and all dosed groups of females. The incidences of epidermal hyperkeratosis and sebaceous gland hyperplasia were significantly increased in $25 \%$ or greater males and $12.5 \%$ or greater females. The incidences of epidermal ulcer were significantly increased in the $50 \%$ and $100 \%$ groups of males and females. The incidences of chronic active inflammation were 
significantly increased in $12.5 \%$ or greater males and females. The incidences of dermal fibrosis and hair follicle hyperplasia were significantly increased in $25 \%$ or greater males and females. Hematology effects included increased leukon (white blood cell and differential counts) in 100\% males and $50 \%$ or greater females and treatment-related decreases in erythron (hematocrit, hemoglobin, and erythrocyte counts) in $100 \%$ males and females. In the kidney of rats, the incidences of renal tubule degeneration were significantly increased in 50\% and $100 \%$ males compared to those in the respective control groups. In addition, the incidences of renal tubule granular casts and hyaline droplet accumulation were significantly increased in males in the $25 \%$ or greater groups compared to those in the respective control groups; the severity of these lesions increased with increasing dose. In the bone marrow of rats, the incidences of hyperplasia were significantly increased in $100 \%$ males and females compared to those in the untreated control groups.

Due to the severities of skin lesions at the site of application, all male and female mice in the $100 \%$ groups, one male and one female each in the $50 \%$ groups, and one male in the $12.5 \%$ group were euthanized during weeks 10,11 , and 12 , respectively; all other male and female mice survived to the end of the study. The final mean body weights of $25 \%$ and $50 \%$ males and $12.5 \%$ or greater females and the mean body weight gains of $12.5 \%$ or greater males and females were significantly less than those of the vehicle control groups. Test article-related clinical observations included irritation, thickening, and ulceration of the skin at the site of application in most dosed mice.

In mice, the absolute liver weights of 50\% males and females and relative liver weights of all dosed groups of males and females were significantly greater than those of the vehicle control groups. The absolute kidney weight of $50 \%$ females and relative kidney weights of $12.5 \%$ or greater females were significantly greater than those of the vehicle control groups. Absolute thymus weights of $25 \%$ and $50 \%$ males and $12.5 \%$ or greater females were significantly less than those of the vehicle controls.

The incidences of epidermal hyperplasia, hyperkeratosis, and ulcer and chronic active inflammation, dermal fibrosis, hair follicle hyperplasia, and sebaceous gland hyperplasia were significantly increased in $12.5 \%$ or greater groups of male and female mice compared to those in the respective control groups. In addition, compared to the occurrences in the vehicle control groups, the incidences of epidermal hyperplasia and hyperkeratosis and chronic active inflammation, hair follicle hyperplasia, and sebaceous gland hyperplasia were significantly increased in $6.25 \%$ males, and the incidences of epidermal hyperplasia, chronic active inflammation, and sebaceous gland hyperplasia were significantly increased in $6.25 \%$ females. Hematology effects included increased leukon (white blood cells and differential counts) in $25 \%$ or greater females and treatment-related decreases in erythron (hematocrit, hemoglobin, and erythrocyte counts) in $12.5 \%$ or greater males and $25 \%$ and $50 \%$ females. In the liver, the incidences of hepatocyte glycogen depletion were significantly increased in males and females in the $12.5 \%$ or greater groups compared to those in the respective control groups. In the thymus, the incidences of atrophy were significantly increased in $25 \%$ or greater males compared to those in the respective controls. In the kidney, the incidence of nephropathy was significantly increased in $100 \%$ males compared to that in the untreated controls.

Cedarwood oil was not mutagenic in S. typhimurium strains TA98, TA100, or TA102 with or without exogenous metabolic activation. No increase in micronucleated erythrocytes was seen in blood samples obtained from male B6C3F1/N mice treated with cedarwood oil for 3 months via 
dermal application; a small increase in micronucleated erythrocytes, judged to be equivocal, was seen in female B6C3F1/N mice, however. No significant alterations in the percentage of polychromatic erythrocytes (reticulocytes) were seen in male or female mice, suggesting that dermally-applied cedarwood oil did not induce bone marrow toxicity.

Under the conditions of the 3-month dermal studies with Virginia cedarwood oil, there were treatment-related lesions in male and female rats and mice. Skin (at the site of application) and kidney were the major targets from administration of cedarwood oil in both rats and mice. Additionally, the liver and the thymus were considered secondary targets of cedarwood oil administration as a result of the skin effects at the site of application in both rats and mice. The most sensitive measures of cedarwood oil administration in each species and sex were: increased incidences of skin (site of application) lesions in male [lowest-observed-effect-level $(\mathrm{LOEL})=12.5 \%$; approximately equivalent to $62.5 \mathrm{mg} / \mathrm{kg}$ ] and female (LOEL = 6.25\%; approximately equivalent to $31.25 \mathrm{mg} / \mathrm{kg}$ ) rats and increased incidences of skin (site of application) lesions (LOEL $=6.25 \%$; approximately equivalent to $124 \mathrm{mg} / \mathrm{kg}$ ) in male and female mice.

Synonyms: Cedar oil; cedarwood oil; oil of cedarwood; red cedarwood oil 
Summary of Findings Considered to be Toxicologically Relevant in Rats and Mice Administered Cedarwood Oil Dermally for Three Months ${ }^{a}$

\begin{tabular}{|c|c|c|c|c|}
\hline & $\begin{array}{c}\text { Male } \\
\text { F344/N Rats }\end{array}$ & $\begin{array}{c}\text { Female } \\
\text { F344/N Rats }\end{array}$ & $\begin{array}{c}\text { Male } \\
\text { B6C3F1/N Mice }\end{array}$ & $\begin{array}{c}\text { Female } \\
\text { B6C3F1/N Mice }\end{array}$ \\
\hline $\begin{array}{l}\text { Concentrations by } \\
\text { dermal application }\end{array}$ & $\begin{array}{l}0 \% \text { (UC), } 0 \% \text { (VC), } \\
6.25 \%, 12.5 \%, 25 \% \text {, } \\
50 \% \text {, or } 100 \%\end{array}$ & $\begin{array}{l}0 \% \text { (UC), } 0 \% \\
\text { (VC), } 6.25 \% \text {, } \\
12.5 \%, 25 \%, 50 \% \text {, } \\
\text { or } 100 \%\end{array}$ & $\begin{array}{l}0 \% \text { (UC), } 0 \% \text { (VC), } \\
6.25 \%, 12.5 \%, 25 \% \text {, } \\
50 \% \text {, or } 100 \%\end{array}$ & $\begin{array}{l}0 \% \text { (UC), } 0 \% \text { (VC), } \\
6.25 \%, 12.5 \%, 25 \% \text {, } \\
50 \% \text {, or } 100 \%\end{array}$ \\
\hline Survival rates & $\begin{array}{l}10 / 10,10 / 10,10 / 10 \\
10 / 10,10 / 10,10 / 10 \\
8 / 10\end{array}$ & $\begin{array}{l}\text { 10/10, 10/10, } \\
10 / 10,10 / 10 \\
10 / 10,10 / 10,10 / 10\end{array}$ & $\begin{array}{l}\text { 10/10, 10/10, 10/10, } \\
9 / 10,10 / 10,9 / 10 \\
0 / 10^{c}\end{array}$ & $\begin{array}{l}\text { 10/10, 10/10, 10/10, } \\
10 / 10,10 / 10,9 / 10 \\
0 / 10^{c}\end{array}$ \\
\hline Body weights & $\begin{array}{l}50 \% \text { group } 9 \% \text { less } \\
\text { than the vehicle } \\
\text { control group; } 100 \% \\
\text { group } 14 \% \text { less than } \\
\text { the untreated control } \\
\text { group }\end{array}$ & $\begin{array}{l}50 \% \text { group } 8 \% \text { less } \\
\text { than the vehicle } \\
\text { control group; } \\
100 \% \text { group } 11 \% \\
\text { less than the } \\
\text { untreated control } \\
\text { group }\end{array}$ & $\begin{array}{l}25 \% \text { group } 10 \% \text { less } \\
\text { than the vehicle } \\
\text { control group; } 50 \% \\
\text { group } 14 \% \text { less than } \\
\text { the vehicle control } \\
\text { group }\end{array}$ & $\begin{array}{l}12.5 \% \text { group } 12 \% \\
\text { less than the vehicle } \\
\text { control group; } 25 \% \\
\text { group } 19 \% \text { less than } \\
\text { the vehicle control } \\
\text { group; } 50 \% \text { group } \\
13 \% \text { less than the } \\
\text { vehicle control group }\end{array}$ \\
\hline Clinical observations & $\begin{array}{l}\text { Irritation, thickening, } \\
\text { and ulceration of the } \\
\text { skin at the site of } \\
\text { application }\end{array}$ & $\begin{array}{l}\text { Irritation, } \\
\text { thickening, and } \\
\text { ulceration of the } \\
\text { skin at the site of } \\
\text { application }\end{array}$ & $\begin{array}{l}\text { Irritation, thickening, } \\
\text { and ulceration of the } \\
\text { skin at the site of } \\
\text { application }\end{array}$ & $\begin{array}{l}\text { Irritation, thickening, } \\
\text { and ulceration of the } \\
\text { skin at the site of } \\
\text { application }\end{array}$ \\
\hline Organ weights & $\begin{array}{l}\uparrow \text { Liver (relative }{ }^{\mathrm{b}} \text { ) } \\
\uparrow \text { Kidney (absolute } \\
\text { and relative) } \\
\downarrow \text { Thymus (absolute) }\end{array}$ & $\begin{array}{l}\uparrow \text { Liver (absolute } \\
\text { and relative) } \\
\downarrow \text { Thymus (absolute } \\
\text { and relative) }\end{array}$ & $\begin{array}{l}\uparrow \text { Liver (absolute and } \\
\text { relative) } \\
\downarrow \text { Thymus (absolute) }\end{array}$ & $\begin{array}{l}\uparrow \text { Liver (absolute and } \\
\text { relative) } \\
\uparrow \text { Kidney (absolute } \\
\text { and relative) } \\
\downarrow \text { Thymus (absolute) }\end{array}$ \\
\hline Hematology & $\begin{array}{l}\uparrow \text { Total white blood } \\
\text { cells } \\
\uparrow \text { Neutrophil counts }\end{array}$ & $\begin{array}{l}\uparrow \text { Total white blood } \\
\text { cells } \\
\uparrow \text { Neutrophil counts }\end{array}$ & $\begin{array}{l}\uparrow \text { Neutrophil counts } \\
\downarrow \text { Hematocrit } \\
\downarrow \text { Hemoglobin } \\
\downarrow \text { Erythrocytes }\end{array}$ & $\begin{array}{l}\uparrow \text { Total white blood } \\
\text { cells } \\
\uparrow \text { Neutrophil counts } \\
\downarrow \text { Hematocrit } \\
\downarrow \text { Hemoglobin } \\
\downarrow \text { Erythrocytes }\end{array}$ \\
\hline Reproductive toxicity & None & None & None & None \\
\hline
\end{tabular}




\begin{tabular}{|c|c|c|c|c|}
\hline & $\begin{array}{c}\text { Male } \\
\text { F344/N Rats }\end{array}$ & $\begin{array}{c}\text { Female } \\
\text { F344/N Rats }\end{array}$ & $\begin{array}{c}\text { Male } \\
\text { B6C3F1/N Mice }\end{array}$ & $\begin{array}{c}\text { Female } \\
\text { B6C3F1/N Mice }\end{array}$ \\
\hline Nonneoplastic effects & 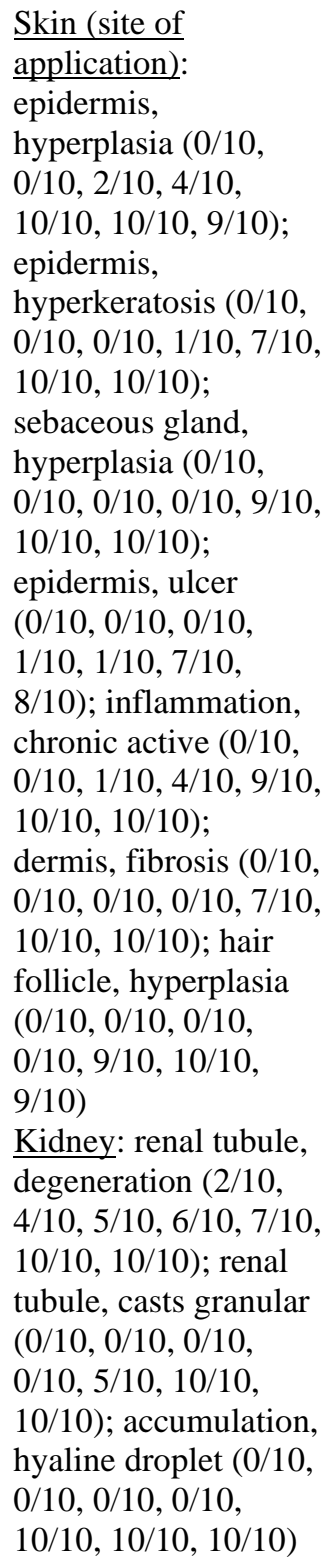 & $\begin{array}{l}\text { Skin (site of } \\
\text { application): } \\
\text { epidermis, } \\
\text { hyperplasia }(0 / 10, \\
\text { 0/10, 4/10, 7/10, } \\
\text { 10/10, 10/10, } \\
\text { 10/10); epidermis, } \\
\text { hyperkeratosis } \\
\text { (0/10, 0/10, 1/10, } \\
\text { 5/10, 10/10, 10/10, } \\
\text { 10/10); sebaceous } \\
\text { gland, hyperplasia } \\
\text { (0/10, 0/10, 0/10, } \\
\text { 4/10, 9/10, 10/10, } \\
\text { 10/10); epidermis, } \\
\text { ulcer }(0 / 10,0 / 10, \\
\text { 0/10, 1/10, 1/10, } \\
\text { 4/10, 10/10); } \\
\text { inflammation, } \\
\text { chronic active } \\
\text { (0/10, 0/10, 0/10, } \\
\text { 7/10, 10/10, 10/10, } \\
\text { 10/10); dermis, } \\
\text { fibrosis }(0 / 10,0 / 10, \\
\text { 0/10, 1/10, 7/10, } \\
\text { 8/10, 10/10); hair } \\
\text { follicle, hyperplasia } \\
(0 / 10,0 / 10,0 / 10, \\
\text { 1/10, 9/10, 10/10, } \\
\text { 10/10) } \\
\end{array}$ & $\begin{array}{l}\text { Skin (site of } \\
\text { application): } \\
\text { epidermis, } \\
\text { hyperplasia }(0 / 10, \\
\text { 0/9, 10/10, 10/10, } \\
\text { 10/10, 10/10, 10/10); } \\
\text { epidermis, } \\
\text { hyperkeratosis (0/10, } \\
\text { 0/9, 7/10, 10/10, } \\
\text { 10/10, 10/10, 10/10); } \\
\text { epidermis, ulcer } \\
\text { (0/10, 0/9, 2/10, } \\
\text { 8/10, 10/10, 9/10, } \\
\text { 10/10); } \\
\text { inflammation, } \\
\text { chronic active }(0 / 10, \\
\text { 0/9, 10/10, 10/10, } \\
\text { 10/10, 10/10, 10/10); } \\
\text { dermis, fibrosis } \\
\text { (0/10, 0/9, 3/10, } \\
\text { 10/10, 10/10, 10/10, } \\
\text { 10/10); hair follicle, } \\
\text { hyperplasia (0/10, } \\
\text { 0/9, 10/10, 10/10, } \\
\text { 10/10, 10/10, 10/10); } \\
\text { sebaceous gland, } \\
\text { hyperplasia }(0 / 10, \\
\text { 0/9, 10/10, 10/10, } \\
\text { 10/10, 10/10, 10/10) } \\
\text { Kidney: nephropathy } \\
\text { (0/10, 2/10, 0/10, } \\
\text { 1/10, 2/10, 3/10, } \\
\text { 5/10) }\end{array}$ & 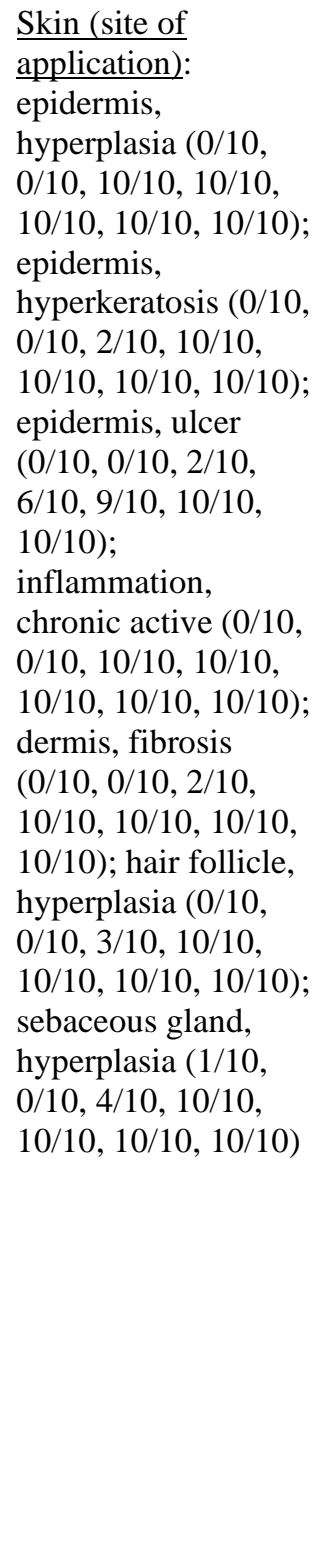 \\
\hline
\end{tabular}

\section{Genetic toxicology}

Bacterial gene mutations

Negative in S. typhimurium strains TA98, TA100, and TA102 with and without S9

Micronucleated erythrocytes

Mouse peripheral blood in vivo:

Negative in males and equivocal in females

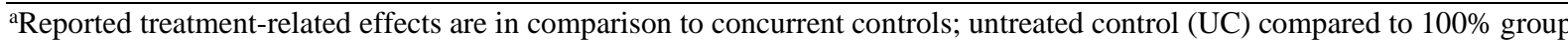
and ethanol vehicle control (VC) compared to all other dosed groups.

belative to body weight.

'Due to the severity of skin lesions, all 100\% mice were euthanized during week 10. 


\section{Introduction}
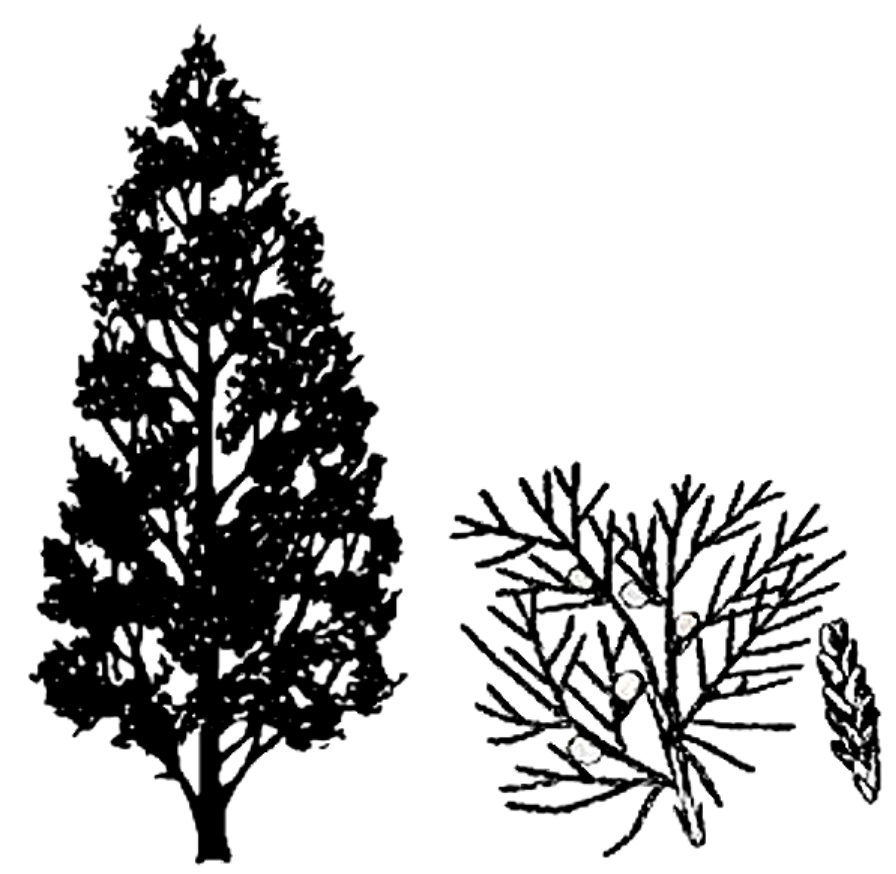

Figure 1. Virginia Cedarwood Oil (CASRN 8000-27-9)

Synonyms: Cedar oil; cedarwood oil; oil of cedarwood; red cedarwood oil.

\section{Chemical and Physical Properties}

Cedarwood oils can be extracted from several members of the Cupressaceae family, which encompasses true cedars, junipers, and cypresses. The three most prevalent cedarwood oil products in the United States are Virginia cedarwood oil (Juniperus virginiana), Texas cedarwood oil (Juniperus mexicana or Juniperus ashei), and Western red cedar (Thuja plicata) ${ }^{1}$. Western red cedar is the least commonly used of the three ${ }^{2 ;}$.

The most common components of cedarwood oils are sesquiterpene hydrocarbons and include cedrol, $\alpha$-cedrene, cedrenol, cedral, cuparene, thujopsene, and widdrol, though the relative percentages can differ depending on the origin of the cedar trees ${ }^{4-8}$. The International Organization for Standardization set the following minimum and maximum standards for the components that make up the chromatographic profile of cedarwood oil (from Juniperus virginiana): $\alpha$-cedrene ( $20 \%$ to $35 \%$ ), $\beta$-cedrene ( $4 \%$ to $8 \%$ ), thujopsene ( $10 \%$ to $25 \%$ ), cuparene (1.5\% to $7 \%$ ), cedrol (16\% to $25 \%)$, and widdrol (2\% to $5 \%)^{9}$.

Cedarwood oil is a colorless to pale brown viscous liquid with a cedarwood odor and bitter taste $^{4 ; 5}$. It is insoluble in water but soluble in ethanol or ether ${ }^{10}$ and may solidify at room temperature ${ }^{5}$. 


\section{Production, Use, and Human Exposure}

Virginia cedarwood oil is extracted from Juniperus virginiana trees by steam distillation ${ }^{5}$. Cedarwood oil of unspecified origin is used commonly in fragrance formulations, and production for this purpose exceeds 100,000 pounds per year ${ }^{5 ;}{ }^{11}$. Several cedarwood oil components can be isolated and acetylated for use in fragrances. Of the chemical components that make up cedarwood oil, cedrene, thujopsene, and cedrol are commonly isolated and often acetylated in the production of fragrance materials such as cedryl acetate and cedryl methylether ${ }^{5}$. These extracts can be found in many cosmetic products (i.e., perfumes, lotions) that may be applied to most parts of the body and may come into contact with the ocular and nasal mucosae. Frequent application of these products on a daily basis leads to long-term chronic exposure. The cosmetics industry no longer reports concentration of use values to the United States Food and Drug Administration $^{12}$. However, data submitted to the FDA indicated that the maximum use concentration ranges from the 1984 product formulation data for Juniper Extract and Juniper Tar in cosmetics were $0.1 \%$ to $1 \%$, and $1 \%$ to $5 \%$, respectively ${ }^{13}$. Limited or no toxicity was found in rats and rabbits following dermal application of either Western juniper oil $(0.5 \%, 5 \%$, or $50 \%)$ or Port-Orford cedar extract $(0.5 \%, 5 \%$, or $50 \%)$ when tested using a local lymph node assay and an acute dermal irritation study ${ }^{14}$.

As a pesticide, cedarwood oil is used as an insect repellent in sunscreens, pet collars, and for horses $^{15}$. The potential use of cedarwood oil as a topical mosquito repellent was explored, but found to be ineffective against multiple mosquito species ${ }^{16 ;}$. However, it was found to be effective with an average knock-down range of $20 \%$ to $80 \%$ when applied directly to mosquitoes, cockroaches, and houseflies ${ }^{18}$. Virginia cedarwood oil was also found to be effective as a barrier repellent to red imported fire ants and black-legged tick nymphs ${ }^{19}$. Additionally, it is used in blocks and as a liquid spray for repelling moths and mildew from clothing and fabrics ${ }^{6}$; ${ }^{15}$. In vitro, Japanese cedarwood oils have been found to have anti-fungal properties against Trichophyton rubrum through the inhibition of DNA polymerase ${ }^{20}$.

Historically, in ancient Rome and in early America, cedarwood oil was taken orally to induce abortion $^{10 ; 21 ; 22}$. Data on current human use of cedarwood oil as an abortifacient are minimal. However, exposure to the bark, leaves, and berries of western juniper trees (Juniperus occidentalis) has been shown to induce abortions in late-term cattle in Oregon ${ }^{23}$.

Based on the 1981 to 1983 National Occupational Exposure Survey, cedarwood oil was used in 7,990 facilities, and 117,858 employees were exposed to cedarwood oil ${ }^{24}$. From this NIOSH report, the scope of occupational facilities in which cedarwood oil is used is large and includes industrial settings, medical fields, and esthetics and beauty care.

\section{Regulatory Status}

Cedarwood oil alcohols and terpenes are listed as synthetic flavoring substances and adjuvants that are permitted by the United States Food and Drug Administration ${ }^{25}$ for direct addition to food for human consumption. Cedarwood oil was registered as a pesticide in the United States in $1960^{6}$. Currently, cedarwood oil is listed as a minimum risk pesticide and exempted from the Federal Insecticide, Fungicide, and Rodenticide Act regulations ${ }^{26}$. Cedarwood oil is listed in the Toxic Substances Control Act Inventory ${ }^{27}$. However, no limits on recommended or permissible exposures are available. 


\section{Absorption, Distribution, Metabolism, and Excretion}

There are very limited data in the literature on the disposition of cedarwood oil and its components. Following gavage administration of 25 (males only), 50 (females only), or 100 $\mathrm{mg} / \mathrm{kg} \alpha$-cedrene to male and female Sprague Dawley rats, the chemical was absorbed slowly with a $\mathrm{T}_{\max }$ between 2.8 and 4.4 hours $^{28 ; 29}$. The values estimated for absolute bioavailability were 42\% (males, $25 \mathrm{mg} / \mathrm{kg}$ ), 49\% (females, $50 \mathrm{mg} / \mathrm{kg}$ ), 71\% (female, $100 \mathrm{mg} / \mathrm{kg}$ ), or 85\% (male, $100 \mathrm{mg} / \mathrm{kg}$ ). Tissue distribution was investigated only in female rats, and $\alpha$-cedrene was extensively distributed to tissues with tissue:plasma ratios greater than 1 for all tissues with lipid showing the highest tissue:plasma ratio. Plasma elimination half-life was between 2 and 5.9 hours depending on the study ${ }^{28 ; 29}$. In females, $\mathrm{C}_{\max }$ and AUC values increased proportionally to the dose ${ }^{29}$. There were no sex- or dose-related differences in the disposition of $\alpha$-cedrene. The urinary excretion of unmetabolized $\alpha$-cedrene following gavage administration was equal to or less than $0.017 \%$.

\section{Toxicity}

\section{Experimental Animals}

The oral $\mathrm{LD}_{50}$ value for cedarwood oil is greater than $5 \mathrm{~g} / \mathrm{kg}$ body weight in rats, and the dermal $\mathrm{LD}_{50}$ in rabbits is also greater than $5 \mathrm{~g} / \mathrm{kg}^{11}$.

\section{Humans}

Virginia cedarwood oil (1\% or 5\%) in petrolatum was applied to 95 human patch test subjects and no skin irritation was seen on days 3 or $4^{30}$. Furthermore, several additional studies in humans have shown similar results with no skin irritation effects after Virginia cedarwood oil was topically applied to the skin over periods from 24 hours to 4 days in concentrations ranging from $0.2 \%$ to $20 \%{ }^{11 ; 31-33}$. Additional dermatologic assessments with acetyl cedrene, a common constituent of cedarwood oil, also demonstrated limited human toxicity in multiple irritation tests at concentrations up to $30 \%{ }^{34}$.

\section{Reproductive and Developmental Toxicity}

Oral exposure of pregnant Sprague Dawley rats to the cedarwood oil derivative acetyl cedrene at concentrations of 25, 50, or $100 \mathrm{mg} / \mathrm{kg}$ per day on gestation days 7 to 17 resulted in no significant fetal effects and minor maternal effects such as decreased body weight gains and feed consumption; the no-observed-adverse-effect levels were 50 and $100 \mathrm{mg} / \mathrm{kg}$ per day for the dams and fetuses, respectively ${ }^{35}$. In a separate study, $\beta$-thujaplicin (another cedarwood oil derivative) was orally administered to pregnant ICR mice on gestation day 9; evaluation of the fetuses on gestation day 18 found that the chemical induced several malformations at doses of $560 \mathrm{mg} / \mathrm{kg}$ or greater, including cleft lip, cleft palate, and facial dysmorphism ${ }^{36}$.

\section{Carcinogenicity}

No information on the carcinogenicity of cedarwood oil in experimental animals or humans was found in a review of the literature. 


\section{Genetic Toxicity}

No information on the genotoxicity of cedarwood oil was found in the literature.

\section{Study Rationale}

Cedarwood oil was nominated for study by the National Cancer Institute based on widespread and increasing human exposure to the substance and a lack of toxicology data. Due to the frequent use of cedarwood oil as a fragrance material and a pesticide, the dermal route of administration was selected for these studies because it is the most common route of exposure in humans. 


\section{Materials and Methods}

\section{Procurement and Characterization}

\section{Virginia Cedarwood Oil}

Prior to selecting the test article, NTP investigated the composition of selected components in six lots that were procured as Virginia cedarwood oil from three suppliers. The chromatographic profiles of the six lots were similar to each other. The composition of $\alpha$-cedrene, $\beta$-cedrene, thujopsene, cuparene, and cedrol in these lots ranged from $18 \%$ to $40 \%, 4 \%$ to $8 \%, 16 \%$ to $31 \%$, $2 \%$ to $4 \%$, and $19 \%$ to $26 \%$, respectively. Due to the close similarities between the procured lots, the lot selected for testing was based upon the availability in bulk quantity.

For the current 3-month dermal studies, Virginia cedarwood oil was obtained from Texarome, Inc. (Leakey, TX), in one lot (T122303DP). Identity, purity, and stability analyses were conducted by the analytical chemistry laboratory at Midwest Research Institute (Kansas City, $\mathrm{MO}$ ) and the study laboratory at Battelle Columbus Operations (Columbus, OH) (Appendix F). Reports on analyses performed in support of the cedarwood oil studies are on file at the National Institute of Environmental Health Sciences.

The chemical, a pale yellow oily liquid with a cedar odor, was identified as cedarwood oil using infrared (IR) and proton nuclear magnetic resonance (NMR) spectroscopy.

Physical properties for lot T122303DP were determined by the analytical chemistry laboratory; optical rotation was $-26.1^{\circ}$ and specific gravity was 0.9581 at $24.8^{\circ} \mathrm{C}$, refractive index was 1.5053 at $19^{\circ} \mathrm{C}$, and viscosity was $22.6 \mathrm{cP}$ at $22.2^{\circ} \mathrm{C}$. The determined values for optical rotation, specific gravity, and refractive index were consistent with the reported values for cedarwood $\mathrm{oil}^{37}$.

The purity of lot T122303DP was determined based on a chromatography profile of the major components obtained by using gas chromatography (GC) with flame ionization detection (FID). Five compounds ( $\alpha$-cedrene, $\beta$-cedrene, thujopsene, cuparene, and cedrol) were selected as marker compounds and quantitated using standards obtained from Sigma-Aldrich Corporation (St. Louis, MO); the percentages were 27.01\% $\alpha$-cedrene, 6.05\% $\beta$-cedrene, 19.64\% thujopsene, $0.96 \%$ cuparene, and $21.83 \%$ cedrol. The components of lot T122303DP were also determined using GC with mass spectrometry (MS) detection. Ten marker compounds having peak areas of at least $1 \%$ of the total peak area were identified in this analysis: $\alpha$-cedrene, $\beta$-cedrene, thujopsene, $\beta$-chamigrene, $\alpha$-alaskene, $\alpha$-cuprenene, $\beta$-himachalene, cuparene, cedrol, and widdrol. Headspace analyses for volatiles were conducted on samples of this lot using GC/MS both before and after homogenization at $50^{\circ} \mathrm{C}$, and 15 components were identified in the chromatographic profiles; limonene (or an isomer), iso-italicene (or an isomer), italicene (or an isomer), $\alpha$-cedrene, cis- $\beta$-farnesene (or an isomer), $\beta$-selinene (or an isomer), $\beta$-cedrene, thujopsene, $\beta$-chamigrene (or an isomer), $\alpha$-alaskene (or an isomer), $\alpha$-cuprenene (or an isomer), $\beta$-himachalene (or an isomer), cuparene, cedrol, and widdrol. No significant differences were observed between samples analyzed before and after homogenization. Taken together, the results of these characterization assays indicated that the composition of lot T122303DP was consistent with that reported in the literature for cedarwood oil ${ }^{37-39}$. 
Stability studies of the bulk chemical were performed for samples stored at $-20^{\circ}, 5^{\circ}, 25^{\circ}$, or $60^{\circ} \mathrm{C}$ in sealed amber glass vials; additional freeze/thaw analyses were also performed every 2 to 3 days during the 2 -week stability studies. Stability was confirmed for at least 2 weeks for samples stored at temperatures up to $25^{\circ} \mathrm{C}$ in sealed amber glass vials. Freeze/thaw analyses indicated no decomposition due to repeated freezing and thawing.

To ensure stability, the bulk chemical was stored at approximately $25^{\circ} \mathrm{C}$ in the original sealed amber glass shipping bottles. Periodic reanalyses of the bulk chemical were performed during the 3-month studies using GC/FID and no degradation of the bulk chemical was detected.

\section{Ethanol}

USP grade 95\% ethanol was obtained from Spectrum Chemicals \& Laboratory Products (Gardena, CA) in one lot (TP0179) and from AAPER Alcohol (Shelbyville, KY) in one lot (02K2JWB). Lot TP0179 was used in the 3-month dermal studies, and lot 02K2JWB was used in the dose formulation stability studies.

\section{Preparation and Analysis of Dose Formulations}

The dose formulations were prepared four times by mixing cedarwood oil and 95\% ethanol to give the required concentrations (Table F-2). The dose formulations were stored at approximately $25^{\circ} \mathrm{C}$ in amber glass bottles sealed with Teflon ${ }^{\circledR}$-lined lids for up to 34 days.

Homogeneity and stability studies of a $9.5 \mathrm{mg} / \mathrm{mL}$ (0.95\%) formulation in 95\% ethanol were performed by the analytical chemistry laboratory using GC/FID. Based on these studies, homogeneity was confirmed and stability was confirmed for cedarwood oil formulations stored in amber glass containers sealed with Teflon ${ }^{\circledR}$-lined lids for 1 day with expected losses of $6.2 \%$ or less for all components or stored for 42 days with expected losses of $10.4 \%$ or less. Cedarwood oil formulations were stable for up to 3 hours under simulated animal room conditions.

Periodic analyses of the dose formulations of cedarwood oil were conducted by the study laboratory using GC/FID. During the 3-month studies, the dose formulations were analyzed three times; all 15 dose formulations analyzed for rats and all 14 dose formulations for mice were within $10 \%$ of the target concentrations (Table F-3). Animal room samples of these dose formulations were also analyzed; all 15 for rats and all 14 for mice were within $10 \%$ of the target concentrations.

\section{Animal Source}

Male and female F344/N rats and B6C3F1/N mice were obtained from the NTP colony at Taconic Farms, Inc. (Germantown, NY).

\section{Animal Welfare}

Animal care and use are in accordance with the Public Health Service Policy on Humane Care and Use of Animals. All animal studies were conducted in an animal facility accredited by the Association for the Assessment and Accreditation of Laboratory Animal Care International. Studies were approved by the Battelle Columbus Operations Animal Care and Use Committee 
and conducted in accordance with all relevant NIH and NTP animal care and use policies and applicable federal, state, and local regulations and guidelines.

\section{Three-month Studies}

On receipt, the rats and mice were 4 to 5 weeks old. Animals were quarantined for 13 or 14 days (rats) or 11 or 12 days (mice); rats were 6 to 7 weeks old and mice were 5 to 6 weeks old on the first day of dosing at the start of the studies. Before the studies began, five male and five female rats and mice were randomly selected for parasite evaluation and gross observation for evidence of disease. The health of the animals was monitored during the studies according to the protocols of the NTP Sentinel Animal Program (Appendix H). All test results were negative.

Groups of 10 male and 10 female rats and mice received no treatment (untreated control) or were administered cedarwood oil in 95\% aqueous ethanol dermally at concentrations of $0 \%$ (vehicle control), $6.25 \%, 12.5 \%, 25 \%, 50 \%$, or $100 \%$ (neat) 5 days per week for 14 weeks. Formulations were administered at a volume of $0.5 \mathrm{~mL} / \mathrm{kg}$ body weight (rats) or $2.0 \mathrm{~mL} / \mathrm{kg}$ (mice). These corresponded to applied doses of 31.25 to $500 \mathrm{mg}$ cedarwood oil/ $\mathrm{kg}$ body weight in rats and 125 to $2,000 \mathrm{mg} / \mathrm{kg}$ in mice. Doses were applied using a repeating pipette with a disposable tip to a consistent area that was shaved weekly. The shaved area was on the dorsal surface just posterior to the scapulae to the base of the tail and larger than the application site. Feed and water were available ad libitum. Rats and mice were housed individually. All animals were weighed and clinical observations were recorded initially, weekly, and at the end of the studies. Details of the study design and animal maintenance are summarized in Table 1. The feed was acceptable for use and information on feed composition and contaminants is provided in Appendix G.

Animals were anesthetized with a carbon dioxide/oxygen mixture, and blood was collected from the retroorbital plexus of rats and the retroorbital sinus of mice at the end of the 3-month studies for hematology analyses. Blood samples were collected in tubes containing EDTA as the anticoagulant. Parameters were measured using an ADVIA ${ }^{\circledR} 120$ Hematology Analyzer (Bayer, Inc., Tarrytown, NY) using reagents supplied by the manufacturer. The parameters measured are listed in Table 1.

At the end of the 3-month studies, samples were collected for sperm motility or vaginal cytology evaluations on male and female rats in the vehicle control, $12.5 \%, 25 \%$, and $50 \%$ groups, and male and female mice in the vehicle control, 6.25\%, $12.5 \%$, and $25 \%$ groups. The parameters evaluated are listed in Table 1 . For 12 consecutive days prior to scheduled terminal euthanasia, the vaginal vaults of the females were moistened with saline, if necessary, and samples of vaginal fluid and cells were stained. Relative numbers of leukocytes, nucleated epithelial cells, and large squamous epithelial cells were determined and used to ascertain estrous cycle stage (i.e., diestrus, proestrus, estrus, and metestrus). Male animals were evaluated for sperm count and motility. The left testis and left epididymis were isolated and weighed. The tail of the epididymis (cauda epididymis) was then removed from the epididymal body (corpus epididymis) and weighed. Test yolk (rats) or modified Tyrone’s buffer (mice) was applied to slides and a small incision was made at the distal border of the cauda epididymis. The sperm effluxing from the incision were dispersed in the buffer on the slides, and the numbers of motile and nonmotile spermatozoa were counted for five fields per slide by two observers. Following completion of sperm motility estimates, each left cauda epididymis was placed in buffered saline solution. Caudae were finely minced, and the tissue was incubated in the saline solution and then heat 
fixed at $65^{\circ} \mathrm{C}$. Sperm density was then determined microscopically with the aid of a hemacytometer. To quantify spermatogenesis, the testicular spermatid head count was determined by removing the tunica albuginea and homogenizing the left testis in phosphatebuffered saline containing $10 \%$ dimethyl sulfoxide. Homogenization-resistant spermatid nuclei were counted with a hemacytometer.

Necropsies were performed on all rats and mice. The heart, right kidney, liver, lung, right testis, and thymus were weighed. Tissues for microscopic examination were fixed and preserved in $10 \%$ neutral buffered formalin (eyes were first fixed in Davidson's solution), processed and trimmed, embedded in paraffin, sectioned to a thickness of 4 to $6 \mu \mathrm{m}$, and stained with hematoxylin and eosin. Additional sections of the kidney from male rats were stained with the Mallory-Heidenhain stain for protein. Complete histopathologic examinations were performed by the study laboratory pathologist on rats in the untreated control, vehicle control, and $100 \%$ groups and mice in the untreated control, vehicle control, 50\%, and $100 \%$ groups; the adrenal cortex (males), bone marrow, kidney (males only), liver, skin at the site of application, and thyroid gland of rats and the bone marrow, kidney (males only), liver, lymph nodes, skin at the site of application, spleen, and thymus of mice were examined in all remaining dosed groups. Table 1 lists the tissues and organs routinely examined.

After a review of the laboratory reports and selected histopathology slides by a quality assessment (QA) pathologist, the findings and reviewed slides were submitted to a NTP Pathology Working Group (PWG) coordinator for a second independent review. Any inconsistencies in the diagnoses made by the study laboratory and QA pathologists were resolved by the NTP pathology peer review process. Final diagnoses for reviewed lesions represent a consensus of the PWG or a consensus between the study laboratory pathologist, NTP pathologist, QA pathologist(s) and the PWG coordinator. Details of these review procedures have been described, in part, by Maronpot and Boorman ${ }^{40}$ and Boorman et al. ${ }^{41}$.

Table 1. Experimental Design and Materials and Methods in the Three-month Dermal Studies of Cedarwood Oil

Three-month Study

Study Laboratory

Battelle Columbus Operations (Columbus, $\mathrm{OH}$ )

Strain and Species

F344/N rats

B6C3F1/N mice

Animal Source

Taconic Farms, Inc. (Germantown, NY)

Time Held Before Studies

Rats: 13 (males) or 14 (females) days

Mice: 11 (females) or 12 (males) days

\section{Average Age When Studies Began}

Rats: 6 to 7 weeks

Mice: 5 to 6 weeks 


\section{Three-month Study}

\section{Date of First Dose}

Rats: June 15 (males) or 16 (females), 2005

Mice: June 13 (females) or 14 (males), 2005

Duration of Dosing

5 days per week for 14 weeks

Date of Last Dose

Rats: September 14 (males) or 15 (females), 2005

Mice: September 12 (females) or 13 (males), 2005

\section{Necropsy Dates}

Rats: September 15 (males) or 16 (females), 2005

Mice: September 13 (females) or 14 (males), 2005

\section{Average Age at Necropsy}

19 to 20 weeks

\section{Size of Study Groups}

10 males and 10 females

\section{Method of Distribution}

Animals were distributed randomly into groups of approximately equal initial mean body weights.

\section{Animals per Cage}

1

\section{Method of Animal Identification}

Tail tattoo

Diet

Irradiated NTP-2000 open formula wafer feed (Zeigler Brothers, Inc., Gardners, PA), available ad libitum, changed at least weekly

\section{Water}

Tap water (City of Columbus municipal supply) via automatic watering system (Edstrom Industries, Inc., Waterford, WI), available ad libitum

\section{Cages}

Polycarbonate [Allentown Caging Equipment Company, Allentown, NJ (rats), or Lab Products, Inc., Seaford, DE (mice)], changed weekly

\section{Bedding}

Heat-treated, irradiated hardwood Sani-Chips ${ }^{\circledR}$ (P.J. Murphy Forest Products Corp., Montville, NJ), changed weekly

\section{Rack Filters}

Spun-bonded polyester (Snow Filtration Company, Cincinnati, OH), changed every 2 weeks

\section{Racks}

Stainless steel (Lab Products, Inc., Seaford, DE), changed every 2 weeks 


\title{
Three-month Study
}

\author{
Animal Room Environment \\ Temperature: $72^{\circ} \pm 3^{\circ} \mathrm{F}$ \\ Relative humidity: $50 \% \pm 15 \%$ \\ Room fluorescent light: 12 hours/day \\ Room air changes: 10/hour
}

\section{Concentrations}

Untreated control, 0\% (vehicle control), 6.25\%, 12.5\%, 25\%, 50\%, or 100\% (neat)

\section{Type and Frequency of Observation}

Observed twice daily; animals were weighed and clinical observations were recorded initially, weekly thereafter, and at the end of the studies.

\section{Method of Euthanasia}

Carbon dioxide asphyxiation

\section{Necropsy}

Necropsies were performed on all animals. Organs weighed were heart, right kidney, liver, lung, right testis, and thymus.

\section{Clinical Pathology}

Blood was collected from the retroorbital plexus of rats and the retroorbital sinus of mice at the end of the studies for hematology.

Hematology: hematocrit; hemoglobin; erythrocyte, reticulocyte, and platelet counts; mean cell volume; mean cell hemoglobin; mean cell hemoglobin concentration; and leukocyte count and differentials

\section{Histopathology}

Complete histopathology was performed on rats in the untreated control, vehicle control, and $100 \%$ groups and mice in the untreated control, vehicle control, 50\%, and 100\% groups. In addition to gross lesions and tissue masses, the following tissues were examined: adrenal gland, bone with marrow, brain, clitoral gland, esophagus, eye, gallbladder (mice), Harderian gland, heart and aorta, large intestine (cecum, colon, rectum), small intestine (duodenum, jejunum, ileum), kidney, liver, lung (with mainstem bronchus), lymph nodes (mandibular and mesenteric), mammary gland, nose, ovary, pancreas, parathyroid gland, pituitary gland, preputial gland, prostate gland, salivary gland, seminal vesicle, skin (site of application), spleen, stomach (forestomach and glandular), testis (with epididymis), thymus, thyroid gland, trachea, urinary bladder, and uterus. The adrenal cortex (males), bone marrow, kidney (males), liver, skin at the site of application, and thyroid gland of rats and the bone marrow, kidney (males), liver, lymph nodes, skin the site of application, spleen, and thymus of mice were examined in the remaining dosed groups.

\section{Sperm Motility and Vaginal Cytology}

At the end of the studies, sperm samples were collected from male rats in the vehicle control, $12.5 \%$, 25\%, and $50 \%$ groups and male mice in the vehicle control, 6.25\%, 12.5\%, and 25\% groups for sperm motility evaluations. The following parameters were evaluated: spermatid heads per testis and per gram testis, and epididymal spermatozoal motility and concentration. The left cauda, left epididymis, and left testis were weighed. Vaginal samples were collected for up to 12 consecutive days prior to the end of the studies from female rats in the vehicle control, $12.5 \%, 25 \%$, and 50\% groups and female mice in the vehicle control, $6.25 \%, 12.5 \%$, and $25 \%$ groups for vaginal cytology evaluations. 


\section{Statistical Methods}

Responses at concentrations up to 50\% were compared to those of the vehicle control group; responses at $100 \%$ were compared to those of the untreated control group. In addition, vehicle control groups were compared to untreated control groups for selected rat data.

\section{Calculation and Analysis of Lesion Incidences}

The incidences of lesions are presented in Appendix A as the numbers of animals bearing such lesions at a specific anatomic site and the numbers of animals with that site examined microscopically. The Fisher exact test ${ }^{42}$, a procedure based on the overall proportion of affected animals, was used to determine significance between dosed and untreated control or vehicle control animals.

\section{Analysis of Continuous Variables}

For dosed groups compared to the vehicle control groups, two approaches were employed to assess the significance of pairwise comparisons in the analysis of continuous variables. Organ and body weight data, which historically have approximately normal distributions, were analyzed with the parametric multiple comparison procedures of Dunnett ${ }^{43}$ and Williams ${ }^{44 ; 45}$. Hematology, spermatid, and epididymal spermatozoal data, which have typically skewed distributions, were analyzed using the nonparametric multiple comparison methods of Shirley ${ }^{46}$ (as modified by Williams ${ }^{47}$ ) and Dunn $^{48}$. Jonckheere's test ${ }^{49}$ was used to assess the significance of the dose-related trends and to determine whether a trend-sensitive test (Williams' or Shirley's test) was more appropriate for pairwise comparisons than a test that does not assume a monotonic dose-related trend (Dunnett's or Dunn's test). Prior to statistical analysis, extreme values identified by the outlier test of Dixon and Massey ${ }^{50}$ were examined by NTP personnel, and implausible values were eliminated from the analysis. Proportions of regular cycling females in each dosed group were compared to the vehicle control group using the Fisher exact test ${ }^{42}$. Tests for extended periods of estrus, diestrus, metestrus, and proestrus, as well as skipped estrus and skipped diestrus, were constructed based on a Markov chain model proposed by Girard and Sager $^{51}$. For each dose group, a transition probability matrix was estimated for transitions among the proestrus, estrus, metestrus, and diestrus stages, with provision for extended stays within each stage as well as for skipping estrus or diestrus within a cycle. Equality of transition matrices among dose groups and between the vehicle control group and each dosed group was tested using chi-square statistics.

For comparison of the $100 \%$ (neat) groups to the untreated control groups, a $t$-test was used to determine significant differences in organ and body weight data for rats, and a Wilcoxon's rank sum test was used for hematology data for rats ${ }^{52}$.

\section{Quality Assurance Methods}

The 3-month studies were conducted in compliance with Food and Drug Administration Good Laboratory Practice Regulations ${ }^{53}$. In addition, as records from the 3-month studies were submitted to the NTP Archives, these studies were audited retrospectively by an independent QA contractor. Separate audits covered completeness and accuracy of the pathology data, pathology specimens, final pathology tables, and a draft of this NTP Toxicity Study Report. Audit procedures and findings are presented in the reports and are on file at NIEHS. The audit findings 
were reviewed and assessed by NTP staff, and all comments were resolved or otherwise addressed during the preparation of this Toxicity Study Report.

\section{Genetic Toxicology}

\section{Salmonella typhimurium Mutagenicity Test Protocol}

Testing procedures used for cedarwood oil followed protocols reported by Zeiger et al. ${ }^{54}$. Cedarwood oil was sent to the laboratory as a coded sample. It was incubated with the Salmonella typhimurium tester strains TA98, TA100, and TA102 either in buffer or S9 mix (metabolic activation enzymes and cofactors from Aroclor 1254-induced male Sprague-Dawley rats) for 20 minutes at $37^{\circ} \mathrm{C}$. Top agar supplemented with L-histidine and D-biotin was added, and the contents of the tubes were mixed and poured onto the surfaces of minimal glucose agar plates. Histidine-independent mutant colonies arising on these plates were counted following incubation for 2 days at $37^{\circ} \mathrm{C}$.

Each trial consisted of triplicate plates of concurrent positive and negative controls and of at least five doses of cedarwood oil. The high dose was limited by toxicity to $33 \mu \mathrm{g} /$ plate without S9 mix and $333 \mu \mathrm{g} /$ plate with S9.

In this assay, a positive response is defined as a reproducible, dose-related increase in histidineindependent (revertant) colonies in any one strain/activation combination. An equivocal response is defined as an increase in revertants that is not dose related, is not reproducible, or is not of sufficient magnitude to support a determination of mutagenicity. A negative response is obtained when no increase in revertant colonies is observed following chemical treatment. There is no minimum percentage or fold increase required for a chemical to be judged positive or weakly positive, although positive calls are typically reserved for increases in mutant colonies that are at least twofold over background.

\section{Mouse Peripheral Blood Micronucleus Test Protocol}

A detailed discussion of this assay is presented by MacGregor et al. ${ }^{55}$. At the termination of the 3-month study, peripheral blood samples were obtained from male and female mice. Smears were immediately prepared and fixed in absolute methanol. The methanol-fixed slides were stained with acridine orange and coded. Slides were scanned to determine the frequency of micronucleated cells in 2,000 normochromatic erythrocytes (NCEs) in each of five animals per dose group. In addition, the percentage of polychromatic erythrocytes (PCEs) in a population of 1,000 erythrocytes was determined as a measure of bone marrow toxicity.

The results were tabulated as the mean of the pooled results from all animals within a treatment group, plus or minus the standard error of the mean. The frequency of micronucleated cells among NCEs was analyzed by a statistical software package that tested for increasing trend over dose groups using a one-tailed Cochran-Armitage trend test, followed by pairwise comparisons between each dosed group and the vehicle control group. In the presence of excess binomial variation, as detected by a binomial dispersion test, the binomial variance of the CochranArmitage test was adjusted upward in proportion to the excess variation. In the micronucleus test, an individual trial is considered positive if the trend test $\mathrm{P}$ value is less than or equal to 0.025 and the $\mathrm{P}$ value for any single dosed group is less than or equal to 0.025 divided by the number of dosed groups. Trials with either a significant trend or a significant dose are judged to 
be equivocal. The absence of a trend and a significant dose results in a negative call. Ultimately, the scientific staff determines the final call after considering the results of statistical analyses, reproducibility of any effects observed, and the magnitudes of those effects.

\section{Evaluation Protocol}

These are the basic guidelines for arriving at an overall assay result for assays performed by the National Toxicology Program. Statistical as well as biological factors are considered. For an individual assay, the statistical procedures for data analysis have been described in the preceding protocols. There have been instances, however, in which multiple samples of a chemical were tested in the same assay, and different results were obtained among these samples and/or among laboratories. Results from more than one aliquot or from more than one laboratory are not simply combined into an overall result. Rather, all the data are critically evaluated, particularly with regard to pertinent protocol variations, in determining the weight-of-evidence for an overall conclusion of chemical activity in an assay. In addition to multiple aliquots, the in vitro assays have another variable that must be considered in arriving at an overall test result. In vitro assays are conducted with and without exogenous metabolic activation. Results obtained in the absence of activation are not combined with results obtained in the presence of activation; each testing condition is evaluated separately. The results presented in the Abstract of this Toxicity Report represent a scientific judgment of the overall evidence for activity of the chemical in an assay. 


\section{Results}

\section{Three-month Study in Rats}

With the exceptions of two males in the $100 \%$ group, which were removed due to severe skin lesions, all rats survived to the end of the study (Table 2). Final mean body weights and body weight gains of $50 \%$ and $100 \%$ males and females were significantly less than those of their respective control groups and the mean body weight gain of male rats in the 25\% group was significantly less than that of the vehicle control group (Table 2 and Figure 2). Test articlerelated clinical observations included irritation, thickening, and ulceration of the skin at the site of application in most males in the $25 \%$ or greater groups and most females in the $12.5 \%$ or greater groups.

The hematology data for rats are presented in Table B-1. There was a small (30\% to 40\%) increase in the total white blood cell counts of 50\% females and the $100 \%$ groups of both sexes. The increased leukon was characterized most consistently by two-to three-fold increases in neutrophil counts, and to a lesser extent, increases in monocyte counts in the $100 \%$ male and female groups. Neutrophil counts were also minimally increased (30\% to 40\%) in the 50\% male and female groups. A minimal decrease in erythron (5\%) was evidenced by small decreases in the hematocrit value and hemoglobin concentration of $100 \%$ females and the erythrocyte count of $100 \%$ males.

There were no changes in the number of sperm or spermatids, sperm motility, or testis and epididymis weights of dosed males (Table D-1). There were no estrous cycle changes in dosed females (Table D-2, Table D-3; Figure D-1). Under the conditions of this study, cedarwood oil applied dermally did not exhibit the potential to be a reproductive toxicant in male or female F344/N rats.

Table 2. Survival and Body Weights of Rats in the Three-month Dermal Study of Cedarwood Oil ${ }^{\mathrm{a}}$

\begin{tabular}{|c|c|c|c|c|c|}
\hline $\begin{array}{c}\text { Concentration } \\
(\%)\end{array}$ & Survival $^{\mathbf{b}}$ & $\begin{array}{l}\text { Initial Body } \\
\text { Weight } \\
\text { (g) }\end{array}$ & $\begin{array}{l}\text { Final Body } \\
\text { Weight } \\
\text { (g) }\end{array}$ & $\begin{array}{l}\text { Change in Body } \\
\text { Weight } \\
\text { (g) }\end{array}$ & $\begin{array}{c}\text { Final Weight } \\
\text { Relative } \\
\text { to Controls } \\
(\%)\end{array}$ \\
\hline \multicolumn{6}{|l|}{ Male } \\
\hline Untreated Control & $10 / 10$ & $113 \pm 2$ & $323 \pm 4$ & $209 \pm 3$ & \\
\hline Vehicle Control & $10 / 10$ & $114 \pm 2$ & $329 \pm 4$ & $215 \pm 4$ & \\
\hline 6.25 & $10 / 10$ & $114 \pm 2$ & $318 \pm 5$ & $204 \pm 4$ & 97 \\
\hline 12.5 & $10 / 10$ & $113 \pm 2$ & $316 \pm 6$ & $203 \pm 5$ & 96 \\
\hline 25 & $10 / 10$ & $114 \pm 2$ & $308 \pm 10$ & $195 \pm 8^{*}$ & 94 \\
\hline 50 & $10 / 10$ & $113 \pm 2$ & $301 \pm 8^{*}$ & $188 \pm 8^{* *}$ & 92 \\
\hline 100 & $8 / 10^{\mathrm{d}}$ & $115 \pm 2$ & $279 \pm 7 \dagger †$ & $166 \pm 7 \dagger \dagger$ & 87 \\
\hline \multicolumn{6}{|l|}{ Female } \\
\hline Untreated Control & $10 / 10$ & $102 \pm 1$ & $200 \pm 4$ & $98 \pm 4$ & \\
\hline Vehicle Control & $10 / 10$ & $103 \pm 2$ & $197 \pm 2$ & $94 \pm 2$ & \\
\hline
\end{tabular}




\section{Cedarwood Oil, NTP TOX 86}

\begin{tabular}{cccccc}
\hline $\begin{array}{c}\text { Concentration } \\
(\%)\end{array}$ & Survival & $\begin{array}{c}\text { Initial Body } \\
\text { Weight } \\
\text { (g) }\end{array}$ & $\begin{array}{c}\text { Final Body } \\
\text { Weight } \\
\text { (g) }\end{array}$ & $\begin{array}{c}\text { Change in Body } \\
\text { Weight } \\
\text { (g) }\end{array}$ & $\begin{array}{c}\text { Final Weight } \\
\text { Relative } \\
\text { to Controls } \\
\text { (\%) }\end{array}$ \\
\hline 6.25 & $10 / 10$ & $102 \pm 2$ & $199 \pm 4$ & $97 \pm 3$ & 101 \\
12.5 & $10 / 10$ & $103 \pm 1$ & $194 \pm 5$ & $91 \pm 4$ & 98 \\
25 & $10 / 10$ & $102 \pm 1$ & $193 \pm 4$ & $91 \pm 3$ & 98 \\
50 & $10 / 10$ & $102 \pm 1$ & $182 \pm 4^{*}$ & $80 \pm 3^{* *}$ & 92 \\
100 & $10 / 10$ & $102 \pm 2$ & $179 \pm 3 \dagger \dagger$ & $78 \pm 3 \dagger \dagger$ & 90 \\
\hline
\end{tabular}

*Significantly different $(\mathrm{P} \leq 0.05)$ from the vehicle control group by Williams' or Dunnett’s test.

**P $\leq 0.01$.

$\dagger \dagger$ Significantly different $(\mathrm{P} \leq 0.01)$ from the untreated control group by a $t$-test.

${ }^{a}$ Weights and weight changes are given as mean \pm standard error.

bNumber of animals surviving at 14 weeks/number initially in group.

'Dosed groups are compared to the vehicle control groups, except $100 \%$ groups are compared to the untreated control groups.

eWeek of deaths: 12. 

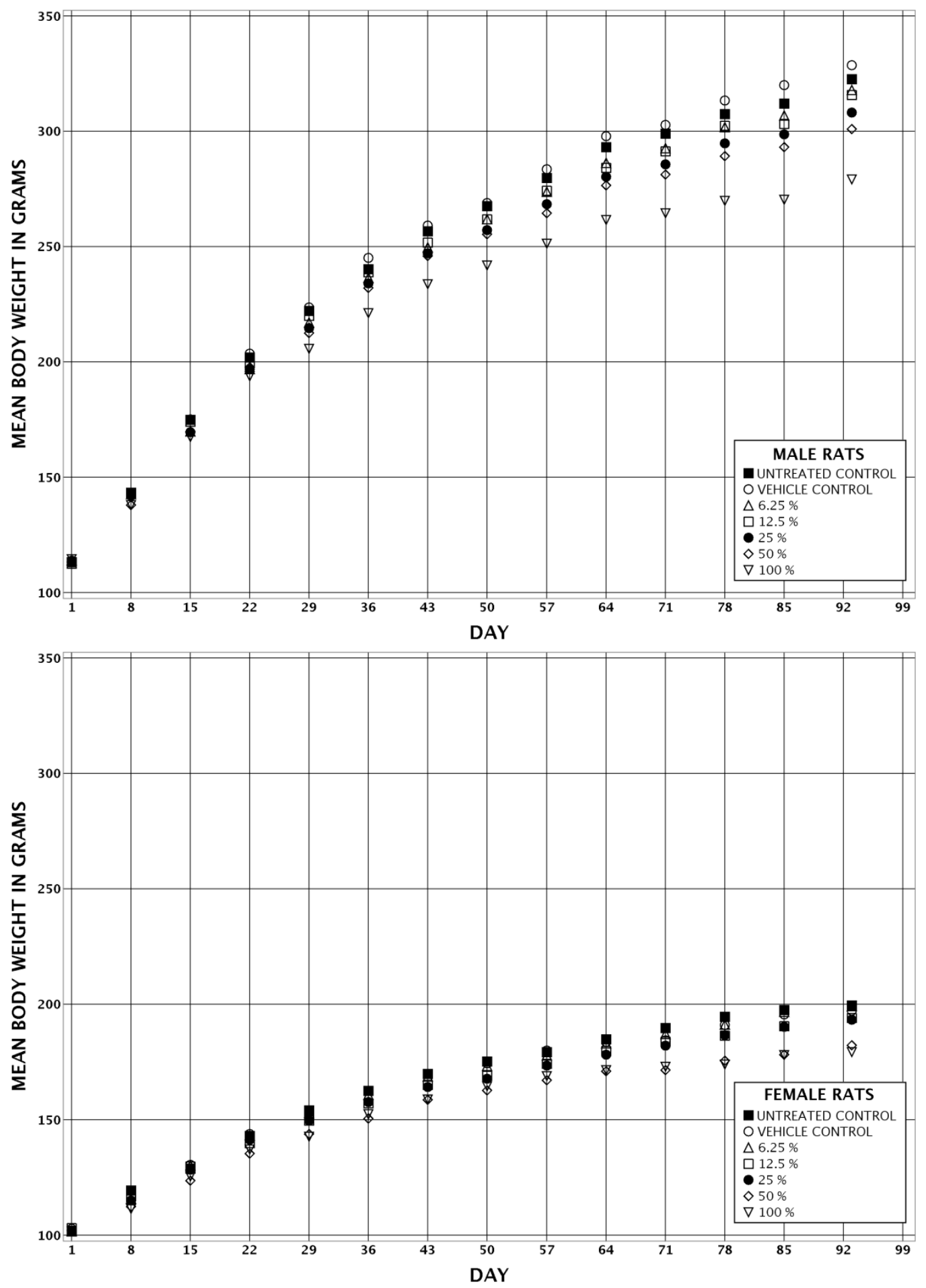

Figure 2. Growth Curves for Rats Administered Cedarwood Oil Dermally for Three Months

Relative liver weights of males in the $50 \%$ and $100 \%$ groups, and absolute and relative liver weights of females in the $100 \%$ group were significantly greater than those in the respective control groups (Table 3 and Table C-1). The absolute kidney weight of 100\% males and relative kidney weights of males in the $50 \%$ and $100 \%$ groups and females in the $25 \%$ or greater groups 


\section{Cedarwood Oil, NTP TOX 86}

were significantly greater than those in the respective control groups. However, the kidney weight changes in females are most likely attributable to overall body weight changes. The absolute thymus weights of $25 \%$ and $100 \%$ males and the absolute and relative thymus weights of $100 \%$ females were significantly less than those in the respective control groups. The organ weight changes in the liver, kidney, and thymus were not accompanied by any significant histopathologic lesions.

Table 3. Organ Weights and Organ-Weight-to-Body-Weight Ratios for Rats in the Three-month Dermal Study of Cedarwood Oil ${ }^{\text {a }}$

\begin{tabular}{|c|c|c|c|c|c|c|c|}
\hline & $\begin{array}{l}\text { Untreated } \\
\text { Control }\end{array}$ & $\begin{array}{l}\text { Vehicle } \\
\text { Control }\end{array}$ & $6.25 \%$ & $12.5 \%$ & $25 \%$ & $50 \%$ & $100 \%$ \\
\hline \multicolumn{8}{|l|}{ Male } \\
\hline n & 10 & 10 & 10 & 10 & 10 & 10 & 8 \\
\hline Necropsy body wt & $323 \pm 4$ & $329 \pm 4$ & $318 \pm 5$ & $316 \pm 6$ & $308 \pm 10$ & $301 \pm 8^{*}$ & $279 \pm 7 \dagger †$ \\
\hline \multicolumn{8}{|l|}{ R. Kidney } \\
\hline Absolute & $1.09 \pm 0.02$ & $1.15 \pm 0.02 \dagger$ & $1.08 \pm 0.03$ & $1.10 \pm 0.02$ & $1.12 \pm 0.04$ & $1.19 \pm 0.03$ & $1.33 \pm 0.05 † \dagger$ \\
\hline Relative & $3.37 \pm 0.05$ & $3.51 \pm 0.04 \dagger$ & $3.40 \pm 0.04$ & $3.50 \pm 0.07$ & $3.63 \pm 0.06$ & $3.96 \pm 0.08 * *$ & $4.77 \pm 0.11 \dagger \dagger$ \\
\hline \multicolumn{8}{|l|}{ Liver } \\
\hline Absolute & $12.42 \pm 0.37$ & $12.75 \pm 0.26$ & $12.91 \pm 0.38$ & $12.47 \pm 0.31$ & $12.60 \pm 0.49$ & $13.07 \pm 0.37$ & $13.43 \pm 0.42$ \\
\hline Relative & $38.55 \pm 1.21$ & $38.79 \pm 0.58$ & $40.58 \pm 0.97$ & $39.52 \pm 0.75$ & $40.89 \pm 0.86$ & $43.49 \pm 0.84^{* *}$ & $48.18 \pm 1.31 \dagger \dagger$ \\
\hline \multicolumn{8}{|l|}{ Thymus } \\
\hline Absolute & $0.282 \pm 0.013$ & $0.282 \pm 0.006$ & $0.277 \pm 0.008$ & $0.280 \pm 0.010$ & $0.245 \pm 0.011^{*}$ & $0.271 \pm 0.014$ & $0.223 \pm 0.016 \dagger$ \\
\hline Relative & $0.875 \pm 0.044$ & $0.857 \pm 0.014$ & $0.870 \pm 0.023$ & $0.887 \pm 0.033$ & $0.798 \pm 0.032$ & $0.904 \pm 0.049$ & $0.797 \pm 0.051$ \\
\hline \multicolumn{8}{|l|}{ Female } \\
\hline Necropsy body wt & $200 \pm 4$ & $197 \pm 2$ & $199 \pm 4$ & $194 \pm 5$ & $193 \pm 4$ & $182 \pm 4^{*}$ & $179 \pm 3 \dagger \dagger$ \\
\hline \multicolumn{8}{|l|}{ R. Kidney } \\
\hline Absolute & $0.72 \pm 0.01$ & $0.71 \pm 0.02$ & $0.73 \pm 0.02$ & $0.71 \pm 0.02$ & $0.74 \pm 0.02$ & $0.70 \pm 0.02$ & $0.75 \pm 0.01$ \\
\hline Relative & $3.59 \pm 0.07$ & $3.59 \pm 0.05$ & $3.65 \pm 0.04$ & $3.63 \pm 0.05$ & $3.85 \pm 0.06^{* *}$ & $3.86 \pm 0.07^{* *}$ & $4.17 \pm 0.09 \dagger \dagger$ \\
\hline \multicolumn{8}{|l|}{ Liver } \\
\hline Absolute & $6.97 \pm 0.18$ & $7.02 \pm 0.18$ & $6.93 \pm 0.23$ & $7.10 \pm 0.19$ & $7.14 \pm 0.18$ & $6.80 \pm 0.21$ & $7.58 \pm 0.13 \dagger$ \\
\hline Relative & $34.94 \pm 0.60$ & $35.62 \pm 0.79$ & $34.74 \pm 0.55$ & $36.60 \pm 0.62$ & $36.98 \pm 0.56$ & $37.28 \pm 0.56$ & $42.30 \pm 0.42 \dagger \dagger$ \\
\hline \multicolumn{8}{|l|}{ Thymus } \\
\hline Absolute & $0.279 \pm 0.016$ & $0.240 \pm 0.006 \dagger$ & $0.263 \pm 0.012$ & $0.245 \pm 0.013$ & $0.244 \pm 0.008$ & $0.225 \pm 0.009$ & $0.213 \pm 0.009 \dagger \dagger$ \\
\hline Relative & $1.395 \pm 0.071$ & $1.220 \pm 0.030 \dagger$ & $1.320 \pm 0.055$ & $1.265 \pm 0.064$ & $1.262 \pm 0.036$ & $1.236 \pm 0.046$ & $1.189 \pm 0.055 \dagger \dagger$ \\
\hline $\begin{array}{l}* \text { Significantly diffe } \\
* * \mathrm{P} \leq 0.01 \text {. } \\
+ \text { Significantly diffe } \\
\dagger † \mathrm{P} \leq 0.01 \text {. } \\
{ }^{\mathrm{a}} \text { Organ weights (ab } \\
\text { are given as mg org }\end{array}$ & $\begin{array}{l}\text { erent ( } P \leq 0.05) \\
\text { erent ( } P \leq 0.05) \\
\text { osolute weights) } \\
\text { gan weight/g bo }\end{array}$ & $\begin{array}{l}\text { from the vehic } \\
\text { from the untrea } \\
\text { and body weig } \\
\text { dy weight (mea }\end{array}$ & $\begin{array}{l}\text { le control group } \\
\text { ated control gro } \\
\text { ants are given in } \pm \text { standard es }\end{array}$ & $\begin{array}{l}\text { p by Williams' } \\
\text { oup by } t \text {-test. } \\
\text { n grams; organ- } \\
\text { rror). }\end{array}$ & -weight-to-body & J-weight ratios ( & relative weights) \\
\hline
\end{tabular}


and females (Table 4, Table A-1, Table A-2). The incidences of epidermal hyperplasia were significantly increased in $12.5 \%$ or greater males and all dosed groups of females. The incidences of epidermal hyperkeratosis and sebaceous gland hyperplasia were significantly increased in $25 \%$ or greater males and $12.5 \%$ or greater females. The incidences of epidermal ulcer were significantly increased in the $50 \%$ and $100 \%$ groups of males and females. The incidences of chronic active inflammation were significantly increased in $12.5 \%$ or greater males and females. The incidences of dermal fibrosis and hair follicle hyperplasia were significantly increased in $25 \%$ or greater males and females. Compared to normal skin (Figure 4 and Figure 5), epidermal hyperplasia was characterized by increased thickness of the epidermis due to an increase in the number of epithelial cell layers (Figure 6 and Figure 7). Hyperplasia frequently extended into and thickened the epithelium of the hair follicles and there were increased profiles of the hair follicle deep in the adjacent subcutaneous layers. Epithelial thicknesses of three, four, five, or greater than five layers of cells represented severity grades of minimal, mild, moderate, and marked, respectively. Epidermal hyperkeratosis generally accompanied hyperplasia and consisted of increased thickness of the epidermal keratin layer (Figure 8 and Figure 9). There were both ortho- and parakeratotic hyperkeratoses and the severities were determined by the number of increased cell layers compared to the respective controls. Frequently, there were dense accumulations of degenerate neutrophils within the keratin layers. Epidermal ulcer was characterized by focal, complete loss of the epidermis, often associated with necrosis of the underlying superficial dermis and filling of the epidermal defect with degenerate and/or necrotic cellular debris and degenerate inflammatory cells (Figure 10). The severity was based on the size of the ulcers and the number of affected areas in the skin section. Chronic active inflammation was characterized by infiltrates of neutrophils and macrophages in varying numbers (increasing with dose) throughout the dermis with infrequent extension into the hypodermis (Figure 11 and Figure 12). Occasionally, focal infiltrates of primarily neutrophils mixed with low numbers of macrophages were within the epidermis, hair follicles, and less frequently sebaceous glands. Dermal fibrosis was often associated with dermal inflammatory cell infiltrates and was characterized by increased amounts of collagenous/fibrous connective tissue in the dermis (Figure 13). Hair follicle hyperplasia was characterized by increased numbers of cross-sectional hair follicle profiles in association with thickening of the follicular epithelium that was an extension of the hyperplastic change that occurred in the epidermis (Figure 6 and Figure 7). Sebaceous gland hyperplasia was characterized by an increase in the size of the sebaceous glands due to increased number and size of the alveolar cells (Figure 6 and Figure 7).

Table 4. Incidences of Nonneoplastic Lesions of the Skin (Site of Application) in Rats in the Threemonth Dermal Study of Cedarwood Oil

\begin{tabular}{lccccccc}
\hline & $\begin{array}{c}\text { Untreated } \\
\text { Control }\end{array}$ & $\begin{array}{c}\text { Vehicle } \\
\text { Control }\end{array}$ & $\mathbf{6 . 2 5 \%}$ & $\mathbf{1 2 . 5 \%}$ & $\mathbf{2 5 \%}$ & $\mathbf{5 0 \%}$ & $\mathbf{1 0 0 \%}$ \\
\hline Male & & & & & & & \\
Number Examined Microscopically & 10 & 10 & 10 & 10 & 10 & 10 & 10 \\
Epidermis, Hyperplasia & 0 & 0 & $2(1.0)^{\mathrm{b}}$ & $4^{*}(1.3)$ & $10^{* *}(2.0)$ & $10^{* *}(2.9)$ & $9 \dagger \dagger(2.9)$ \\
Epidermis, Hyperkeratosis & 0 & 0 & 0 & $1(1.0)$ & $7^{* *}(1.1)$ & $10^{* *}(1.6)$ & $10 \dagger \dagger(3.0)$ \\
Sebaceous Gland, Hyperplasia & 0 & 0 & 0 & 0 & $9^{* *}(1.9)$ & $10^{* *}(2.8)$ & $10 \dagger \dagger(3.0)$ \\
\hline
\end{tabular}




\begin{tabular}{lccccccc}
\hline & $\begin{array}{c}\text { Untreated } \\
\text { Control }\end{array}$ & $\begin{array}{c}\text { Vehicle } \\
\text { Control }\end{array}$ & $\mathbf{6 . 2 5 \%}$ & $\mathbf{1 2 . 5 \%}$ & $\mathbf{2 5 \%}$ & $\mathbf{5 0 \%}$ & $\mathbf{1 0 0 \%}$ \\
\hline Epidermis, Ulcer & 0 & 0 & 0 & $1(1.0)$ & $1(3.0)$ & $7^{* *}(2.6)$ & $8 \dagger \dagger(3.0)$ \\
Inflammation, Chronic Active & 0 & 0 & $1(1.0)$ & $4^{*}(1.0)$ & $9^{* *}(1.4)$ & $10^{* *}(2.3)$ & $10 \dagger \dagger(2.7)$ \\
Dermis, Fibrosis & 0 & 0 & 0 & 0 & $7^{* *}(1.1)$ & $10^{* *}(2.4)$ & $10 \dagger \dagger(2.4)$ \\
Hair Follicle, Hyperplasia & 0 & 0 & 0 & 0 & $9^{* *}(1.3)$ & $10^{* *}(2.0)$ & $9 \dagger \dagger(1.8)$ \\
\hline Female & & & & & & & \\
Number Examined Microscopically & 10 & 10 & 10 & 10 & 10 & 10 & 10 \\
Epidermis, Hyperplasia & 0 & 0 & $4^{*}(1.0)$ & $7^{* *}(1.7)$ & $10^{* *}(2.1)$ & $10^{* *}(2.8)$ & $10 \dagger \dagger(3.0)$ \\
Epidermis, Hyperkeratosis & 0 & 0 & $1(1.0)$ & $5^{*}(1.0)$ & $10^{* *}(1.2)$ & $10^{* *}(2.5)$ & $10 \dagger \dagger(3.0)$ \\
Sebaceous Gland, Hyperplasia & 0 & 0 & 0 & $4^{*}(1.0)$ & $9^{* *}(1.8)$ & $10^{* *}(2.9)$ & $10 \dagger \dagger(3.0)$ \\
Epidermis, Ulcer & 0 & 0 & 0 & $1(2.0)$ & $1(3.0)$ & $4^{*}(2.3)$ & $10 \dagger \dagger(3.1)$ \\
Inflammation, Chronic Active & 0 & 0 & 0 & $7^{* *}(1.0)$ & $10^{* *}(1.2)$ & $10^{* *}(2.4)$ & $10 \dagger \dagger(2.4)$ \\
Dermis, Fibrosis & 0 & 0 & 0 & $1(1.0)$ & $7^{* *}(1.1)$ & $8^{* *}(1.8)$ & $10 \dagger \dagger(2.1)$ \\
Hair Follicle, Hyperplasia & 0 & 0 & 0 & $1(1.0)$ & $9^{* *}(1.7)$ & $10^{* *}(2.8)$ & $10 \dagger \dagger(3.6)$ \\
\hline
\end{tabular}

*Significantly different $(\mathrm{P} \leq 0.05)$ from the vehicle control group by the Fisher exact test.

$* * \mathrm{P} \leq 0.01$.

$\dagger †$ Significantly different $(\mathrm{P} \leq 0.01)$ from the untreated control group by the Fisher exact test.

${ }^{a}$ Number of animals with lesion.

${ }^{\mathrm{b}}$ Average severity grade of lesions in affected animals: $1=$ minimal, $2=$ mild, $3=$ moderate, $4=$ marked.

In the kidney, the incidences of renal tubule degeneration were significantly increased in $50 \%$ and $100 \%$ males compared to those in the respective control groups (Table 5 and Table A-1). In addition, the incidences of renal tubule granular casts and hyaline droplet accumulation were significantly increased in males in the $25 \%$ or greater groups compared to those in the respective control groups; the severity of these lesions increased with increasing dose. The severity of nephropathy in $50 \%$ and $100 \%$ males was mild compared to minimal in both control groups and the remaining dose groups. Renal tubule degeneration was a subtle lesion graded as minimal in all dose groups and was characterized by cell swelling, mild hypereosinophilia and sloughing of the tubule epithelial cells. Rare, sloughed degenerate epithelial cells were present in the lumen of the renal cortical tubules, of which the proximal convoluted tubules were primarily affected and the distal tubules were affected to a lesser extent. The sloughed cells were shrunken and had scant eosinophilic cytoplasm and condensed dark nuclei (Figure 14). Renal tubule granular casts consisted of variable dilation of the renal tubules along the corticomedullary junction with a lightly eosinophilic, granular material and occasionally mixed with cellular debris (Figure 15 and Figure 16). The severity of granular casts was graded as minimal if there were 10 or fewer casts in the transverse section of the kidney and 20 or fewer in the longitudinal section; mild if there were 11 to 20 casts in the transverse section and 21 to 49 in the longitudinal section; moderate if there were 21 to 49 casts in the transverse section and 50 or more in the longitudinal section; and marked when there were 50 or more casts each in the transverse and longitudinal sections. Hyaline droplet accumulation was characterized by variable amounts of granular to globular, intracytoplasmic eosinophilic, proteinaceous material within the epithelial cells of the proximal tubules. Severity of hyaline droplet accumulation was graded according to the character and amount of accumulated material in the tubule epithelial cells. In controls and males dosed with 
$6.25 \%$ or $12.5 \%$ cedarwood oil, the granules were fine and round (Figure 17 and Figure 18), whereas in males dosed with $50 \%$ or $100 \%$ cedarwood oil, the material appeared as larger, variable-sized round to irregular globules (Figure 19 and Figure 20). Nephropathy consisted of a few scattered renal tubule epithelial cell regeneration foci. The affected tubules had increased numbers of tubular epithelial cells that had basophilic cytoplasm compared to the eosinophilic cytoplasm of unaffected tubules. The basement membrane surrounding these tubules tended to be slightly thickened.

In the bone marrow, the incidences of hyperplasia were significantly increased in $100 \%$ males and females compared to those in the untreated control groups (Table 5, Table A-1, and Table A-2). Bone marrow hyperplasia was characterized by increased numbers of hematopoietic cells (primarily granulocytes) within the marrow cavity and was considered to be secondary to the lesions observed in the skin at the site of application.

Table 5. Incidences of Selected Nonneoplastic Lesions in Rats in the Three-month Dermal Study of Cedarwood Oil

\begin{tabular}{|c|c|c|c|c|c|c|c|}
\hline & $\begin{array}{l}\text { Untreated } \\
\text { Control }\end{array}$ & $\begin{array}{l}\text { Vehicle } \\
\text { Control }\end{array}$ & $6.25 \%$ & $12.5 \%$ & $25 \%$ & $50 \%$ & $100 \%$ \\
\hline \multicolumn{8}{|l|}{ Male } \\
\hline Kidney $^{\mathrm{a}}$ & 10 & 10 & 10 & 10 & 10 & 10 & 10 \\
\hline $\begin{array}{l}\text { Renal Tubule, } \\
\text { Degeneration }\end{array}$ & $2(1.0)^{\mathrm{c}}$ & $4(1.0)$ & $5(1.0)$ & $6(1.0)$ & $7(1.0)$ & $10^{* *}(1.0)$ & $10 \dagger \dagger(1.0)$ \\
\hline $\begin{array}{l}\text { Renal Tubule, } \\
\text { Casts Granular }\end{array}$ & 0 & 0 & 0 & 0 & $5^{*}(1.0)$ & $10^{* *}(1.6)$ & $10 \dagger \dagger(3.5)$ \\
\hline $\begin{array}{l}\text { Accumulation, } \\
\text { Hyaline Droplet }\end{array}$ & 0 & 0 & 0 & 0 & $10^{* *}(1.1)$ & $10 * *(1.9)$ & $10 \dagger \dagger(3.0)$ \\
\hline Nephropathy & $10(1.0)$ & $10(1.0)$ & $10(1.0)$ & $10(1.0)$ & $10(1.0)$ & $10(2.0)$ & $10(2.0)$ \\
\hline Bone Marrow & 10 & 10 & 10 & 10 & 10 & 10 & 10 \\
\hline Hyperplasia & 0 & 0 & 0 & 0 & 0 & $1(1.0)$ & $7 \dagger †$ (1.1) \\
\hline \multicolumn{8}{|l|}{ Female } \\
\hline Bone Marrow & 10 & 10 & 9 & 10 & 10 & 10 & 10 \\
\hline Hyperplasia & 0 & 0 & 0 & 0 & $2(1.0)$ & $2(1.0)$ & $7 \dagger \dagger(1.0)$ \\
\hline
\end{tabular}

\section{Three-month Study in Mice}

Due to the severities of lesions in the skin at the site of application, all males and females in the $100 \%$ groups, one male and one female each in the $50 \%$ groups, and one male in the $12.5 \%$ group were euthanized during weeks 10,11 , and 12, respectively; all other male and female mice survived to the end of the study (Table 6). The final mean body weights of $25 \%$ and $50 \%$ males and $12.5 \%$ or greater females and the mean body weight gains of $12.5 \%$ or greater males and females were significantly less than those of the vehicle control groups (Table 6 and Figure 3). 
Test article-related clinical observations included irritation, thickening, and ulceration of the skin at the site of application in most of the dosed mice.

The hematology data for mice are presented in Table B-2. Similar to the rat study, increases in total and differential white blood cell counts occurred. The leukon changes were characterized primarily by small (20\% to 30\%) increases in the total white blood cell counts of $25 \%$ and $50 \%$ females and two- to threefold increases in neutrophil counts in $25 \%$ female and $50 \%$ male and female groups. Also similar to the rat study was the presence of a decreased erythron. In the mice, however, the evidence was more consistent and widespread involving decreases of all three estimators of the circulating red cell mass (i.e., the hematocrit values, hemoglobin concentrations, and erythrocyte counts) in $12.5 \%$ males and $25 \%$ and $50 \%$ males and females. In addition, the severity of the erythron decrease (approximately 13\%) in the 50\% groups was more than twice that of the 100\% groups (approximately 5\%).

There were no changes in the number of sperm and spermatids, sperm motility, or testis and epididymis weights of dosed males (Table D-4). There were no estrous cycle changes in dosed females (Table D-5 and Table D-6; Figure D-2). Under the conditions of this study, cedarwood oil applied dermally did not exhibit the potential to be a reproductive toxicant in male or female B6C3F1/N mice.

Table 6. Survival and Body Weights of Mice in the Three-month Dermal Study of Cedarwood Oil ${ }^{\mathrm{a}}$

\begin{tabular}{|c|c|c|c|c|c|}
\hline $\begin{array}{c}\text { Concentration } \\
(\%)\end{array}$ & Survival $^{\mathbf{b}}$ & $\begin{array}{l}\text { Initial Body } \\
\text { Weight } \\
\text { (g) }\end{array}$ & $\begin{array}{c}\text { Final Body } \\
\text { Weight } \\
\text { (g) }\end{array}$ & $\begin{array}{c}\text { Change in Body } \\
\text { Weight } \\
\text { (g) }\end{array}$ & $\begin{array}{c}\text { Final Weight } \\
\text { Relative } \\
\text { to Controls } \\
(\%)\end{array}$ \\
\hline \multicolumn{6}{|l|}{ Male } \\
\hline Untreated Control & $10 / 10$ & $21.9 \pm 0.4$ & $39.7 \pm 1.3$ & $17.8 \pm 1.1$ & \\
\hline Vehicle Control & $10 / 10$ & $21.7 \pm 0.3$ & $36.9 \pm 0.8$ & $15.2 \pm 0.6$ & \\
\hline 6.25 & $10 / 10$ & $21.7 \pm 0.3$ & $36.0 \pm 0.6$ & $14.4 \pm 0.5$ & 98 \\
\hline 12.5 & $9 / 10^{c}$ & $22.1 \pm 0.4$ & $35.1 \pm 1.1$ & $13.1 \pm 0.9 *$ & 95 \\
\hline 25 & $10 / 10$ & $22.1 \pm 0.5$ & $33.1 \pm 0.9^{* *}$ & $11.0 \pm 0.7^{* *}$ & 90 \\
\hline 50 & $9 / 10^{d}$ & $22.1 \pm 0.4$ & $31.9 \pm 0.7^{* *}$ & $9.7 \pm 0.6^{* *}$ & 86 \\
\hline 100 & $0 / 10^{\mathrm{e}}$ & - & - & - & - \\
\hline \multicolumn{6}{|l|}{ Female } \\
\hline Untreated Control & $10 / 10$ & $18.1 \pm 0.2$ & $34.9 \pm 0.9$ & $16.8 \pm 0.9$ & \\
\hline Vehicle Control & $10 / 10$ & $17.8 \pm 0.3$ & $34.7 \pm 1.1$ & $16.9 \pm 1.0$ & \\
\hline 6.25 & $10 / 10$ & $18.0 \pm 0.4$ & $34.0 \pm 0.9$ & $16.1 \pm 0.7$ & 98 \\
\hline 12.5 & $10 / 10$ & $17.9 \pm 0.2$ & $30.5 \pm 0.7^{* *}$ & $12.6 \pm 0.7^{* *}$ & 88 \\
\hline 25 & $10 / 10$ & $17.8 \pm 0.5$ & $28.1 \pm 0.6^{* *}$ & $10.3 \pm 0.6^{* *}$ & 81 \\
\hline 50 & $9 / 10^{\mathrm{d}}$ & $18.3 \pm 0.4$ & $30.2 \pm 0.4^{* *}$ & $11.9 \pm 0.5^{* *}$ & 87 \\
\hline 100 & $0 / 10^{\mathrm{e}}$ & - & - & - & - \\
\hline
\end{tabular}

*Significantly different $(\mathrm{P} \leq 0.05)$ from the vehicle control group by Williams' test.

$* * \mathrm{P} \leq 0.01$.

${ }^{a}$ Weights and weight changes are given as mean \pm standard error.

${ }^{b}$ Number of animals surviving at 14 weeks/number initially in group.

'Week of death: 12.

${ }^{\mathrm{d}}$ Week of death: 11 .

eDue to the severity of skin lesions, all 100\% mice were euthanized during week 10 . 

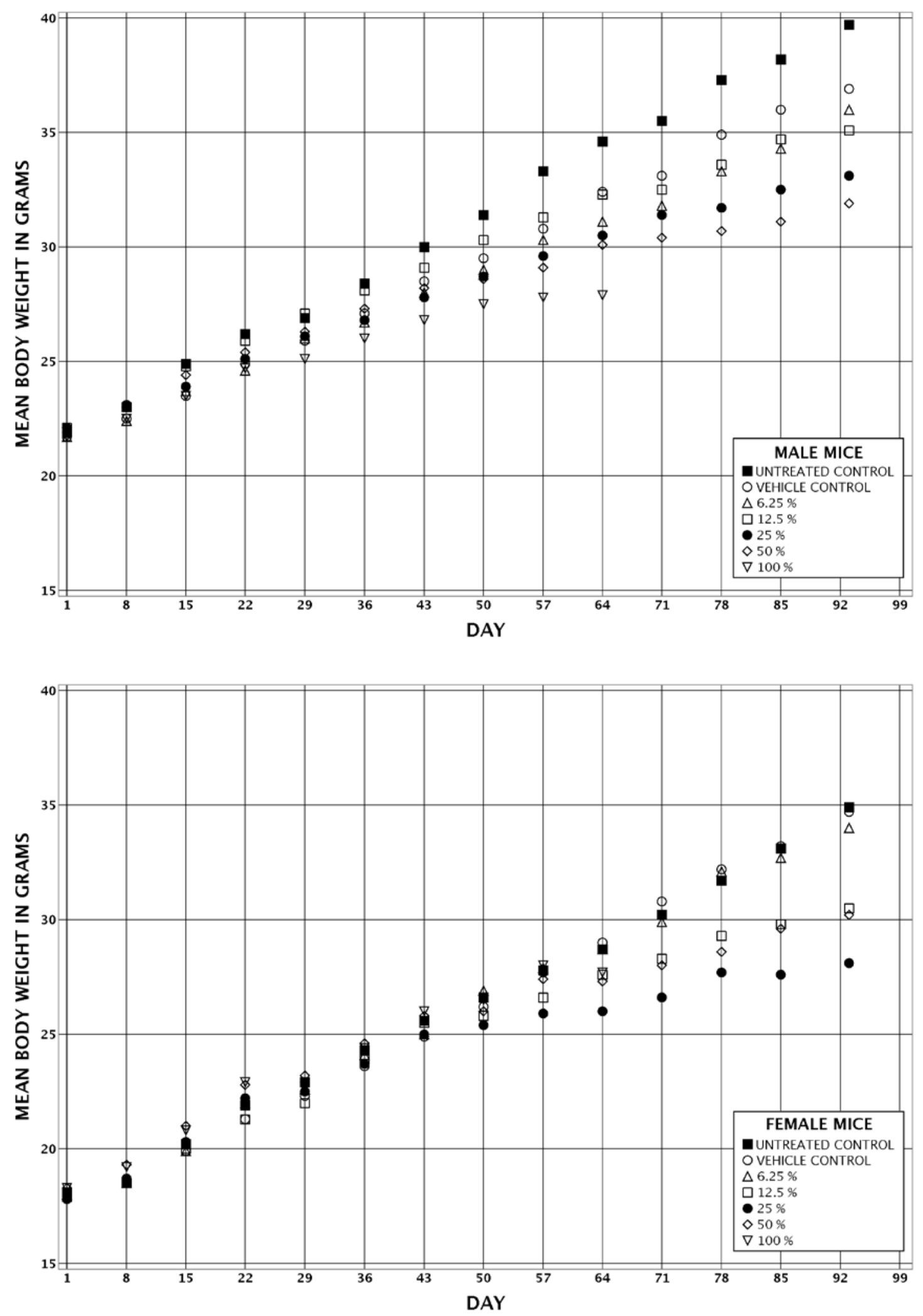

Figure 3. Growth Curves for Mice Administered Cedarwood Oil Dermally for Three Months 
Absolute liver weights of 50\% males and females and relative liver weights of all dosed groups of males and females were significantly greater than those of the vehicle control groups (Table 7 and Table C-2). The absolute kidney weight of 50\% females and relative kidney weights of 50\% males and $12.5 \%$ or greater females were significantly greater than those of the vehicle control groups. However, the kidney weight changes in males are most likely attributable to overall body weight changes. Absolute thymus weights of $25 \%$ and $50 \%$ males and $12.5 \%$ or greater females were significantly less than those of the vehicle controls.

Table 7. Organ Weights and Organ-Weight-to-Body-Weight Ratios for Mice in the Three-month Dermal Study of Cedarwood Oil ${ }^{\text {a,b }}$

\begin{tabular}{|c|c|c|c|c|c|}
\hline & $\begin{array}{l}\text { Vehicle } \\
\text { Control }\end{array}$ & $6.25 \%$ & $12.5 \%$ & $25 \%$ & $50 \%$ \\
\hline $\mathbf{n}$ & 10 & 10 & 9 & 10 & 9 \\
\hline \multicolumn{6}{|l|}{ Male } \\
\hline Necropsy body wt & $36.9 \pm 0.8$ & $36.0 \pm 0.6$ & $35.1 \pm 1.1$ & $33.1 \pm 0.9 * *$ & $31.9 \pm 0.7^{* *}$ \\
\hline \multicolumn{6}{|l|}{ R. Kidney } \\
\hline Absolute & $0.29 \pm 0.01$ & $0.29 \pm 0.01$ & $0.30 \pm 0.01$ & $0.28 \pm 0.01$ & $0.29 \pm 0.01$ \\
\hline Relative & $7.94 \pm 0.12$ & $8.16 \pm 0.22$ & $8.51 \pm 0.21$ & $8.35 \pm 0.26$ & $9.03 \pm 0.14^{* *}$ \\
\hline \multicolumn{6}{|l|}{ Liver } \\
\hline Absolute & $1.66 \pm 0.04$ & $1.76 \pm 0.04$ & $1.81 \pm 0.05$ & $1.77 \pm 0.06$ & $1.98 \pm 0.04 * *$ \\
\hline Relative & $45.06 \pm 0.58$ & $48.85 \pm 1.18^{* *}$ & $51.51 \pm 0.57 * *$ & $53.44 \pm 1.06^{* *}$ & $62.12 \pm 1.21^{* *}$ \\
\hline \multicolumn{6}{|l|}{ Thymus } \\
\hline Absolute & $0.048 \pm 0.004$ & $0.050 \pm 0.002$ & $0.044 \pm 0.003$ & $0.040 \pm 0.001 *$ & $0.038 \pm 0.002 *$ \\
\hline Relative & $1.306 \pm 0.077$ & $1.374 \pm 0.057$ & $1.232 \pm 0.063$ & $1.224 \pm 0.041$ & $1.205 \pm 0.073$ \\
\hline \multicolumn{6}{|l|}{ Female } \\
\hline Necropsy body wt & $34.7 \pm 1.1$ & $34.0 \pm 0.9$ & $30.5 \pm 0.7^{* *}$ & $28.1 \pm 0.6^{* *}$ & $30.2 \pm 0.4^{* *}$ \\
\hline \multicolumn{6}{|l|}{ R. Kidney } \\
\hline Absolute & $0.19 \pm 0.01$ & $0.20 \pm 0.00$ & $0.20 \pm 0.00$ & $0.20 \pm 0.00$ & $0.24 \pm 0.01^{* *}$ \\
\hline Relative & $5.58 \pm 0.18$ & $5.94 \pm 0.13$ & $6.67 \pm 0.18^{* *}$ & $7.07 \pm 0.15^{* *}$ & $7.86 \pm 0.16^{* *}$ \\
\hline \multicolumn{6}{|l|}{ Liver } \\
\hline Absolute & $1.58 \pm 0.05$ & $1.65 \pm 0.02$ & $1.62 \pm 0.03$ & $1.60 \pm 0.04$ & $2.05 \pm 0.05^{* *}$ \\
\hline Relative & $45.61 \pm 0.79$ & $48.75 \pm 0.79 *$ & $53.24 \pm 0.77^{* *}$ & $57.10 \pm 1.02^{* *}$ & $67.80 \pm 0.82^{* *}$ \\
\hline \multicolumn{6}{|l|}{ Thymus } \\
\hline Absolute & $0.061 \pm 0.004$ & $0.068 \pm 0.004$ & $0.051 \pm 0.002 *$ & $0.051 \pm 0.003 *$ & $0.045 \pm 0.002^{* *}$ \\
\hline Relative & $1.759 \pm 0.087$ & $1.990 \pm 0.096$ & $1.679 \pm 0.063$ & $1.802 \pm 0.076$ & $1.506 \pm 0.070$ \\
\hline
\end{tabular}

*Significantly different $(\mathrm{P} \leq 0.05)$ from the vehicle control group by Williams' or Dunnett’s test.

$* * \mathrm{P} \leq 0.01$.

${ }^{a}$ Organ weights (absolute weights) and body weights are given in grams; organ-weight-to-body-weight ratios (relative weights) are given as mg organ weight/g body weight (mean \pm standard error).

${ }^{b}$ Due to the severity of skin lesions, all 100\% mice were euthanized during week 10 . 
The incidences of epidermal hyperplasia, hyperkeratosis, and ulcer and chronic active inflammation, dermal fibrosis, hair follicle hyperplasia, and sebaceous gland hyperplasia were significantly increased in most groups of males and females (Table 8, Table A-3, and Table A-4).

Table 8. Incidences of Nonneoplastic Lesions of the Skin (Site of Application) in Mice in the Threemonth Dermal Study of Cedarwood Oil

\begin{tabular}{|c|c|c|c|c|c|c|c|}
\hline & $\begin{array}{c}\text { Untreated } \\
\text { Control }\end{array}$ & $\begin{array}{l}\text { Vehicle } \\
\text { Control }\end{array}$ & $6.25 \%$ & $12.5 \%$ & $25 \%$ & $50 \%$ & $100 \%^{\mathrm{a}}$ \\
\hline \multicolumn{8}{|l|}{ Male } \\
\hline Number Examined Microscopically & 10 & 9 & 10 & 10 & 10 & 10 & 10 \\
\hline Epidermis, Hyperplasiab & 0 & 0 & $10^{* *}(2.6)^{\mathrm{c}}$ & $10 * *(3.0)$ & $10 * *(3.0)$ & $10 * *(3.0)$ & $10 \dagger \dagger(3.0)$ \\
\hline Epidermis, Hyperkeratosis & 0 & 0 & $7 * *(2.1)$ & $10 * *(2.9)$ & $10 * *(3.0)$ & $10^{* *}(2.9)$ & $10 \dagger \dagger(2.9)$ \\
\hline Epidermis, Ulcer & 0 & 0 & $2(4.0)$ & $8^{* *}(4.0)$ & $10^{* *}(3.8)$ & $9 * *(3.7)$ & $10 \dagger \dagger(3.9)$ \\
\hline Inflammation, Chronic Active & 0 & 0 & $10^{* *}(2.4)$ & $10 * *(3.0)$ & $10 * *(3.0)$ & $10 * *(3.0)$ & $10 \dagger \dagger(3.2)$ \\
\hline Dermis, Fibrosis & 0 & 0 & $3(2.7)$ & $10 * *(3.0)$ & $10 * *(3.0)$ & $10 * *(3.0)$ & $10 \dagger \dagger(3.0)$ \\
\hline Hair Follicle, Hyperplasia & 0 & 0 & $10 * *(2.6)$ & $10 * *(3.0)$ & $10 * *(3.0)$ & $10 * *(3.0)$ & $10 \dagger \dagger(3.0)$ \\
\hline Sebaceous Gland, Hyperplasia & 0 & 0 & $10^{* *}(1.3)$ & $10 * *(2.3)$ & $10 * *(2.6)$ & $10 * *(2.3)$ & $10 \dagger \dagger(2.0)$ \\
\hline \multicolumn{8}{|l|}{ Female } \\
\hline Number Examined Microscopically & 10 & 10 & 10 & 10 & 10 & 10 & 10 \\
\hline Epidermis, Hyperplasia & 0 & 0 & $10 * *(2.1)$ & $10 * *(3.0)$ & $10 * *(3.0)$ & $10 * *(3.0)$ & $10 \dagger \dagger(3.0)$ \\
\hline Epidermis, Hyperkeratosis & 0 & 0 & $2(1.5)$ & $10^{* *}(2.7)$ & $10^{* *}(3.0)$ & $10^{* *}(3.0)$ & $10 \dagger \dagger(3.0)$ \\
\hline Epidermis, Ulcer & 0 & 0 & $2(3.0)$ & $6^{* *}(3.7)$ & $9 * *(4.0)$ & $10 * *(4.0)$ & $10 \dagger \dagger(4.0)$ \\
\hline Inflammation, Chronic Active & 0 & 0 & $10 * *(2.2)$ & $10 * *(3.0)$ & $10 * *(3.0)$ & $10 * *(3.0)$ & $10 \dagger \dagger(3.0)$ \\
\hline Dermis, Fibrosis & 0 & 0 & $2(1.0)$ & $10 * *(2.9)$ & $10 * *(3.0)$ & $10 * *(3.0)$ & $10 \dagger \dagger(3.0)$ \\
\hline Hair Follicle, Hyperplasia & 0 & 0 & $3(2.3)$ & $10 * *(3.0)$ & $10 * *(3.0)$ & $10 * *(3.0)$ & $10 \dagger \dagger(3.0)$ \\
\hline Sebaceous Gland, Hyperplasia & $1(1.0)$ & 0 & $4 *(1.3)$ & $10^{* *}(2.0)$ & $10 * *(2.2)$ & $10 * *(2.0)$ & $10 \dagger \dagger(2.2)$ \\
\hline
\end{tabular}

In general, the site of application lesions that occurred in mice were morphologically similar to those observed in the rat study. Hair follicle hyperplasia was characterized by increased numbers of cross-sectional hair follicle profiles in association with thickening of the follicular epithelium that was an extension of the hyperplastic change that occurred in the epidermis. The associated sebaceous glands were variably enlarged due to increases in size and numbers of alveolar cells (sebaceous gland hyperplasia).

In the liver, the incidences of hepatocyte glycogen depletion were significantly increased in males and females in the $12.5 \%$ or greater groups compared to those in the respective control groups (Table 9, Table A-3, and Table A-4). The large, coalescing, perinuclear clear spaces (consistent with glycogen accumulation) present in the cytoplasm of hepatocytes of the controls were absent from the cytoplasm of the hepatocytes of dosed mice having the lesion. The 
cytoplasm of hepatocytes in the dosed mice appeared homogeneously eosinophilic or granular and contained basophilic floccular material. This was especially prominent in the $100 \%$ groups. With decreasing dose, the cytoplasm of hepatocytes appeared similar to that of the $100 \%$ groups although the clear cytoplasmic spaces were increasingly apparent but not as prominent or frequent as those in the control groups.

Compared to incidences in the respective control groups, the incidences of bone marrow myeloid cell hyperplasia were significantly increased in all dosed groups of males and females (except $6.25 \%$ females) and the incidences of hematopoietic cell proliferation in the spleen were significantly increased in all dosed groups of mice (Table 9, Table A-3, and Table A-4). With the exceptions of $6.25 \%$ males and $25 \%$ females, the incidences of lymphoid hyperplasia were significantly increased in the mandibular lymph node of all dosed groups. Lymphoid hyperplasia occurred in the axillary lymph nodes of all mice, except one male in the $100 \%$ groups; one female in the $50 \%$ group also had axillary lymph node hyperplasia. Occurrences of these lesions were considered secondary to the lesions observed in the skin at the site of application. Bone marrow myeloid cell hyperplasia was characterized by increased numbers of hematopoietic cells (primarily granulocytes) within the marrow cavity of dosed animals. Splenic hematopoietic cell proliferation was characterized by expansion of the red pulp by myeloid and erythroid precursors and varying numbers of megakaryocytes. Lymphoid hyperplasia in the lymph nodes was characterized by increased numbers of lymphocytes in the lymphoid follicles and follicular and paracortical zones.

In the thymus, the incidences of atrophy were significantly increased in $25 \%$ or greater males compared to those in the respective controls (Table 9 and Table A-3). Atrophy consisted of depletion of thymocytes in the cortex of the thymus.

In the kidney, the incidence of nephropathy was significantly increased in 100\% males compared to that in the untreated controls (Table 9 and Table A-3). Nephropathy consisted of sparsely scattered, focal areas of renal tubules lined by increased numbers of epithelial cells that had basophilic cytoplasm compared to surrounding normal tubules that were lined by epithelial cells that had eosinophilic cytoplasm.

Table 9. Incidences of Selected Nonneoplastic Lesions in Mice in the Three-month Dermal Study of Cedarwood Oil

\begin{tabular}{|c|c|c|c|c|c|c|c|}
\hline & $\begin{array}{l}\text { Untreated } \\
\text { Control }\end{array}$ & $\begin{array}{l}\text { Vehicle } \\
\text { Control }\end{array}$ & $6.25 \%$ & $12.5 \%$ & $25 \%$ & $50 \%$ & $100 \%^{\mathrm{a}}$ \\
\hline \multicolumn{8}{|l|}{ Male } \\
\hline Liver $^{\mathrm{b}}$ & 10 & 10 & 10 & 10 & 10 & 10 & 10 \\
\hline $\begin{array}{l}\text { Hepatocyte, } \\
\text { Depletion Glycogen }\end{array}$ & 0 & 0 & 0 & $6^{* *}(1.8)^{\mathrm{d}}$ & $9 * *(2.2)$ & $10^{* *}(3.0)$ & $10 \dagger \dagger(3.0)$ \\
\hline Bone Marrow & 10 & 10 & 10 & 10 & 10 & 10 & 10 \\
\hline Myeloid Cell, Hyperplasia & 0 & 0 & $5 *(1.0)$ & $10 * *(1.6)$ & $10 * *(2.1)$ & $10 * *(2.8)$ & $10 \dagger \dagger(4.0)$ \\
\hline Spleen & 10 & 10 & 10 & 10 & 10 & 10 & 10 \\
\hline $\begin{array}{l}\text { Hematopoietic Cell } \\
\text { Proliferation }\end{array}$ & 0 & 0 & $6 * *(2.0)$ & $10 * *(2.3)$ & $10 * *(2.5)$ & $10 * *(3.0)$ & $10 \dagger \dagger(2.9)$ \\
\hline Lymph Node, Mandibular & 10 & 10 & 10 & 10 & 9 & 10 & 10 \\
\hline Hyperplasia, Lymphoid & 0 & 0 & $1(3.0)$ & $6^{* *}(3.0)$ & $5 *(2.6)$ & $9 * *(3.2)$ & $8 \dagger \dagger(3.4)$ \\
\hline
\end{tabular}




\begin{tabular}{|c|c|c|c|c|c|c|c|}
\hline & $\begin{array}{l}\text { Untreated } \\
\text { Control }\end{array}$ & $\begin{array}{l}\text { Vehicle } \\
\text { Control }\end{array}$ & $6.25 \%$ & $12.5 \%$ & $25 \%$ & $50 \%$ & $100 \%^{a}$ \\
\hline Lymph Node & $\mathrm{e}^{\mathrm{e}}$ & - & - & - & - & - & 9 \\
\hline $\begin{array}{l}\text { Axillary, Hyperplasia, } \\
\text { Lymphoid }\end{array}$ & - & - & - & - & - & - & $9(3.9)$ \\
\hline Thymus & 10 & 10 & 10 & 10 & 10 & 10 & 10 \\
\hline Atrophy & 0 & 0 & 0 & 0 & $5^{*}(1.8)$ & $10^{* *}(1.7)$ & $10 \dagger \dagger(1.8)$ \\
\hline Kidney & 10 & 10 & 10 & 10 & 10 & 10 & 10 \\
\hline Nephropathy & 0 & $2(1.0)$ & 0 & $1(1.0)$ & $2(1.0)$ & $3(1.3)$ & $5 \dagger(1.0)$ \\
\hline \multicolumn{8}{|l|}{ Female } \\
\hline Liver & 10 & 10 & 10 & 10 & 10 & 10 & 10 \\
\hline $\begin{array}{l}\text { Hepatocyte, } \\
\text { Depletion Glycogen }\end{array}$ & 0 & 0 & 0 & $5 *(1.4)$ & $9 * *(2.1)$ & $10 * *(2.5)$ & $10 \dagger \dagger(3.5)$ \\
\hline Bone Marrow & 10 & 10 & 10 & 10 & 10 & 10 & 10 \\
\hline Myeloid Cell, Hyperplasia & 0 & 0 & $2(1.5)$ & $9 * *(1.4)$ & $10 * *(3.0)$ & $10 * *(3.0)$ & $10 \dagger \dagger(4.0)$ \\
\hline Spleen & 10 & 10 & 10 & 10 & 10 & 10 & 10 \\
\hline $\begin{array}{l}\text { Hematopoietic } \\
\text { Cell Proliferation }\end{array}$ & $4(2.0)$ & $2(2.0)$ & $9 * *(2.1)$ & $10 * *(2.7)$ & $10 * *(2.6)$ & $10 * *(3.0)$ & $10 \dagger \dagger(3.0)$ \\
\hline Lymph Node, Mandibular & 10 & 10 & 10 & 10 & 10 & 10 & 10 \\
\hline Hyperplasia, Lymphoid & 0 & $1(3.0)$ & $6^{*}(2.7)$ & $6 *(3.0)$ & $5(3.6)$ & $6^{*}(3.5)$ & $10 \dagger \dagger(3.4)$ \\
\hline Lymph Node & - & - & - & - & 1 & 2 & 10 \\
\hline $\begin{array}{l}\text { Axillary, Hyperplasia, } \\
\text { Lymphoid }\end{array}$ & - & - & - & - & 0 & $1(4.0)$ & $10(3.6)$ \\
\hline
\end{tabular}

*Significantly different $(\mathrm{P} \leq 0.05)$ from the vehicle control group by the Fisher exact test.

$* * \mathrm{P} \leq 0.01$.

$\dagger$ Significantly different $(\mathrm{P} \leq 0.05)$ from the untreated control group by the Fisher exact test.

$\dagger+\mathrm{P} \leq 0.01$.

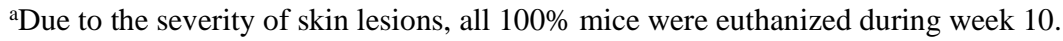

bNumber of animals with tissue examined microscopically.

${ }^{\mathrm{c}}$ Number of animals with lesion.

${ }^{\mathrm{d} A v e r a g e ~ s e v e r i t y ~ g r a d e ~ o f ~ l e s i o n s ~ i n ~ a f f e c t e d ~ a n i m a l s: ~} 1=$ minimal, $2=$ mild, $3=$ moderate, $4=$ marked.

eTissue was not assessed in this group; the axillary lymph node is not a protocol required tissue and is collected and evaluated microscopically only when grossly abnormal.

\section{Genetic Toxicology}

Cedarwood oil (0.33 to $333 \mu \mathrm{g} /$ plate) was not mutagenic in Salmonella typhimurium strains TA98, TA100, or TA102 when tested with or without 10\% induced rat liver S9 metabolic activation enzymes (Table E-1). In vivo, no significant increases in micronucleated erythrocytes (normochromatic erythrocytes; NCEs) were observed in blood samples from male B6C3F1/N mice following 3 months of dermal exposure to cedarwood oil (6.25\% to 50\%) (Table E-2). In female B6C3F1/N mice treated with cedarwood oil for 3 months, small increases in the frequencies of micronucleated erythrocytes were seen at the two highest doses (25\% and 50\%), but the mean value for micronucleated erythrocytes in each of these two treatment groups was not significantly elevated over the mean value in the vehicle control group. Because the trend test was significant $(\mathrm{P}=0.011)$, the results of the micronucleus assay in female mice were judged to be equivocal. No significant alterations in the percentage of micronucleated reticulocytes 


\section{Cedarwood Oil, NTP TOX 86}

(polychromatic erythrocytes; PCEs) were seen in male or female mice, suggesting that cedarwood oil applied dermally did not induce bone marrow toxicity.

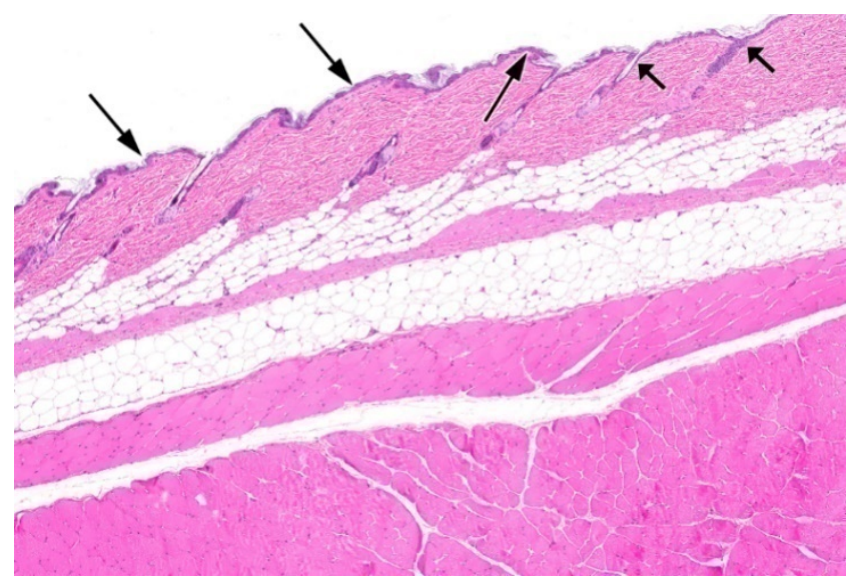

Figure 4. Normal Skin (Site of Application) of a Vehicle Control Female F344/N Rat in the Threemonth Dermal Study of Cedarwood Oil (H\&E)

The epidermis (long arrows) is composed of a single layer of epithelial cells, and hair follicles are few and evenly spaced (short arrows).

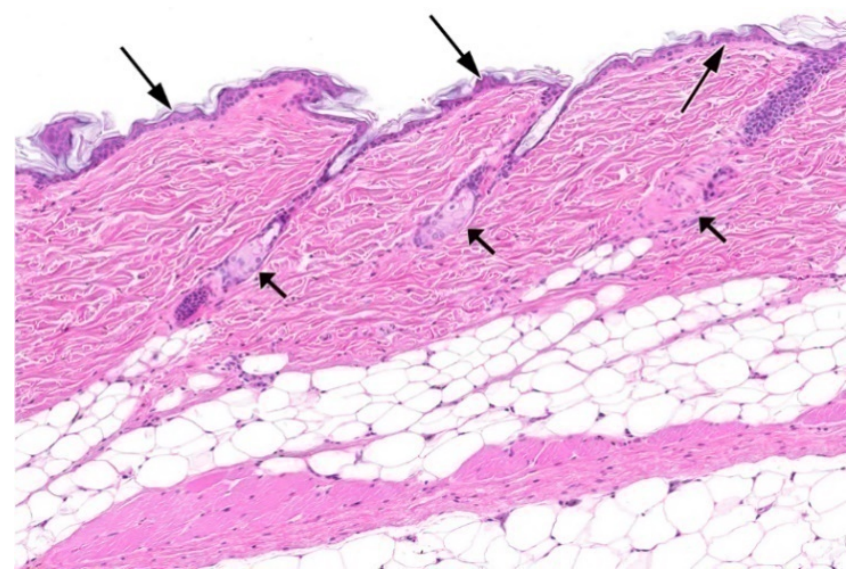

Figure 5. Higher Magnification of Figure 4 (H\&E)

Note the epidermis (long arrows) and hair follicles with associated sebaceous glands (short arrows). 


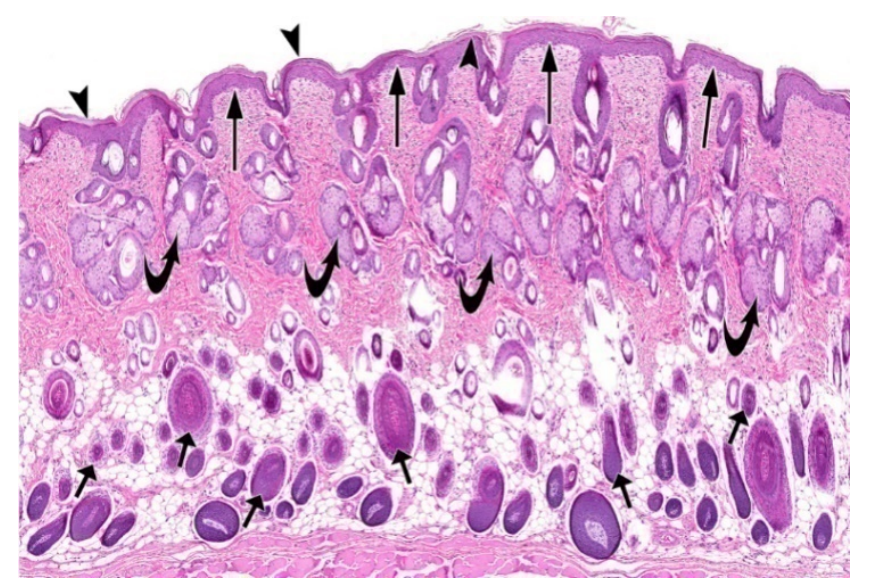

Figure 6. Hyperplasia and Hyperkeratosis of the Epidermis (Site of Application) in the Skin of a Female F344/N Rat Administered 100\% Cedarwood Oil Dermally for Three Months (H\&E)

Compared to Figure 4, the epidermis (long arrows) and overlying keratin layer (arrowheads) are prominently thickened. Note that there are increased numbers of hair follicle profiles (hair follicle hyperplasia) within the dermis and subcutis (short arrows), and that the number and size of the associated sebaceous glands (curved arrows) are increased (sebaceous gland hyperplasia). 


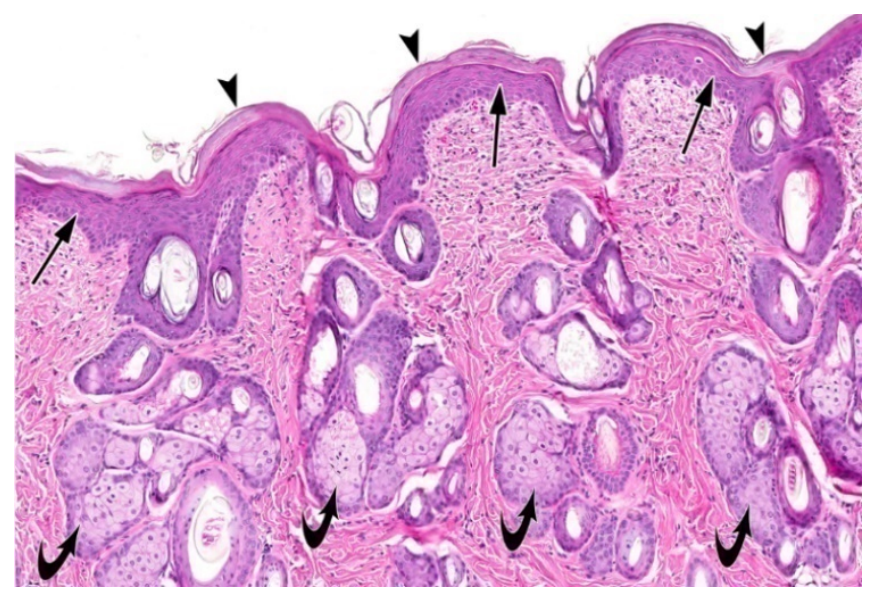

Figure 7. Higher Magnification of Figure 6 (H\&E)

Note the thickened (hyperplastic) epidermis (long arrows), hyperkeratosis (arrowheads), and sebaceous gland hyperplasia (curved arrows).

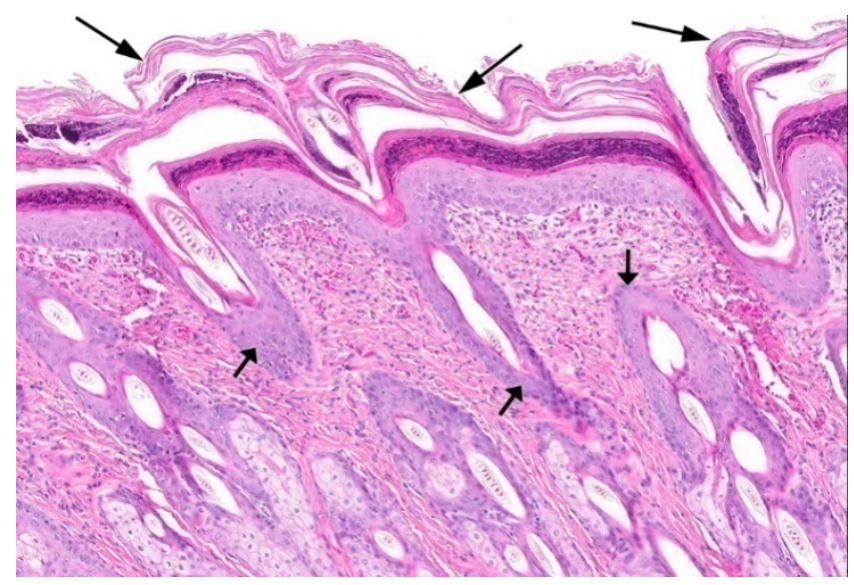

Figure 8. Epidermal Hyperkeratosis in the Skin (Site of Application) of a Female F344/N Rat Administered $100 \%$ Cedarwood Oil Dermally for Three Months (H\&E)

There is prominent thickening of the keratin layer (long arrows) that contains accumulations of degenerate neutrophils. Note that as an extension of epidermal hyperplasia, the epithelium of the hair follicles is also hyperplastic (short arrows). Note also the infiltrates of inflammatory cells in the dermis. 


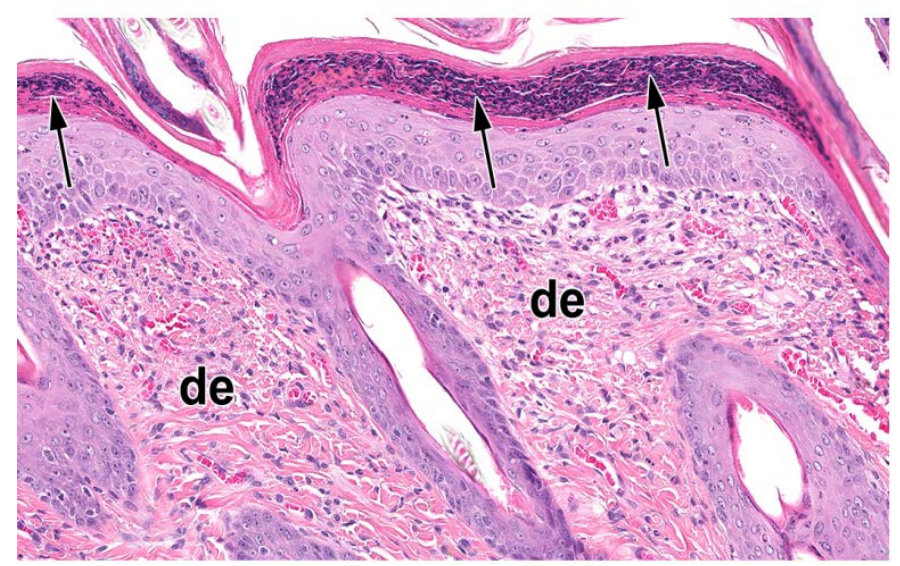

Figure 9. Higher Magnification of Figure 8 (H\&E)

Note dense accumulations of degenerate neutrophils within the hyperplastic keratin layer (arrows) and infiltrates of inflammatory cells within the dermis (de).

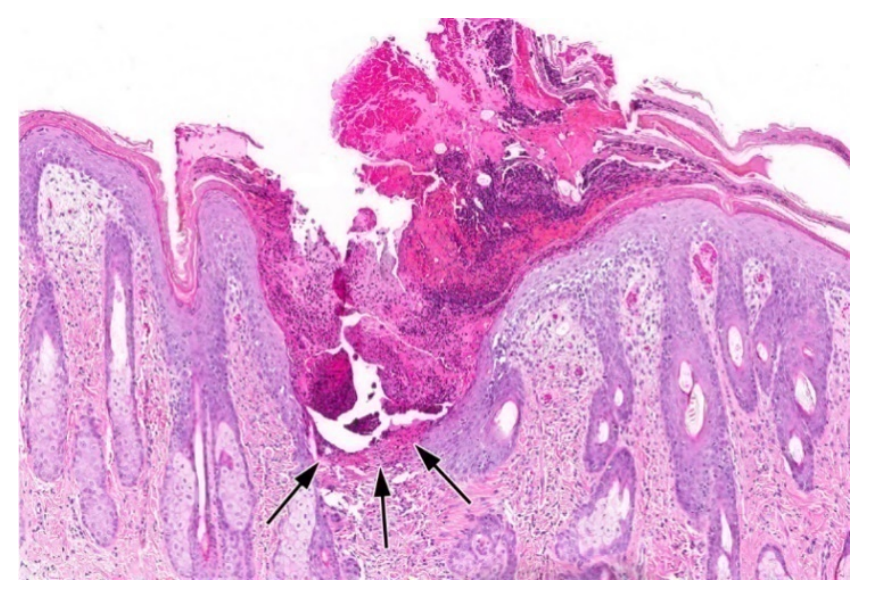

Figure 10. Focal Epidermal Ulcer in the Skin (Site of Application) of a Female F344/N Rat Administered $\mathbf{1 0 0 \%}$ Cedarwood Oil Dermally for Three Months (H\&E)

Note focal complete loss of the epidermis (arrows) with accumulation of serum protein mixed with necrotic cellular debris at the site of ulceration. Note also epidermal, hair follicle, and sebaceous gland hyperplasia. 


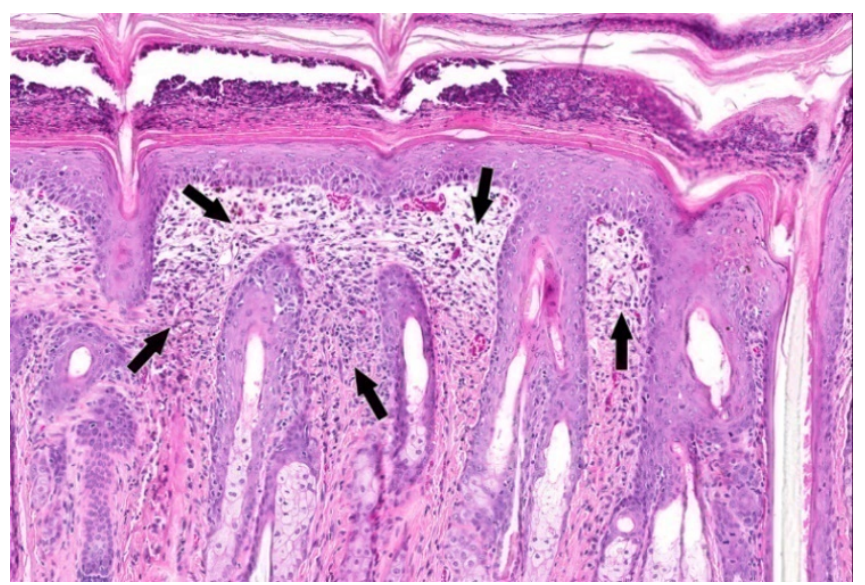

Figure 11. Marked Chronic Active Inflammation in the Skin (Site of Application) of a Female F344/N Rat Administered 100\% Cedarwood Oil Dermally for Three Months (H\&E)

Note a mixed inflammatory cell infiltrate within the dermis (arrows) and dense accumulation of degenerate neutrophils within the thickened keratin layer.

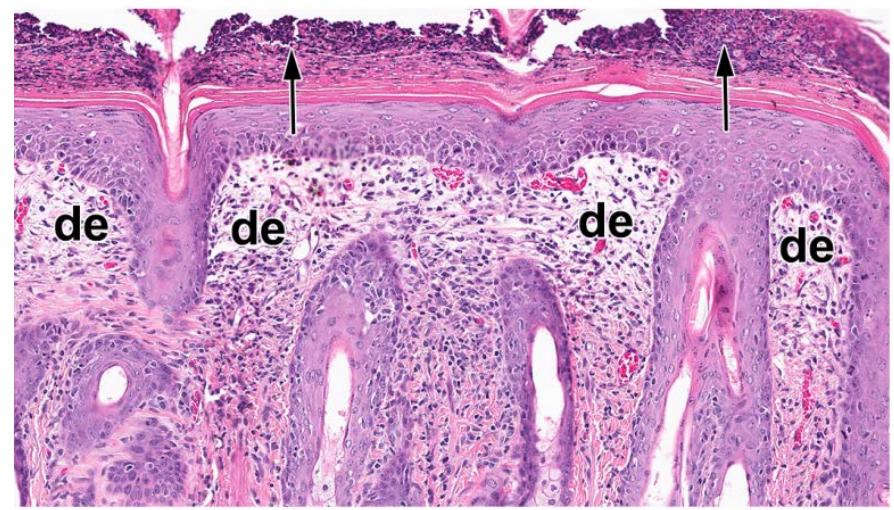

Figure 12. Higher Magnification of Figure 11 (H\&E)

Note degenerate neutrophils within the hyperplastic keratin layer (arrows) and infiltrates of inflammatory cells within the dermis (de). 


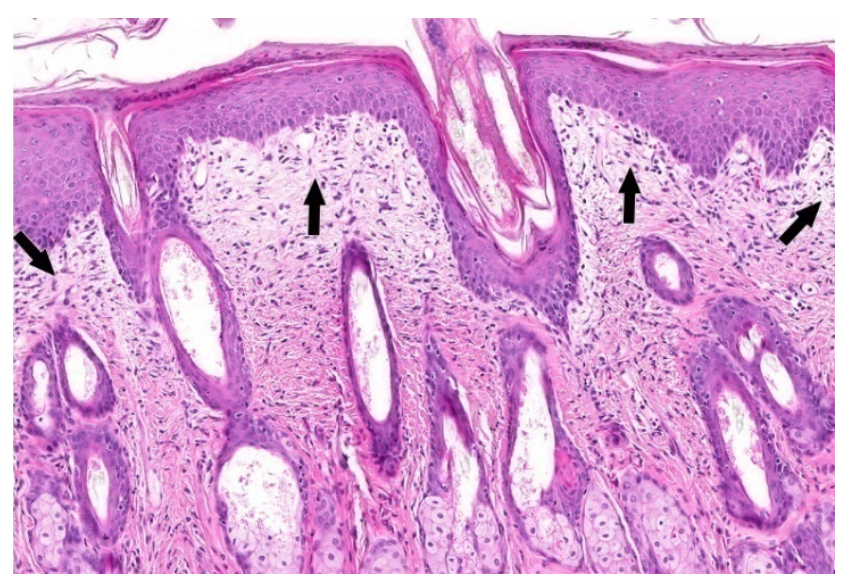

Figure 13. Dermal Fibrosis in the Skin (Site of Application) of a Female F344/N Rat Administered $100 \%$ Cedarwood Oil Dermally for Three Months (H\&E)

Note the fibrotic tissue within the papillary dermis (arrows).

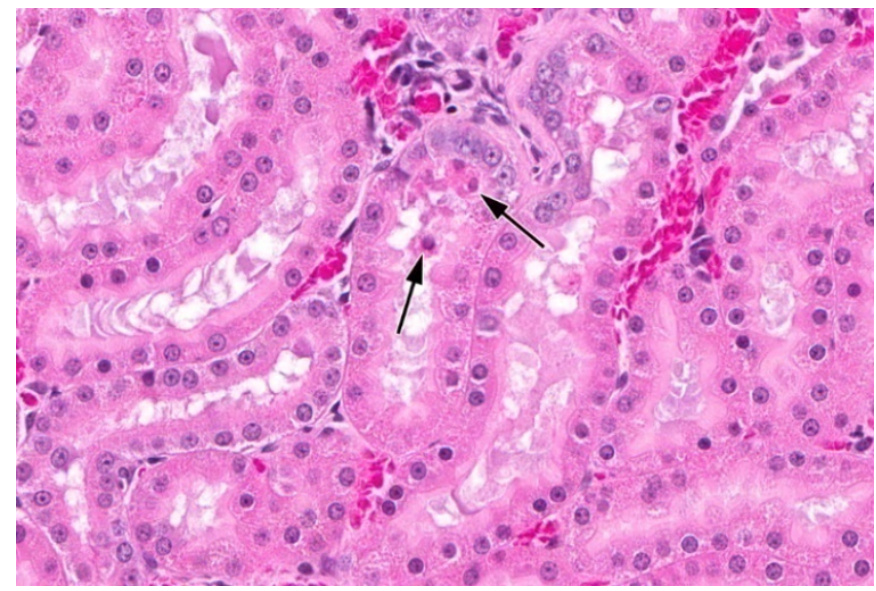

Figure 14. Renal Tubule Degeneration in the Kidney of a Male F344/N Rat Administered 100\% Cedarwood Oil Dermally for Three Months (H\&E)

Note sloughed, shrunken, degenerate epithelial cells within the lumen of a renal tubule (arrows). 


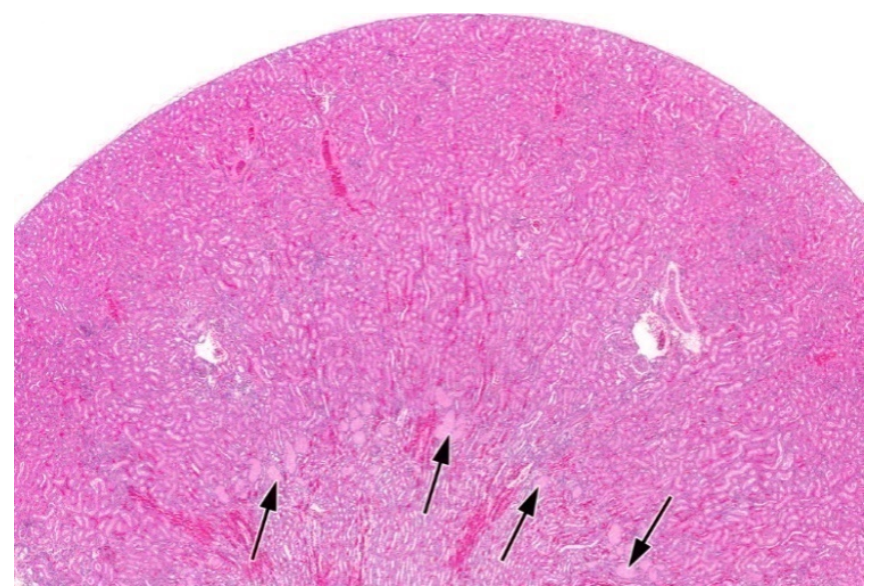

Figure 15. Granular Casts in the Kidney of a Male F344/N Rat Administered 100\% Cedarwood Oil Dermally for Three Months (H\&E)

The renal tubules along the corticomedullary junction (arrows) are occluded and distended by eosinophilic, granular material (casts).

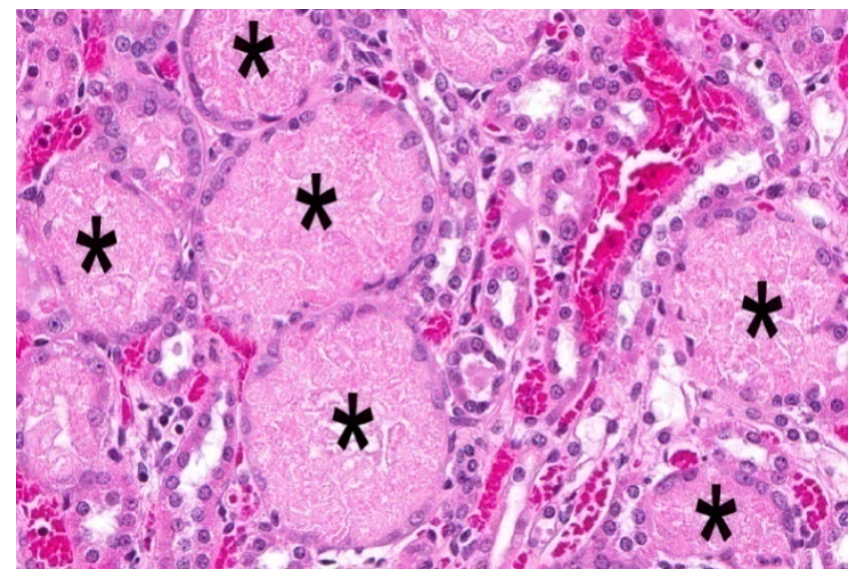

Figure 16. Higher Magnification of Figure 15 Showing Several Renal Tubules that are Occluded and Distended by Eosinophilic, Granular Casts (Asterisks) (H\&E) 


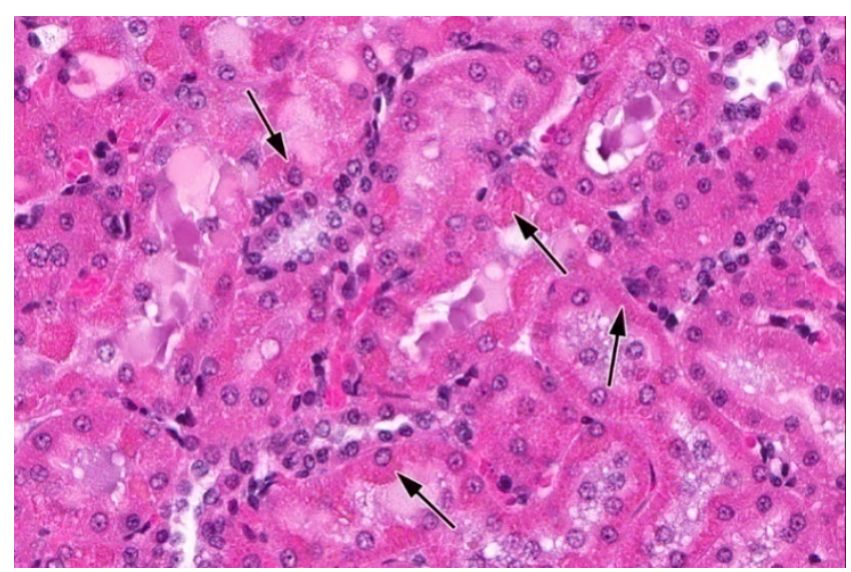

Figure 17. Normal Kidney of a Vehicle Control Male F344/N Rat in the Three-month Dermal Study of Cedarwood Oil Showing Uniformly Fine, Eosinophilic (Hyaline) Droplets (Arrows) within the Cytoplasm of Several Renal Tubule Epithelial Cells (H\&E)

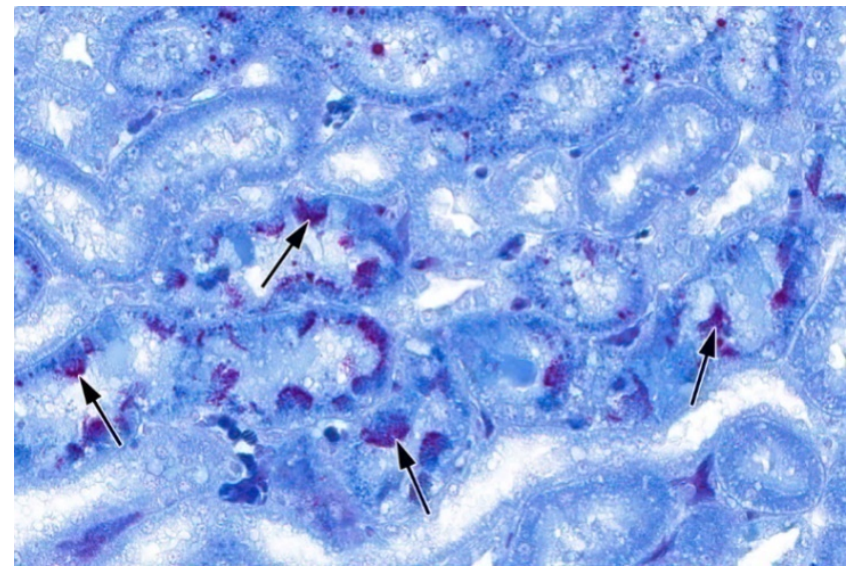

Figure 18. Normal Kidney of a Vehicle Control Male F344/N Rat in the Three-month Dermal Study of Cedarwood Oil Stained with the Mallory-Heidenhain Stain (Mallory-Heidenhain)

This special stain for protein highlights the morphology of the fine, eosinophilic (hyaline) droplets (arrows) within the cytoplasm of several renal tubule epithelial cells. 


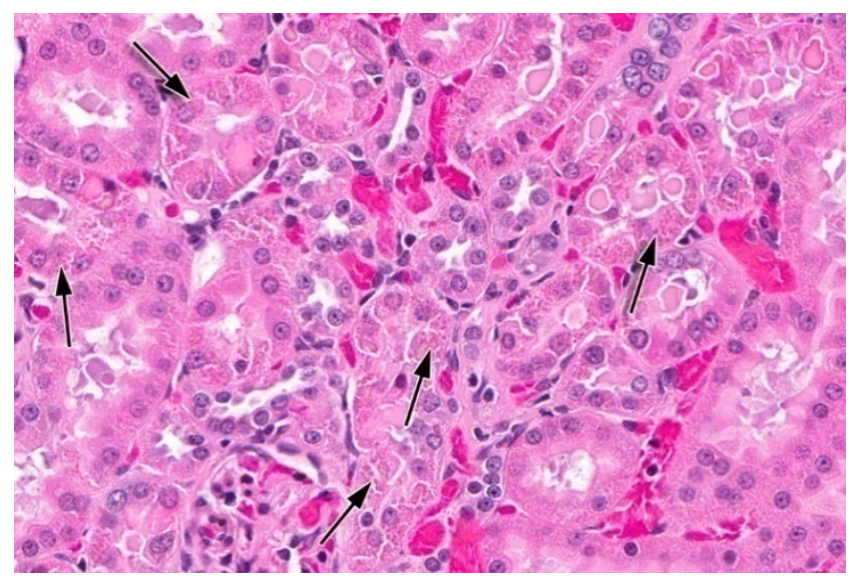

Figure 19. Kidney of a Male F344/N Rat Administered 100\% Cedarwood Oil Dermally for Three Months (H\&E)

Compared to Figure 17, there are larger, variable-sized, round to irregular eosinophilic (hyaline) droplets (arrows) within the cytoplasm of several renal tubule epithelial cells.

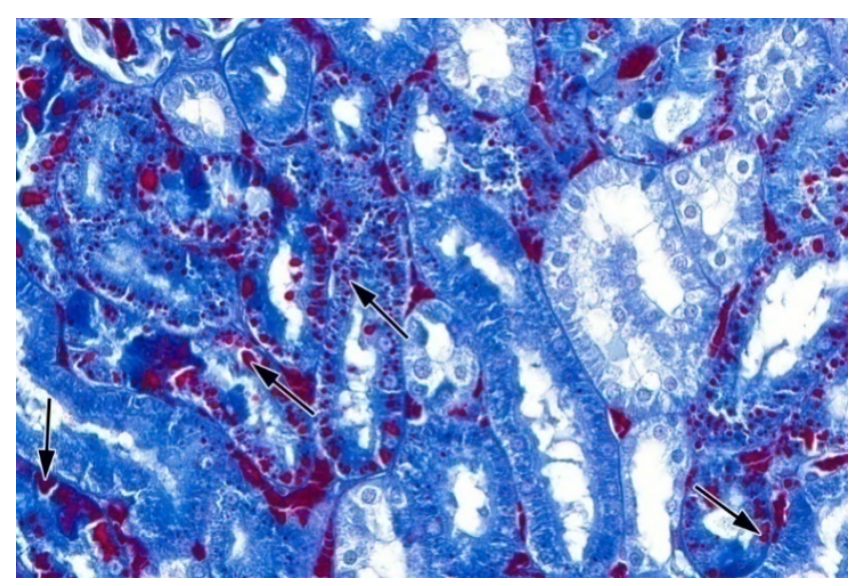

Figure 20. Kidney of a Male F344/N Rat Administered 100\% Cedarwood Oil Dermally for Three Months Stained with the Mallory-Heidenhain Stain for Protein (Mallory-Heidenhain)

Compared to Figure 18, note the morphology of the larger, variable-sized, round to irregular eosinophilic (hyaline) droplets (arrows) within the cytoplasm of several renal tubule epithelial cells. 


\section{Discussion}

Virginia cedarwood oil has widespread use as a fragrance in personal and household products and as an active ingredient in the cedar balls and wooden blocks that are used as moth and bug repellants; the alcohols and terpenes from cedarwood oil have been considered Generally Recognized As Safe by the FDA as a food additive ${ }^{5 ; 15 ; 25}$. As a result of increasing widespread human exposure and the lack of toxicity data, cedarwood oil was nominated by the National Cancer Institute for subchronic toxicity studies. Given the widespread use and large production volume of Virginia cedarwood oil (hereafter referred to as cedarwood oil), this cedarwood oil product was chosen as the test article for the studies in this report. The dermal route of exposure was chosen for the current studies based on the pattern of use in humans. Due to a lack of information on the levels of exposure in the literature, the concentrations selected for these studies were untreated control; $0 \%$ (vehicle control), 6.25\%, 12.5\%, 25\%, or 50\% (with 95\% ethanol as the vehicle); and 100\% (neat; the highest dose possible) cedarwood oil. The untreated control group was included in addition to the $0 \%$ vehicle control group, because the $100 \%$ cedarwood oil dosing solution contained no dosing vehicle (i.e., 95\% ethanol). These applied concentrations corresponded to approximately 31.25 to $500 \mathrm{mg}$ cedarwood oil/kg body weight in the rat and 125 to $2,000 \mathrm{mg} / \mathrm{kg}$ in the mouse. The main toxicity targets of cedarwood oil were the skin at the site of application and the kidney.

Dosing with cedarwood oil for 3 months in rats resulted in severe skin lesions (e.g., irritation, thickening, and ulceration of the skin) at the site of application in all dosed groups, which resulted in the early termination of two male rats in the $100 \%$ group. Due to reduced survival of mice in the $100 \%$ groups and the increased incidences and severities of skin lesions at lower doses, mice appeared to be more sensitive to dermal application of cedarwood oil than rats. Though the mice appear to be more sensitive, this could be attributed to the application of a greater amount of the test article, resulting in an overall higher equivalent $\mathrm{mg} / \mathrm{kg}$ dose. There was evidence of general treatment-related increases in absolute and/or relative kidney weights in the male rats. Additionally, there were general treatment-related decreases in absolute thymus weights in both sexes of both species.

During the 3-month studies, the most significant toxic response to cedarwood oil administration occurred in the skin at the site of application in rats and mice. In general, this was accompanied by microscopic lesions of minimal to moderate severities in the rats and moderate to marked severities in the mice and included epidermal hyperplasia, hyperkeratosis, and ulceration. There were also significant increases in the incidences of hair follicle and sebaceous gland hyperplasia in male and female rats in most dosed groups, and considerable increases in the incidences and severities of the lesions in mice. Incidences of chronic active inflammation increased with increasing dose in the rats and were graded minimal to mild; incidences and severities of this lesion were greater in mice than rats. Chronic active inflammation was characterized by the infiltration of neutrophils and macrophages into the dermis with occasional extensions into the hypodermis. Most data reported from studies of skin irritation or sensitization resulting from cedarwood oil exposure are conflicting and limited because of the low number of subjects evaluated. The majority of the studies testing the potential for skin irritation or sensitivity following acute exposure to cedarwood oil used low concentrations and did not find sensitization or irritation in the small numbers of animals or humans tested ${ }^{11 ; 30 ; 56}$. However, some of the studies did show that application of full strength cedarwood oil to rabbits for 24 hours induced 
moderate skin irritation ${ }^{11}$. In humans, a study examining the skin irritation potential of cedarwood oil was performed over a 24- to 72-hour period and found no evidence of skin irritation in the following groups: $0.2 \%$ (148 subjects), 2.5\% (30 subjects), or 20\% (29 subjects) $)^{32}$.

In the current studies, there were multiple indications of renal injury following dermal administration of cedarwood oil. The 3-month dermal treatment resulted in dose-dependent increases in relative kidney weights in both male and female rats. In male rats, administration of cedarwood oil resulted in the accumulation of hyaline droplets within the epithelial cells of the proximal tubules; incidences and severities of the lesion increased with increasing dose.

Exacerbation of the dose-related formation and accumulation of these hyaline droplets was further verified by Mallory-Heidenhain staining. Additionally, there were pronounced granular casts within the luminal compartment of the renal tubules along the corticomedullary junction. The granular casts formed as a result of the accumulation of cellular debris within the tubules, and their presence indicated prior injury and death of the renal tubule epithelium. There was also evidence of significant renal tubule degeneration in male rats at the higher doses, which was characterized by cellular swelling, mild hypereosinophilia, and sloughing of the renal cortical tubule epithelial cells. Although the incidences of renal tubule degeneration increased with increasing dose, the lesions were subtle and given minimal severity grades in all groups. Spontaneous chronic progressive nephropathy occurs commonly in the kidneys of male, but not female, F344/N rats, and evidence of treatment-related nephropathy can be established if there is a dose-dependent increase in the severities of the lesion. In the current study, nephropathy was characterized by the presence of renal tubule epithelial regeneration foci that increased in severity in the $50 \%$ and $100 \%$ groups.

The incidences of these nonneoplastic kidney lesions may be related to $\alpha 2 \mathrm{u}$-globulin nephropathy, a renal syndrome that specifically occurs in male F344/N rats and has been linked to the occurrence of tubular neoplasms ${ }^{57}$. This syndrome is characterized by several key histologic events that are thought to be secondary to toxicity, and include multifocal tubule regeneration, tubule protein casts, thickening of the tubule and glomerular basement membrane, interstitial fibrosis, and chronic inflammatory cell infiltration ${ }^{58}$. This mechanism has been demonstrated in 3-month studies with several structurally diverse chemicals, including $\alpha$-pinene, decalin, and propylene glycol mono-t-butyl ether ${ }^{58}$; the incidences and severities of these histologic lesions following cedarwood oil exposure were not as marked as with these other compounds. The lesions observed in the current study meet some of the criteria for $\alpha 2 u$-globulinassociated nephropathy in male rat renal carcinogenesis established by USEPA ${ }^{59}$ and the International Agency for Research on Cancer ${ }^{60}$. However, some of the other criteria used by these Agencies, such as measurement of $\alpha 2 \mathrm{u}$-globulin within the hyaline droplets, were not investigated in the current study. Though the possibility of an $\alpha 2 \mathrm{u}$-globulin mechanism of renal toxicity exists, the occurrence of these effects was limited to the two highest doses (50\% and $100 \%$ ) tested in the current study. There were also increases in kidney weights in female mice, indicating the possibility for another mechanism of toxicity.

In the current studies, there was some indication of a potential liver effect from administration of cedarwood oil in both rats and mice. Significant liver effects were more pronounced in mice, which could be attributed to the mice receiving a higher dose on a $\mathrm{mg} / \mathrm{kg}$ basis. There were significant increases in relative liver weights at higher doses in male and female rats, whereas all dosed groups of mice had increases in relative liver weights. Chemical-induced increased liver 
weight has been associated with induction of drug-metabolizing enzymes, and is not uncommon in toxicologic studies. Drug-metabolizing enzymes such as the cytochrome P450s are often associated with liver weight increases greater than $20 \%$ and with evidence of hepatocellular hypertrophy, although hypertrophy may not always be present ${ }^{61}$. Cedrene, a major chemical constituent of cedarwood oil, has been shown in vivo to produce substantive increases in ethylmorphine $\mathrm{N}$-demethylase activities and cytochrome P450 content in comparison to controls, with minimal differences due to routes of administration ${ }^{62}$. Another study exhibited that animals housed on cedar shavings had increased incidences of spontaneous tumors of the liver as well as a highly significant reduction in barbiturate sleeping time, an indication of the induction of liver drug metabolizing enzymes including cytochrome P450 ${ }^{63}$. Conversely, in more recent in vitro studies, the constituents cedrol, $\beta$-cedrene, and thujopsene were found to inhibit the activities of CYP2B6 and CYP3A4 in human liver microsomes ${ }^{64}$. Additionally, in the current study, microscopic evaluation of hepatocytes within male and female mice revealed increased incidences and severities of glycogen depletion at all doses greater than $6.25 \%$ that generally increased with increasing dose. Hepatocyte glycogen depletion was characterized by the lack of large, coalescing, perinuclear clear spaces within the hepatocyte cytoplasm in the dosed animals compared to the controls. Glycogen storage in hepatocytes acts as a cellular energy reserve, and in fasting conditions, these glycogen stores may be depleted. Hepatocyte glycogen depletion in the mice administered cedarwood oil may be related to the decrease in body weight and reduced food intake, which is supported by the inverse relationship between the decreased body weights and depletion of their glycogen stores.

Significantly increased incidences of nonneoplastic lesions occurred in the bone marrow, lymph nodes, and spleen of most dosed groups of mice. In the bone marrow, this occurred in the incidences of myeloid cell hyperplasia in all dosed groups of mice, except for $6.25 \%$ females. Lymphoid hyperplasia occurred in both the mandibular and axillary lymph nodes, however, lymphoid hyperplasia in the axillary lymph nodes occurred only in the $100 \%$ group. Significantly increased incidences and severities of splenic hematopoietic cell proliferation occurred in all dosed groups of mice. These effects are indicative of an inflammatory reaction to the dermal application of cedarwood oil and are considered to be secondary to the severe skin lesions at the application site. This is supported by alterations in clinical pathology parameters, which included increases in leukon alongside decreases in erythron. This increase in the total and differential white blood cell counts (specifically the neutrophils) was consistent with an inflammatory leukogram secondary to the dermal irritation and inflammation. The decreased erythron with no alterations in mean cell volume or mean cell hemoglobin concentration is consistent with an anemia of chronic disease also secondary to the inflammation at the site of application ${ }^{65}$.

Dermal exposure to cedarwood oil resulted in decreases in the absolute and relative thymus weights of rats and mice. On a mg/kg body weight basis, the mice received doses of cedarwood oil that were approximately four times higher than the rats, which could be why the mice had higher incidences of decreased thymus weights across more doses than did the rats. In mice, significant decreases in absolute thymus weights were observed in $25 \%$ and $50 \%$ males and $12.5 \%$ or greater females compared to the vehicle controls. Thymus weight decreases in the male mice were accompanied by thymic atrophy, which consisted of thymocyte depletion in the cortex of the thymus. In rats, absolute thymus weights were significantly decreased in $25 \%$ and $100 \%$ males and $100 \%$ females. The thymus is the most sensitive of the lymphoid organs in response to stress, and stress-related decreases in weight due to lymphocyte depletion may be 
seen within hours of exposure ${ }^{66}$. The thymus effects observed in the current studies in rats and mice are consistent with stress-related organ effects that are a common secondary finding in toxicity studies, and can show dose proportionality.

Cedarwood oil was not found to be mutagenic in any of the Salmonella typhimurium strains tested in vitro or in an in vivo micronucleus test in the peripheral blood of male mice. However, increased micronucleated erythrocyte counts were judged to be equivocal in female mice following 3 months of dermal exposure to cedarwood oil, due to a significant positive trend in the absence of significant dosed group increases relative to controls. In addition, there was no evidence of treatment-related alterations within the micronucleated reticulocyte population in either male or female mice, suggesting that bone marrow toxicity is not induced by dermal application of cedarwood oil.

Under the conditions of the 3-month dermal studies with Virginia cedarwood oil, there were treatment-related lesions in male and female rats and mice. Skin (at the site of application) and kidney were the major targets from administration of cedarwood oil in both rats and mice. Additionally, the liver and the thymus were considered secondary targets of cedarwood oil administration as a result of the skin effects at the site of application in both rats and mice. The most sensitive measures of cedarwood oil administration in each species and sex were: increased incidences of skin (site of application) lesions in male [lowest-observed-effect-level $(\mathrm{LOEL})=12.5 \%$; approximately equivalent to $62.5 \mathrm{mg} / \mathrm{kg}]$ and female $(\mathrm{LOEL}=6.25 \%$; approximately equivalent to $31.25 \mathrm{mg} / \mathrm{kg}$ ) rats and increased incidences of skin (site of application) lesions (LOEL = 6.25\%; approximately equivalent to $124 \mathrm{mg} / \mathrm{kg}$ ) in male and female mice. 


\section{References}

1. The Merck Index, 11th ed. Rahway, NJ: Merck and Company; 1989.

2. Coppen J. Flavours and fragrances of plant origin In: Non-Wood Forest Products, Vol. 1. Rome, Italy: Food and Agriculture Organization of the United Nations (FAO); 1995.

3. Ciesla W. Non-wood forest products from conifers In: Non-Wood Forest Products, Vol. 12. Rome, Italy: Food and Agriculture Organization of the United Nations (FAO); 1998.

4. Merory J. Food flavorings: Composition, manufacture, and use. 2nd ed. Westport, CT: AVI Publishing Company, Inc; 1968.

5. Gerhartz W. Ullmann's encyclopedia of industrial chemistry. Deerfield Beach, FL: VCH Publishers. 1985; p. 220.

6. United States Environmental Protection Agency (USEPA). Reregistration Eligibility Decision (RED): Cedarwood oil. Washington, DC: US Environmental Protection Agency, Office of Prevention, Pesticides and Toxic Substances; 1993. EPA-723-S-93-012.

https://web.archive.org/web/20080619000737/https://www.epa.gov/oppsrrd1/REDs/old_reds/ced arwood_oil.pdf

7. Franz H, Frank R, Rytter M, Haustein UF. Allergic contact dermatitis due to cedarwood oil after dermatoscopy. Contact Dermatitis. 1998; 38(3):182-183. http://dx.doi.org/10.1111/j.16000536.1998.tb05701.X

8. Dunford N, Hiziroglu S, Holcomb R. Effect of age on the distribution of oil in eastern redcedar tree segments. Bioresour Technol. 2007; 98(14):2636-2640.

http://dx.doi.org/10.1016/j.biortech.2006.09.058

9. International Organization for Standardization (ISO). Essential Oils. Oil of cedarwood, Virginian (Juniperus virginiana L) ISO 4724:2004€. 2004.

10. Hazardous Substance Data Bank (HSDB). Cedarwood oil. TOXNET: Toxicology Data Network, National Library of Medicine; 2014. http://toxnet.nlm.nih.gov/hsdb.htm [Accessed: July 2014]

11. Research Institute for Fragrance Materials (RIFM). Fragrance raw materials monographs: Cedarwood oil Virginia. Food Cosmet Toxicol. 1974; 12:845-846.

http://dx.doi.org/10.1016/0015-6264(74)90147-3

12. Food and Drug Administration (FDA). Modification in voluntary filing of cosmetic product ingredient and cosmetic raw material composition statements. Federal Register Vol 57, No 18. Washington, DC; 1992. p. 3128-3130.

13. Cosmetic Ingredient Review (CIR). Final report on the safety assessment of Juniperus communis extract, Juniperus oxycedrus extract, Juniperus oxycedrus tar, Juniperus phoenicea extract, and Juniperus virginiana extract. Int J Toxicol. 2001; 20:41-56. http://dx.doi.org/10.1080/10915810160233758 
14. Craig AM, Karchesy JJ, Blythe LL, del Pilar González-Hernández M, Swan LR. Toxicity studies on western juniper oil (Juniperus occidentalis) and Port-Orford-cedar oil (Chamaecyparis lawsoniana) extracts utilizing local lymph node and acute dermal irritation assays. Toxicol Lett. 2004; 154(3):217-224. http://dx.doi.org/10.1016/j.toxlet.2004.08.004

15. United States Environmental Protection Agency (USEPA). Wood oils and gums summary document. Washington, DC: US Environmental Protection Agency, Office of Prevention, Pesticides and Toxic Substances; 2009. Docket No. EPA-HQ-OPP-2009-0258. https://archive.epa.gov/oppsrrd1/registration_review/web/html/index-291.html

16. Curtis C, Lines J, Ijumba J, Callaghan A, Hill N, Karimzad M. The relative efficacy of repellents against mosquito vectors of disease. Med Vet Entomol. 1987; 1(2):109-119. http://dx.doi.org/10.1111/j.1365-2915.1987.tb00331.x

17. Barnard DR. Repellency of essential oils to mosquitoes (Diptera: Culicidae). J Med Entomol. 1999; 36(5):625-629. http://dx.doi.org/10.1093/jmedent/36.5.625

18. Singh D, Rao S, Tripathi A. Cedarwood oil as a potential insecticidal agent against mosquitoes. Naturwissenschaften. 1984; 71(5):265-266. http://dx.doi.org/10.1007/BF00441340

19. Eller F, Vander Meer R, Behle R, Flor-Weiler L, Palmquist DE. Bioactivity of cedarwood oil and cedrol against arthropod pests. Environ Entomol. 2014; 43(3):762-766.

http://dx.doi.org/10.1603/EN13270

20. Takao Y, Kuriyama I, Yamada T, Mizoguchi H, Yoshida H, Mizushina Y. Antifungal properties of Japanese cedar essential oil from waste wood chips made from used sake barrels. Mol Med Report. 2012; 5(5):1163-1168.

21. Acevedo Z. Abortion in early America. Women Health. 1979; 4(2):159-167. http://dx.doi.org/10.1300/J013v04n02_05

22. Gosselin R, Smith R, Hodge H. Clinical toxicology of commercial products, 5th ed. Baltimore, MD: Williams and Wilkins; 1984.

23. Welch KD, Cook D, Gardner DR, Parsons C, Pfister JA, Panter KE. A comparison of the abortifacient risk of western juniper trees in Oregon. Rangelands. 2013; 35(1):40-44. http://dx.doi.org/10.2111/RANGELANDS-D-12-00056.1

24. National Institute for Occupational Safety and Health (NIOSH). National Occupational Exposure Survey (1981-1983) [unpublished provisional data]. Cincinnati, OH. 1990.

25. Code of Federal Regulations (CFR). 21:§172.515.

26. Code of Federal Regulations (CFR). 40:§152.125.

27. United States Environmental Protection Agency (USEPA). Cedarwood oil; Substance Registry Services (SRS) entry. 2013. https://ofmpub.epa.gov/sor_internet/registry/substreg/searchandretrieve/substancesearch/search.d $\underline{\text { o?details}=\text { displayDetails \&selectedSubstanceId }=16188}$ 
28. Hong JY, Lee BH, Kim TH, Hong J, Lee KM, Yoo SD, Lee HS. GC-MS/MS method for the quantification of $\alpha$-cedrene in rat plasma and its pharmacokinetic application. J Sep Sci. 2013; 36(21-22):3558-3562. http://dx.doi.org/10.1002/jssc.201300828

29. Kim TH, Yoo SD, Lee HS, Lee KM, Seok SH, Kim MG, Jung BH, Kim MG, Shin BS. In vivo absorption and disposition of $\alpha$-cedrene, a sesquiterpene constituent of cedarwood oil, in female and male rats. Drug Metab Pharmacokinet. 2015; 30(2):168-173.

http://dx.doi.org/10.1016/j.dmpk.2014.12.003

30. Frosch P, Pilz B, Andersen KE, Burrows D, Camarasa J, Dooms-Goossens A, Ducombs G, Fuchs T, Hannusksela M, Lachapelle J et al. Patch testing with fragrances: Results of a multicenter study of the European Environmental and Contact Dermatitis Research Group with 48 frequently used constituents of perfumes. Contact Dermatitis. 1995; 33(5):333-342. http://dx.doi.org/10.1111/j.1600-0536.1995.tb02048.x

31. Kligman AM. The identification of contact allergens by human assay: III. The maximization test: A procedure for screening and rating contact sensitizers. J Invest Dermatol. 1966; 47(5):393-409. http://dx.doi.org/10.1038/jid.1966.160

32. Fujii T, Furukawa S, Suzuki S. Studies on compounded perfumes for toilet goods: On the non-irritative compounded perfumes for soaps [in Japanese, English abstract]. Journal of Japan Oil Chemists' Society. 1972; 21:904-908. https://doi.org/10.5650/jos1956.21.904

33. Abifadel R, Mortureux P, Perromat M, Ducombs G, Taier A. Contact sensitivity to flavourings and perfumes in atopic dermatitis. Contact Dermatitis. 1992; 27(1):43-46. http://dx.doi.org/10.1111/j.1600-0536.1992.tb05196.x

34. Belsito D, Bickers D, Bruze M, Calow P, Dagli M, Fryer A, Greim H, Miyachi Y, Saurat J, Sipes I. A toxicological and dermatological assessment of alkyl cyclic ketones when used as fragrance ingredients. Food Chem Toxicol. 2013; 62:S1-S44.

http://dx.doi.org/10.1016/j.fct.2013.09.033

35. Lapczynski A, Isola DA, Christian MS, Diener RM, Api AM. Evaluation of the developmental toxicity of acetyl cedrene. Int J Toxicol. 2006; 25(5):423-428.

http://dx.doi.org/10.1080/10915810600870575

36. Ogata A, Ando H, Kubo Y, Nagasawa A, Ogawa H, Yasuda K, Aoki N. Teratogenicity of thujaplicin in ICR mice. Food Chem Toxicol. 1999; 37(11):1097-1104.

http://dx.doi.org/10.1016/S0278-6915(99)00097-6

37. Adams R. Cedar wood oil analyses and properties In: Linsken H, Jackson J, editors. Modern Methods of Plant Analysis New Series: Essential Oils and Waxes, Vol 12. New York, NY:

Springer-Verlag; 1991. p. 159-173. http://dx.doi.org/10.1007/978-3-642-84023-4_8

38. Adams R. Identification of essential oil components by gas chromatography/quadrupole mass spectroscopy. Carol Stream, IL: Allured Publishing Corporation; 2001.

39. Adams R. Identification of essential oils by ion trap mass spectrometry. San Diego, CA: Academic Press, Inc; 1989. 
40. Maronpot R, Boorman G. Interpretation of rodent hepatocellular proliferative alterations and hepatocellular tumors in chemical safety assessment. Toxicol Pathol. 1982; 10(2):71-78. http://dx.doi.org/10.1177/019262338201000210

41. Boorman GA, Montgomery CA, Jr., Eustis SL, Wolfe MJ, McConnell EE, Hardisty JF. Quality assurance in pathology for rodent carcinogenicity studies. In: Milman HA, Weisburger EK, editors. Handbook of Carcinogen Testing. Park Ridge, NJ: Noyes Publications; 1985. p. 345-357.

42. Gart JJ, Chu KC, Tarone RE. Statistical issues in interpretation of chronic bioassay tests for carcinogenicity. J Natl Cancer Inst. 1979; 62(4):957-974.

43. Dunnett CW. A multiple comparison procedure for comparing several treatments with a control. J Am Stat Assoc. 1955; 50(272):1096-1121. http://dx.doi.org/10.1080/01621459.1955.10501294

44. Williams D. A test for differences between treatment means when several dose levels are compared with a zero dose control. Biometrics. 1971; 27(1):103-117.

http://dx.doi.org/10.2307/2528930

45. Williams D. The comparison of several dose levels with a zero dose control. Biometrics. 1972; 28(2):519-531. http://dx.doi.org/10.2307/2556164

46. Shirley E. A non-parametric equivalent of Williams' test for contrasting increasing dose levels of a treatment. Biometrics. 1977; 33(2):386-389. http://dx.doi.org/10.2307/2529789

47. Williams D. A note on Shirley's nonparametric test for comparing several dose levels with a zero-dose control. Biometrics. 1986; 42(1):183-186. http://dx.doi.org/10.2307/2531254

48. Dunn OJ. Multiple comparisons using rank sums. Technometrics. 1964; 6(3):241-252. http://dx.doi.org/10.1080/00401706.1964.10490181

49. Jonckheere A. A distribution-free k-sample test against ordered alternatives. Biometrika. 1954; 41:133-145. http://dx.doi.org/10.1093/biomet/41.1-2.133

50. Dixon W, Massey F. Introduction to statistical analysis. 2nd ed. New York, NY: McGraw Hill Book Company Inc; 1957. http://dx.doi.org/10.2307/2332898

51. Girard D, Sager D. The use of Markov chains to detect subtle variation in reproductive cycling. Biometrics. 1987; 43(1):225-234. http://dx.doi.org/10.2307/2531963

52. Wilcoxon F. Individual comparisons by ranking methods. Biometrics Bull. 1945; 1(6):80-83. http://dx.doi.org/10.2307/3001968

53. Code of Federal Regulations (CFR). 21:Part 58.

54. Zeiger E, Anderson B, Haworth S, Lawlor T, Mortelmans K. Salmonella mutagenicity tests. 5. Results from the testing of 311 chemicals. Environ Mol Mutagen. 1992; 19:2-141. http://dx.doi.org/10.1002/em.2850190603

55. MacGregor JT, Wehr CM, Henika PR, Shelby MD. The in vivo erythrocyte micronucleus test: Measurement at steady state increases assay efficiency and permits integration with toxicity 
studies. Fundam Appl Toxicol. 1990; 14(3):513-522. http://dx.doi.org/10.1016/0272$\underline{0590(90) 90255-\mathrm{I}}$

56. Roe F, Field WE. Chronic toxicity of essential oils and certain other products of natural origin. Food Cosmet Toxicol. 1965; 3:311-323. http://dx.doi.org/10.1016/S0015-6264(65)80090$\underline{6}$

57. Swenberg JA. Alpha 2u-globulin nephropathy: Review of the cellular and molecular mechanisms involved and their implications for human risk assessment. Environ Health Perspect. 1993; 101(Suppl 6):39. http://dx.doi.org/10.1289/ehp.93101s639

58. Doi AM, Hill G, Seely J, Hailey JR, Kissling G, Bucher JR. a2u-Globulin nephropathy and renal tumors in National Toxicology Program studies. Toxicol Pathol. 2007; 35(4):533-540. http://dx.doi.org/10.1080/01926230701338941

59. United States Environmental Protection Agency (USEPA). Alpha 2u-globulin: Association with chemically induced renal toxicity and neoplasia in the male rat. Washington, DC: U.S. Environmental Protection Agency, prepared for the Risk Assessment Forum; 1991. EPA/625/391/019F.

60. Intermational Agency for Research on Cancer (IARC). Species differences in thyroid, kidney and urinary bladder carcinogenesis: IARC Scientific Publications No. 147. Lyon, France: Intermational Agency for Research on Cancer (IARC); 1999.

61. Amacher D, Schomaker S, Burkhardt J. The relationship among microsomal enzyme induction, liver weight and histological change in rat toxicology studies. Food Chem Toxicol. 1998; 36(9-10):831-839. http://dx.doi.org/10.1016/S0278-6915(98)00066-0

62. Hashimoto M, Davis DC, Gillette JR. Effect of different routes of administration of cedrene on hepatic drug metabolism. Biochem Pharmacol. 1972; 21(10):1514-1517. http://dx.doi.org/10.1016/0006-2952(72)90377-2

63. Sabine JR. Exposure to an environment containing the aromatic red cedar, Juniperus virginiana: Procarcinogenic, enzyme-inducing and insecticidal effects. Toxicology. 1975; 5(2):221-235. http://dx.doi.org/10.1016/0300-483X(75)90119-5

64. Jeong H-U, Kwon S-S, Kong TY, Kim JH, Lee HS. Inhibitory effects of cedrol, $\beta$-cedrene, and thujopsene on cytochrome P450 enzyme activities in human liver microsomes. J Toxicol Environ Health, A. 2014; 77(22-24):1522-1532.

http://dx.doi.org/10.1080/15287394.2014.955906

65. Weiss G, Goodnough LT. Anemia of chronic disease. N Engl J Med. 2005; 352(10):10111023. http://dx.doi.org/10.1056/NEJMra041809

66. Everds NE, Snyder PW, Bailey KL, Bolon B, Creasy DM, Foley GL, Rosol TJ, Sellers T. Interpreting stress responses during routine toxicity studies: A review of the biology, impact, and assessment. Toxicol Pathol. 2013; 41(4):560-614. http://dx.doi.org/10.1177/0192623312466452

67. Bellanato J, Hidalgo A. Infrared analysis of essential oils. London, UK: Heyden and Son Limited; 1971. 


\section{Cedarwood Oil, NTP TOX 86}

68. Sigma-Aldrich Chemical Company. The Aldrich library of infrared spectra: Vol 3, spectrum 66B. Milwaukee, WI: Sigma-Aldrich Chemical Company; 1981. 


\section{Appendix A. Summary of Nonneoplastic Lesions in Rats and Mice}

\section{Tables}

Table A-1. Summary of the Incidence of Nonneoplastic Lesions in Male Rats in the Three-month Dermal Study of Cedarwood Oil

Table A-2. Summary of the Incidence of Nonneoplastic Lesions in Female Rats in the Three-month Dermal Study of Cedarwood Oil

Table A-3. Summary of the Incidence of Nonneoplastic Lesions in Male Mice in the Three-month Dermal Study of Cedarwood Oil

Table A-4. Summary of the Incidence of Nonneoplastic Lesions in Female Mice in the Three-month Dermal Study of Cedarwood Oil 
Table A-1. Summary of the Incidence of Nonneoplastic Lesions in Male Rats in the Three-month Dermal Study of Cedarwood Oil ${ }^{\mathrm{a}}$

\begin{tabular}{|c|c|c|c|c|c|c|c|}
\hline & $\begin{array}{l}\text { Untreated } \\
\text { Control }\end{array}$ & $\begin{array}{l}\text { Vehicle } \\
\text { Control }\end{array}$ & $6.25 \%$ & $12.5 \%$ & $25 \%$ & $50 \%$ & $100 \%$ \\
\hline \multicolumn{8}{|l|}{ Disposition Summary } \\
\hline Animals initially in study & 10 & 10 & 10 & 10 & 10 & 10 & 10 \\
\hline \multicolumn{8}{|l|}{ Early deaths } \\
\hline Moribund & - & - & - & - & - & - & 2 \\
\hline \multicolumn{8}{|l|}{ Survivors } \\
\hline Terminal euthanasia & 10 & 10 & 10 & 10 & 10 & 10 & 8 \\
\hline $\begin{array}{l}\text { Animals examined } \\
\text { microscopically }\end{array}$ & 10 & 10 & 10 & 10 & 10 & 10 & 10 \\
\hline \multicolumn{8}{|l|}{ Alimentary System } \\
\hline Esophagus & $(10)$ & $(10)$ & $(0)$ & $(0)$ & $(0)$ & $(0)$ & (10) \\
\hline Intestine large, cecum & $(10)$ & $(10)$ & $(0)$ & $(0)$ & $(0)$ & (0) & $(10)$ \\
\hline Intestine large, colon & (10) & $(10)$ & $(0)$ & (0) & $(0)$ & (0) & (10) \\
\hline Intestine large, rectum & $(10)$ & $(10)$ & $(0)$ & $(0)$ & $(0)$ & $(0)$ & (10) \\
\hline Parasite metazoan & $1(10 \%)$ & - & - & - & - & - & $1(10 \%)$ \\
\hline Intestine small, duodenum & $(10)$ & $(10)$ & $(0)$ & $(0)$ & (0) & $(0)$ & (10) \\
\hline Intestine small, ileum & $(10)$ & (10) & $(0)$ & $(0)$ & $(0)$ & (0) & (10) \\
\hline Intestine small, jejunum & $(10)$ & $(10)$ & $(0)$ & (0) & $(0)$ & $(0)$ & $(10)$ \\
\hline Liver & $(10)$ & $(10)$ & $(10)$ & $(10)$ & $(10)$ & $(10)$ & (10) \\
\hline $\begin{array}{l}\text { Hematopoietic cell } \\
\text { proliferation }\end{array}$ & - & $1(10 \%)$ & - & $1(10 \%)$ & - & $1(10 \%)$ & - \\
\hline $\begin{array}{l}\text { Hepatodiaphragmatic } \\
\text { nodule }\end{array}$ & $1(10 \%)$ & $1(10 \%)$ & - & - & - & - & - \\
\hline Inflammation & $8(80 \%)$ & $8(80 \%)$ & $10(100 \%)$ & $10(100 \%)$ & $7(70 \%)$ & $7(70 \%)$ & $9(90 \%)$ \\
\hline Necrosis, focal & - & - & - & - & - & - & $1(10 \%)$ \\
\hline Pancreas & $(10)$ & $(10)$ & $(0)$ & $(0)$ & $(0)$ & $(0)$ & $(10)$ \\
\hline Atrophy & - & $1(10 \%)$ & - & - & - & - & $1(10 \%)$ \\
\hline $\begin{array}{l}\text { Infiltration cellular, } \\
\text { mononuclear cell }\end{array}$ & $4(40 \%)$ & $5(50 \%)$ & - & - & - & - & $3(30 \%)$ \\
\hline Salivary glands & $(10)$ & (10) & $(0)$ & $(0)$ & $(0)$ & $(0)$ & (10) \\
\hline $\begin{array}{l}\text { Submandibular gland, } \\
\text { vacuolization } \\
\text { cytoplasmic }\end{array}$ & 5 (50\%) & $2(20 \%)$ & - & - & - & - & $4(40 \%)$ \\
\hline Stomach, forestomach & $(10)$ & (10) & $(0)$ & $(0)$ & $(0)$ & $(0)$ & (10) \\
\hline Stomach, glandular & (10) & $(10)$ & $(0)$ & $(0)$ & $(0)$ & $(0)$ & $(10)$ \\
\hline Glands, ectasia & - & $2(20 \%)$ & - & - & - & - & - \\
\hline
\end{tabular}




\begin{tabular}{|c|c|c|c|c|c|c|c|}
\hline & $\begin{array}{l}\text { Untreated } \\
\text { Control }\end{array}$ & $\begin{array}{l}\text { Vehicle } \\
\text { Control }\end{array}$ & $6.25 \%$ & $12.5 \%$ & $25 \%$ & $50 \%$ & $100 \%$ \\
\hline \multicolumn{8}{|l|}{ Cardiovascular System } \\
\hline Blood vessel & $(10)$ & $(10)$ & $(0)$ & $(0)$ & (0) & $(0)$ & (10) \\
\hline Heart & (10) & (10) & (0) & (0) & (0) & (0) & (10) \\
\hline Cardiomyopathy & $10(100 \%)$ & $10(100 \%)$ & - & - & - & - & $10(100 \%)$ \\
\hline Epicardium, hyperplasia & - & - & - & - & - & - & $1(10 \%)$ \\
\hline \multicolumn{8}{|l|}{ Endocrine System } \\
\hline Adrenal cortex & $(10)$ & $(10)$ & $(10)$ & $(10)$ & (10) & $(10)$ & (10) \\
\hline Angiectasis & $4(40 \%)$ & $2(20 \%)$ & - & - & - & - & - \\
\hline Adrenal medulla & $(10)$ & $(10)$ & $(0)$ & $(0)$ & $(0)$ & (0) & (10) \\
\hline Islets, pancreatic & $(10)$ & $(10)$ & $(0)$ & $(0)$ & $(0)$ & $(0)$ & $(10)$ \\
\hline $\begin{array}{l}\text { Infiltration cellular, } \\
\text { mononuclear cell }\end{array}$ & $1(10 \%)$ & $1(10 \%)$ & - & - & - & - & - \\
\hline Parathyroid gland & (9) & (9) & $(0)$ & $(0)$ & $(0)$ & $(0)$ & $(10)$ \\
\hline Pituitary gland & $(10)$ & (10) & (0) & (0) & $(0)$ & $(0)$ & (10) \\
\hline Cyst & - & $1(10 \%)$ & - & - & - & - & - \\
\hline Thyroid gland & $(10)$ & $(10)$ & (10) & (10) & $(10)$ & (10) & (10) \\
\hline Ultimobranchial cyst & - & - & $2(20 \%)$ & - & - & - & - \\
\hline \multicolumn{8}{|l|}{ General Body System } \\
\hline None & - & - & - & - & - & - & - \\
\hline \multicolumn{8}{|l|}{ Genital System } \\
\hline Epididymis & $(10)$ & $(10)$ & $(0)$ & $(0)$ & (0) & $(0)$ & (10) \\
\hline $\begin{array}{l}\text { Infiltration cellular, } \\
\text { mononuclear cell }\end{array}$ & - & $1(10 \%)$ & - & - & - & - & - \\
\hline Inflammation & $1(10 \%)$ & $2(20 \%)$ & - & - & - & - & $2(20 \%)$ \\
\hline Preputial gland & (10) & $(10)$ & $(0)$ & $(0)$ & $(0)$ & $(0)$ & (10) \\
\hline $\begin{array}{l}\text { Inflammation, focal, } \\
\text { chronic }\end{array}$ & - & $1(10 \%)$ & - & - & - & - & $3(30 \%)$ \\
\hline Prostate & $(10)$ & $(10)$ & $(0)$ & $(0)$ & $(0)$ & $(0)$ & (10) \\
\hline Inflammation & $2(20 \%)$ & - & - & - & - & - & - \\
\hline Seminal vesicle & $(10)$ & (10) & $(0)$ & (1) & $(0)$ & $(0)$ & (10) \\
\hline Testes & $(10)$ & $(10)$ & $(0)$ & (1) & $(0)$ & $(0)$ & $(10)$ \\
\hline $\begin{array}{l}\text { Germinal epithelium, } \\
\text { right, atrophy }\end{array}$ & - & - & - & $1(100 \%)$ & - & - & - \\
\hline \multicolumn{8}{|l|}{ Hematopoietic System } \\
\hline Bone marrow & $(10)$ & $(10)$ & $(10)$ & $(10)$ & $(10)$ & $(10)$ & (10) \\
\hline Hyperplasia & - & - & - & - & - & $1(10 \%)$ & 7 (70\%) \\
\hline
\end{tabular}




\begin{tabular}{|c|c|c|c|c|c|c|c|}
\hline & $\begin{array}{l}\text { Untreated } \\
\text { Control }\end{array}$ & $\begin{array}{l}\text { Vehicle } \\
\text { Control }\end{array}$ & $6.25 \%$ & $12.5 \%$ & $25 \%$ & $50 \%$ & $100 \%$ \\
\hline Lymph node, mesenteric & $(10)$ & $(10)$ & $(0)$ & $(0)$ & $(0)$ & $(0)$ & $(10)$ \\
\hline Spleen & $(10)$ & $(10)$ & $(0)$ & $(0)$ & $(0)$ & $(0)$ & $(10)$ \\
\hline $\begin{array}{l}\text { Hematopoietic cell } \\
\text { proliferation }\end{array}$ & - & $1(10 \%)$ & - & - & - & - & - \\
\hline Thymus & $(10)$ & $(10)$ & (0) & $(0)$ & $(0)$ & $(0)$ & $(10)$ \\
\hline \multicolumn{8}{|l|}{ Integumentary System } \\
\hline Mammary gland & (10) & $(10)$ & $(0)$ & $(0)$ & $(0)$ & (0) & $(10)$ \\
\hline Skin & $(10)$ & $(10)$ & $(10)$ & $(10)$ & $(10)$ & $(10)$ & (10) \\
\hline $\begin{array}{l}\text { Hair follicle, site of } \\
\text { application } \\
\text { hyperplasia }\end{array}$ & - & - & - & - & $9(90 \%)$ & $10(100 \%)$ & $9(90 \%)$ \\
\hline $\begin{array}{l}\text { Sebaceous gland, } \\
\text { site of application, } \\
\text { hyperplasia }\end{array}$ & - & - & - & - & $9(90 \%)$ & $10(100 \%)$ & 10 (100\%) \\
\hline $\begin{array}{l}\text { Site of application, } \\
\text { inflammation, } \\
\text { chronic active }\end{array}$ & - & - & $1(10 \%)$ & $4(40 \%)$ & $9(90 \%)$ & $10(100 \%)$ & $10(100 \%)$ \\
\hline $\begin{array}{l}\text { Site of application, } \\
\text { dermis, fibrosis }\end{array}$ & - & - & - & - & 7 (70\%) & $10(100 \%)$ & $10(100 \%)$ \\
\hline $\begin{array}{l}\text { Site of application, } \\
\text { epidermis, } \\
\text { hyperkeratosis }\end{array}$ & - & - & - & $1(10 \%)$ & $7(70 \%)$ & $10(100 \%)$ & $10(100 \%)$ \\
\hline $\begin{array}{l}\text { Site of application, } \\
\text { epidermis, hyperplasia }\end{array}$ & - & - & $2(20 \%)$ & $4(40 \%)$ & $10(100 \%)$ & 10 (100\%) & $9(90 \%)$ \\
\hline $\begin{array}{l}\text { Site of application, } \\
\text { epidermis, ulcer }\end{array}$ & - & - & - & $1(10 \%)$ & $1(10 \%)$ & 7 (70\%) & $8(80 \%)$ \\
\hline \multicolumn{8}{|l|}{ Musculoskeletal System } \\
\hline Bone & $(10)$ & $(10)$ & $(0)$ & $(0)$ & $(0)$ & $(0)$ & $(10)$ \\
\hline \multicolumn{8}{|l|}{ Nervous System } \\
\hline Brain & $(10)$ & $(10)$ & $(0)$ & $(0)$ & $(0)$ & $(0)$ & $(10)$ \\
\hline \multicolumn{8}{|l|}{ Respiratory System } \\
\hline Lung & $(10)$ & $(10)$ & $(0)$ & $(0)$ & $(0)$ & $(0)$ & $(10)$ \\
\hline Hemorrhage & - & - & - & - & - & - & $1(10 \%)$ \\
\hline $\begin{array}{l}\text { Infiltration cellular, } \\
\text { histiocyte }\end{array}$ & $2(20 \%)$ & $1(10 \%)$ & - & - & - & - & $2(20 \%)$ \\
\hline Inflammation & $2(20 \%)$ & $5(50 \%)$ & - & - & - & - & $4(40 \%)$ \\
\hline Metaplasia, osseous & $5(50 \%)$ & $5(50 \%)$ & - & - & - & - & $4(40 \%)$ \\
\hline $\begin{array}{r}\text { Pigmentation, } \\
\text { hemosiderin }\end{array}$ & - & - & - & - & - & - & $1(10 \%)$ \\
\hline
\end{tabular}




\begin{tabular}{|c|c|c|c|c|c|c|c|}
\hline & $\begin{array}{l}\text { Untreated } \\
\text { Control }\end{array}$ & $\begin{array}{l}\text { Vehicle } \\
\text { Control }\end{array}$ & $6.25 \%$ & $12.5 \%$ & $25 \%$ & $50 \%$ & $100 \%$ \\
\hline $\begin{array}{l}\text { Serosa, inflammation, } \\
\text { granulomatous }\end{array}$ & - & - & - & - & - & - & $1(10 \%)$ \\
\hline Nose & (10) & (10) & $(0)$ & (0) & $(0)$ & $(0)$ & (10) \\
\hline $\begin{array}{l}\text { Inflammation, } \\
\text { chronic active }\end{array}$ & - & - & - & - & - & - & $2(20 \%)$ \\
\hline Trachea & (10) & (10) & $(0)$ & (0) & $(0)$ & $(0)$ & (10) \\
\hline \multicolumn{8}{|l|}{ Special Senses System } \\
\hline Eye & (10) & (10) & $(0)$ & (0) & $(0)$ & $(0)$ & $(10)$ \\
\hline Harderian gland & (10) & (10) & $(0)$ & (0) & $(0)$ & $(0)$ & $(10)$ \\
\hline \multicolumn{8}{|l|}{ Urinary System } \\
\hline Kidney & (10) & $(10)$ & $(10)$ & (10) & (10) & (10) & $(10)$ \\
\hline $\begin{array}{l}\text { Accumulation, } \\
\text { hyaline droplet }\end{array}$ & - & - & - & - & $10(100 \%)$ & 10 (100\%) & $10(100 \%)$ \\
\hline $\begin{array}{l}\text { Infiltration cellular, } \\
\text { mononuclear cell }\end{array}$ & $1(10 \%)$ & $1(10 \%)$ & - & - & $1(10 \%)$ & - & $1(10 \%)$ \\
\hline Mineralization & 9 (90\%) & $4(40 \%)$ & 7 (70\%) & $9(90 \%)$ & $8(80 \%)$ & $8(80 \%)$ & 8 (80\%) \\
\hline Nephropathy & $10(100 \%)$ & 10 (100\%) & 10 (100\%) & $10(100 \%)$ & 10 (100\%) & 10 (100\%) & $10(100 \%)$ \\
\hline $\begin{array}{l}\text { Renal tubule, casts } \\
\text { granular }\end{array}$ & - & - & - & - & $5(50 \%)$ & $10(100 \%)$ & $10(100 \%)$ \\
\hline $\begin{array}{l}\text { Renal tubule, } \\
\text { degeneration }\end{array}$ & $2(20 \%)$ & $4(40 \%)$ & $5(50 \%)$ & $6(60 \%)$ & 7 (70\%) & 10 (100\%) & $10(100 \%)$ \\
\hline Urinary bladder & (10) & (10) & $(0)$ & (0) & $(0)$ & $(0)$ & (10) \\
\hline $\begin{array}{l}\text { Infiltration cellular, } \\
\text { mononuclear cell }\end{array}$ & $1(10 \%)$ & $1(10 \%)$ & - & - & - & - & $1(10 \%)$ \\
\hline $\begin{array}{l}\text { Serosa, mineralization, } \\
\text { focal }\end{array}$ & - & - & - & - & - & - & $1(10 \%)$ \\
\hline
\end{tabular}


Table A-2. Summary of the Incidence of Nonneoplastic Lesions in Female Rats in the Three-month Dermal Study of Cedarwood Oil ${ }^{\mathrm{a}}$

\begin{tabular}{|c|c|c|c|c|c|c|c|}
\hline & $\begin{array}{l}\text { Untreated } \\
\text { Control }\end{array}$ & $\begin{array}{l}\text { Vehicle } \\
\text { Control }\end{array}$ & $6.25 \%$ & $12.5 \%$ & $25 \%$ & $50 \%$ & $100 \%$ \\
\hline \multicolumn{8}{|l|}{ Disposition Summary } \\
\hline Animals initially in study & 10 & 10 & 10 & 10 & 10 & 10 & 10 \\
\hline \multicolumn{8}{|l|}{ Survivors } \\
\hline Terminal euthanasia & 10 & 10 & 10 & 10 & 10 & 10 & 10 \\
\hline $\begin{array}{l}\text { Animals examined } \\
\text { microscopically }\end{array}$ & 10 & 10 & 10 & 10 & 10 & 10 & 10 \\
\hline \multicolumn{8}{|l|}{ Alimentary System } \\
\hline Esophagus & $(10)$ & $(10)$ & $(0)$ & (0) & $(0)$ & $(0)$ & $(10)$ \\
\hline Intestine large, cecum & $(10)$ & $(10)$ & $(0)$ & $(0)$ & $(0)$ & $(0)$ & $(10)$ \\
\hline Intestine large, colon & $(10)$ & $(10)$ & $(0)$ & $(0)$ & $(0)$ & $(0)$ & $(10)$ \\
\hline Intestine large, rectum & $(10)$ & $(10)$ & $(0)$ & $(0)$ & $(0)$ & $(0)$ & $(10)$ \\
\hline Parasite metazoan & - & $1(10 \%)$ & - & - & - & - & - \\
\hline Intestine small, duodenum & (10) & $(10)$ & $(0)$ & $(0)$ & $(0)$ & $(0)$ & $(10)$ \\
\hline Intestine small, ileum & $(10)$ & $(10)$ & $(0)$ & $(0)$ & $(0)$ & $(0)$ & $(10)$ \\
\hline Intestine small, jejunum & $(10)$ & $(10)$ & $(0)$ & $(0)$ & $(0)$ & $(0)$ & $(10)$ \\
\hline Liver & $(10)$ & $(10)$ & $(10)$ & $(10)$ & (10) & $(10)$ & $(10)$ \\
\hline $\begin{array}{l}\text { Hematopoietic cell } \\
\text { proliferation }\end{array}$ & $2(20 \%)$ & - & - & - & - & - & - \\
\hline $\begin{array}{l}\text { Hepatodiaphragmatic } \\
\text { nodule }\end{array}$ & $2(20 \%)$ & $1(10 \%)$ & - & - & - & - & - \\
\hline Inflammation & $10(100 \%)$ & $9(90 \%)$ & $10(100 \%)$ & $9(90 \%)$ & $8(80 \%)$ & $5(50 \%)$ & 7 (70\%) \\
\hline Mesentery & $(0)$ & $(0)$ & (1) & $(0)$ & $(0)$ & $(0)$ & $(0)$ \\
\hline Mineralization & - & - & $1(100 \%)$ & - & - & - & - \\
\hline Necrosis & - & - & $1(100 \%)$ & - & - & - & - \\
\hline $\begin{array}{l}\text { Fat, inflammation, } \\
\text { granulomatous, } \\
\text { chronic active }\end{array}$ & - & - & $1(100 \%)$ & - & - & - & - \\
\hline Pancreas & $(10)$ & $(10)$ & $(0)$ & $(0)$ & $(0)$ & (0) & $(10)$ \\
\hline Atrophy & - & - & - & - & - & - & $1(10 \%)$ \\
\hline $\begin{array}{l}\text { Infiltration cellular, } \\
\text { mononuclear cell }\end{array}$ & 7 (70\%) & $4(40 \%)$ & - & - & - & - & $3(30 \%)$ \\
\hline Salivary glands & (10) & (10) & $(0)$ & $(0)$ & (10) & (10) & (10) \\
\hline $\begin{array}{l}\text { Sublingual gland, } \\
\text { ectopic tissue }\end{array}$ & - & - & - & - & - & - & $1(10 \%)$ \\
\hline $\begin{array}{l}\text { Submandibular gland } \\
\text { ectopic tissue }\end{array}$ & - & - & - & - & - & - & $1(10 \%)$ \\
\hline
\end{tabular}


Cedarwood Oil, NTP TOX 86

\begin{tabular}{|c|c|c|c|c|c|c|c|}
\hline & $\begin{array}{c}\text { Untreated } \\
\text { Control }\end{array}$ & $\begin{array}{l}\text { Vehicle } \\
\text { Control }\end{array}$ & $6.25 \%$ & $12.5 \%$ & $25 \%$ & $50 \%$ & $100 \%$ \\
\hline $\begin{array}{l}\text { Submandibular gland, } \\
\text { vacuolization } \\
\text { cytoplasmic }\end{array}$ & $3(30 \%)$ & $4(40 \%)$ & - & - & - & - & $1(10 \%)$ \\
\hline Stomach, forestomach & (10) & (10) & $(0)$ & (0) & $(0)$ & $(0)$ & (10) \\
\hline Stomach, glandular & $(10)$ & $(10)$ & $(0)$ & $(0)$ & $(0)$ & $(0)$ & $(10)$ \\
\hline \multicolumn{8}{|l|}{ Cardiovascular System } \\
\hline Blood vessel & (10) & (10) & $(0)$ & $(0)$ & $(0)$ & $(0)$ & (10) \\
\hline Heart & $(10)$ & (10) & $(0)$ & $(0)$ & $(0)$ & $(0)$ & (10) \\
\hline Cardiomyopathy & $10(100 \%)$ & $9(90 \%)$ & - & - & - & - & $10(100 \%)$ \\
\hline $\begin{array}{l}\text { Inflammation, } \\
\text { chronic active }\end{array}$ & $1(10 \%)$ & - & - & - & - & - & - \\
\hline \multicolumn{8}{|l|}{ Endocrine System } \\
\hline Adrenal cortex & (10) & (10) & $(0)$ & (0) & $(0)$ & $(0)$ & (10) \\
\hline Infiltration cellular & $1(10 \%)$ & - & - & - & - & - & - \\
\hline $\begin{array}{l}\text { Infiltration cellular, } \\
\text { mononuclear cell }\end{array}$ & - & $1(10 \%)$ & - & - & - & - & - \\
\hline Mineralization & - & $1(10 \%)$ & - & - & - & - & - \\
\hline Adrenal medulla & (10) & (10) & $(0)$ & $(0)$ & $(0)$ & $(0)$ & (10) \\
\hline Islets, pancreatic & (10) & $(10)$ & (0) & $(0)$ & $(0)$ & $(0)$ & (10) \\
\hline Parathyroid gland & (9) & (9) & $(0)$ & $(0)$ & $(0)$ & $(0)$ & (10) \\
\hline Pituitary gland & $(10)$ & (10) & $(0)$ & $(0)$ & $(0)$ & $(0)$ & (10) \\
\hline Cyst & $2(20 \%)$ & $2(20 \%)$ & - & - & - & - & $1(10 \%)$ \\
\hline Thyroid gland & (10) & (10) & (10) & (10) & (10) & (10) & (10) \\
\hline $\begin{array}{l}\text { Infiltration cellular, } \\
\text { mononuclear cell }\end{array}$ & - & $2(20 \%)$ & - & - & - & - & $1(10 \%)$ \\
\hline Ultimobranchial cyst & - & $3(30 \%)$ & $2(20 \%)$ & - & $3(30 \%)$ & $3(30 \%)$ & $2(20 \%)$ \\
\hline \multicolumn{8}{|l|}{ General Body System } \\
\hline None & - & - & - & - & - & - & - \\
\hline \multicolumn{8}{|l|}{ Genital System } \\
\hline Clitoral gland & (10) & $(10)$ & $(0)$ & (0) & $(0)$ & $(0)$ & (10) \\
\hline $\begin{array}{l}\text { Infiltration cellular, } \\
\text { mononuclear cell }\end{array}$ & $1(10 \%)$ & - & - & - & - & - & - \\
\hline $\begin{array}{l}\text { Inflammation, focal, } \\
\text { chronic active }\end{array}$ & 1 (10\%) & - & - & - & - & - & - \\
\hline $\begin{array}{l}\text { Inflammation, } \\
\text { chronic active }\end{array}$ & 1 (10\%) & - & - & - & - & - & - \\
\hline Ovary & (10) & (10) & $(0)$ & (0) & $(0)$ & $(0)$ & (10) \\
\hline Left, cyst & 1 (10\%) & - & - & - & - & - & - \\
\hline
\end{tabular}




\begin{tabular}{|c|c|c|c|c|c|c|c|}
\hline & $\begin{array}{l}\text { Untreated } \\
\text { Control }\end{array}$ & $\begin{array}{l}\text { Vehicle } \\
\text { Control }\end{array}$ & $6.25 \%$ & $12.5 \%$ & $25 \%$ & $50 \%$ & $100 \%$ \\
\hline Uterus & (10) & $(10)$ & $(0)$ & $(0)$ & $(0)$ & $(0)$ & $(10)$ \\
\hline \multicolumn{8}{|l|}{ Hematopoietic System } \\
\hline Bone marrow & $(10)$ & (10) & (9) & $(10)$ & $(10)$ & $(10)$ & $(10)$ \\
\hline Hyperplasia & - & - & - & - & $2(20 \%)$ & $2(20 \%)$ & 7 (70\%) \\
\hline Lymph node, mesenteric & $(10)$ & $(10)$ & $(0)$ & (0) & $(0)$ & (0) & $(10)$ \\
\hline Spleen & $(10)$ & $(10)$ & $(0)$ & $(0)$ & $(0)$ & $(0)$ & $(10)$ \\
\hline Thymus & $(10)$ & $(10)$ & $(0)$ & $(0)$ & $(0)$ & $(0)$ & $(10)$ \\
\hline \multicolumn{8}{|l|}{ Integumentary System } \\
\hline Mammary gland & $(10)$ & $(10)$ & $(0)$ & $(0)$ & $(0)$ & $(0)$ & $(10)$ \\
\hline Skin & $(10)$ & $(10)$ & $(10)$ & $(10)$ & $(10)$ & $(10)$ & (10) \\
\hline $\begin{array}{l}\text { Hair follicle, } \\
\text { site of application, } \\
\text { hyperplasia }\end{array}$ & - & - & - & $1(10 \%)$ & $9(90 \%)$ & $10(100 \%)$ & $10(100 \%)$ \\
\hline $\begin{array}{l}\text { Sebaceous gland, } \\
\text { site of application, } \\
\text { hyperplasia }\end{array}$ & - & - & - & $4(40 \%)$ & $9(90 \%)$ & $10(100 \%)$ & $10(100 \%)$ \\
\hline $\begin{array}{l}\text { Site of application, } \\
\text { inflammation, } \\
\text { chronic active }\end{array}$ & - & - & - & $7(70 \%)$ & $10(100 \%)$ & $10(100 \%)$ & $10(100 \%)$ \\
\hline $\begin{array}{l}\text { Site of application, } \\
\text { dermis, fibrosis }\end{array}$ & - & - & - & $1(10 \%)$ & $7(70 \%)$ & $8(80 \%)$ & $10(100 \%)$ \\
\hline $\begin{array}{l}\text { Site of application, } \\
\text { epidermis, } \\
\text { hyperkeratosis }\end{array}$ & - & - & $1(10 \%)$ & $5(50 \%)$ & $10(100 \%)$ & $10(100 \%)$ & $10(100 \%)$ \\
\hline $\begin{array}{l}\text { Site of application, } \\
\text { epidermis, } \\
\text { hyperplasia }\end{array}$ & - & - & $4(40 \%)$ & $7(70 \%)$ & $10(100 \%)$ & $10(100 \%)$ & $10(100 \%)$ \\
\hline $\begin{array}{l}\text { Site of application, } \\
\text { epidermis, ulcer }\end{array}$ & - & - & - & $1(10 \%)$ & $1(10 \%)$ & $4(40 \%)$ & $10(100 \%)$ \\
\hline \multicolumn{8}{|l|}{ Musculoskeletal System } \\
\hline Bone & $(10)$ & $(10)$ & $(0)$ & $(0)$ & $(0)$ & $(0)$ & $(10)$ \\
\hline \multicolumn{8}{|l|}{ Nervous System } \\
\hline Brain & $(10)$ & $(10)$ & $(0)$ & $(0)$ & $(0)$ & $(0)$ & $(10)$ \\
\hline \multicolumn{8}{|l|}{ Respiratory System } \\
\hline Lung & $(10)$ & $(10)$ & (0) & $(0)$ & $(0)$ & $(0)$ & $(10)$ \\
\hline $\begin{array}{l}\text { Infiltration cellular, } \\
\text { histiocyte }\end{array}$ & - & $1(10 \%)$ & - & - & - & - & $1(10 \%)$ \\
\hline Inflammation & $3(30 \%)$ & $2(20 \%)$ & - & - & - & - & $2(20 \%)$ \\
\hline Metaplasia, osseous & $1(10 \%)$ & $1(10 \%)$ & - & - & - & - & - \\
\hline
\end{tabular}




\begin{tabular}{|c|c|c|c|c|c|c|c|}
\hline & $\begin{array}{c}\text { Untreated } \\
\text { Control }\end{array}$ & $\begin{array}{l}\text { Vehicle } \\
\text { Control }\end{array}$ & $6.25 \%$ & $12.5 \%$ & $25 \%$ & $50 \%$ & $100 \%$ \\
\hline Nose & $(10)$ & $(10)$ & $(0)$ & $(0)$ & $(0)$ & $(0)$ & $(10)$ \\
\hline $\begin{array}{l}\text { Inflammation, } \\
\text { chronic active }\end{array}$ & - & - & - & - & - & - & $1(10 \%)$ \\
\hline $\begin{array}{r}\text { Vacuolization } \\
\text { cytoplasmic }\end{array}$ & - & $1(10 \%)$ & - & - & - & - & - \\
\hline Trachea & $(10)$ & $(10)$ & $(0)$ & $(0)$ & $(0)$ & $(0)$ & $(10)$ \\
\hline $\begin{array}{l}\text { Infiltration cellular, } \\
\text { mononuclear cell }\end{array}$ & $1(10 \%)$ & - & - & - & - & - & - \\
\hline \multicolumn{8}{|l|}{ Special Senses System } \\
\hline Eye & $(10)$ & $(10)$ & $(0)$ & $(0)$ & $(0)$ & $(0)$ & $(10)$ \\
\hline Harderian gland & $(10)$ & (10) & $(0)$ & $(0)$ & (0) & $(0)$ & $(10)$ \\
\hline Infiltration cellular & - & - & - & - & - & - & $1(10 \%)$ \\
\hline \multicolumn{8}{|l|}{ Urinary System } \\
\hline Kidney & $(10)$ & $(10)$ & $(0)$ & $(0)$ & $(0)$ & $(0)$ & $(10)$ \\
\hline Infarct, focal, chronic & $1(10 \%)$ & - & - & - & - & - & - \\
\hline Mineralization & $5(50 \%)$ & $5(50 \%)$ & - & - & - & - & $6(60 \%)$ \\
\hline Nephropathy & - & $1(10 \%)$ & - & - & - & - & $1(10 \%)$ \\
\hline Urinary bladder & (10) & $(10)$ & $(0)$ & $(0)$ & $(0)$ & $(0)$ & $(10)$ \\
\hline $\begin{array}{l}\text { Infiltration cellular, } \\
\text { mononuclear cell }\end{array}$ & $5(50 \%)$ & $2(20 \%)$ & - & - & - & - & - \\
\hline
\end{tabular}

Table A-3. Summary of the Incidence of Nonneoplastic Lesions in Male Mice in the Three-month Dermal Study of Cedarwood Oil ${ }^{\mathrm{a}}$

\begin{tabular}{|c|c|c|c|c|c|c|c|}
\hline & $\begin{array}{l}\text { Untreated } \\
\text { Control }\end{array}$ & $\begin{array}{l}\text { Vehicle } \\
\text { Control }\end{array}$ & $6.25 \%$ & $12.5 \%$ & $25 \%$ & $50 \%$ & $100 \%$ \\
\hline \multicolumn{8}{|l|}{ Disposition Summary } \\
\hline Animals initially in study & 10 & 10 & 10 & 10 & 10 & 10 & 10 \\
\hline \multicolumn{8}{|l|}{ Early deaths } \\
\hline Moribund & - & - & - & 1 & - & 1 & 10 \\
\hline \multicolumn{8}{|l|}{ Survivors } \\
\hline Terminal euthanasia & 10 & 10 & 10 & 9 & 10 & 9 & - \\
\hline $\begin{array}{l}\text { Animals examined } \\
\text { microscopically }\end{array}$ & 10 & 10 & 10 & 10 & 10 & 10 & 10 \\
\hline \multicolumn{8}{|l|}{ Alimentary System } \\
\hline Esophagus & $(10)$ & (10) & $(0)$ & (1) & $(0)$ & $(10)$ & (10) \\
\hline Gallbladder & $(10)$ & $(10)$ & (0) & (1) & $(0)$ & $(10)$ & (10) \\
\hline Intestine large, cecum & $(10)$ & (10) & $(0)$ & (1) & $(0)$ & (10) & (10) \\
\hline
\end{tabular}


Cedarwood Oil, NTP TOX 86

\begin{tabular}{|c|c|c|c|c|c|c|c|}
\hline & $\begin{array}{l}\text { Untreated } \\
\text { Control }\end{array}$ & $\begin{array}{l}\text { Vehicle } \\
\text { Control }\end{array}$ & $6.25 \%$ & $12.5 \%$ & $25 \%$ & $50 \%$ & $100 \%$ \\
\hline Intestine large, colon & $(10)$ & $(10)$ & $(0)$ & (1) & $(0)$ & $(10)$ & $(10)$ \\
\hline Intestine large, rectum & $(10)$ & $(10)$ & (0) & (1) & $(0)$ & $(10)$ & $(10)$ \\
\hline Intestine small, duodenum & $(10)$ & $(10)$ & $(0)$ & $(1)$ & $(0)$ & $(10)$ & $(10)$ \\
\hline Intestine small, ileum & $(10)$ & (10) & $(0)$ & (1) & $(0)$ & $(10)$ & (10) \\
\hline Intestine small, jejunum & $(10)$ & $(10)$ & $(0)$ & (1) & $(0)$ & $(10)$ & $(10)$ \\
\hline Liver & (10) & $(10)$ & $(10)$ & $(10)$ & $(10)$ & $(10)$ & $(10)$ \\
\hline $\begin{array}{l}\text { Hematopoietic cell } \\
\text { proliferation }\end{array}$ & - & - & - & - & - & $1(10 \%)$ & - \\
\hline Infarct & - & - & - & - & - & - & $1(10 \%)$ \\
\hline $\begin{array}{l}\text { Inflammation, } \\
\text { chronic active }\end{array}$ & $8(80 \%)$ & 7 (70\%) & $6(60 \%)$ & $8(80 \%)$ & 7 (70\%) & $2(20 \%)$ & $1(10 \%)$ \\
\hline Necrosis, focal & - & $1(10 \%)$ & - & - & - & $1(10 \%)$ & $2(20 \%)$ \\
\hline $\begin{array}{l}\text { Hepatocyte, } \\
\text { depletion glycogen }\end{array}$ & - & - & - & $6(60 \%)$ & 9 (90\%) & $10(100 \%)$ & $10(100 \%)$ \\
\hline Mesentery & (0) & $(0)$ & $(0)$ & (0) & $(0)$ & (1) & $(0)$ \\
\hline Fat, fibrosis & - & - & - & - & - & $1(100 \%)$ & - \\
\hline Fat, necrosis & - & - & - & - & - & $1(100 \%)$ & - \\
\hline Pancreas & $(10)$ & $(10)$ & $(0)$ & (1) & $(0)$ & $(10)$ & $(10)$ \\
\hline Salivary glands & $(10)$ & $(10)$ & (0) & (1) & $(0)$ & $(10)$ & $(10)$ \\
\hline $\begin{array}{l}\text { Inflammation, } \\
\text { chronic active }\end{array}$ & $1(10 \%)$ & - & - & - & - & - & - \\
\hline Stomach, forestomach & $(10)$ & $(10)$ & (0) & (1) & $(0)$ & $(10)$ & $(10)$ \\
\hline Stomach, glandular & (10) & $(10)$ & $(0)$ & (1) & $(0)$ & $(10)$ & (10) \\
\hline \multicolumn{8}{|l|}{ Cardiovascular System } \\
\hline Blood vessel & $(10)$ & $(10)$ & $(0)$ & (1) & $(0)$ & $(10)$ & $(10)$ \\
\hline Heart & $(10)$ & $(10)$ & $(0)$ & (1) & $(0)$ & $(10)$ & $(10)$ \\
\hline \multicolumn{8}{|l|}{ Endocrine System } \\
\hline Adrenal cortex & $(10)$ & $(10)$ & $(0)$ & (1) & $(0)$ & $(10)$ & (10) \\
\hline $\begin{array}{l}\text { Accessory adrenal } \\
\text { cortical nodule }\end{array}$ & $1(10 \%)$ & $2(20 \%)$ & - & - & - & $2(20 \%)$ & - \\
\hline Adrenal medulla & $(10)$ & $(10)$ & $(0)$ & (1) & $(0)$ & (10) & (10) \\
\hline Islets, pancreatic & $(10)$ & $(10)$ & $(0)$ & (1) & $(0)$ & $(10)$ & $(10)$ \\
\hline Parathyroid gland & (10) & (9) & $(0)$ & (1) & $(0)$ & (10) & $(10)$ \\
\hline Cyst & - & $1(11 \%)$ & - & - & - & - & $1(10 \%)$ \\
\hline Pituitary gland & $(10)$ & $(10)$ & $(0)$ & (1) & $(0)$ & $(10)$ & (10) \\
\hline Thyroid gland & $(10)$ & $(10)$ & $(0)$ & (1) & $(0)$ & (10) & $(10)$ \\
\hline Ectopic thymus & $1(10 \%)$ & - & - & - & - & - & - \\
\hline
\end{tabular}


Cedarwood Oil, NTP TOX 86

\begin{tabular}{|c|c|c|c|c|c|c|c|}
\hline & $\begin{array}{l}\text { Untreated } \\
\text { Control }\end{array}$ & $\begin{array}{l}\text { Vehicle } \\
\text { Control }\end{array}$ & $6.25 \%$ & $12.5 \%$ & $25 \%$ & $50 \%$ & $100 \%$ \\
\hline Follicle, degeneration & - & - & - & - & - & $1(10 \%)$ & $2(20 \%)$ \\
\hline \multicolumn{8}{|l|}{ General Body System } \\
\hline None & - & - & - & - & - & - & - \\
\hline \multicolumn{8}{|l|}{ Genital System } \\
\hline Coagulating gland & $(10)$ & (10) & $(0)$ & $(1)$ & $(0)$ & $(10)$ & (10) \\
\hline Epididymis & (10) & $(10)$ & (0) & $(1)$ & $(0)$ & $(10)$ & $(10)$ \\
\hline Preputial gland & $(10)$ & $(10)$ & $(0)$ & (1) & $(0)$ & $(10)$ & (10) \\
\hline Prostate & (10) & (10) & (0) & (1) & $(0)$ & $(10)$ & (10) \\
\hline Seminal vesicle & $(10)$ & $(10)$ & (0) & (1) & $(0)$ & $(10)$ & $(10)$ \\
\hline Testes & $(10)$ & $(10)$ & $(0)$ & (1) & $(0)$ & (10) & $(10)$ \\
\hline \multicolumn{8}{|l|}{ Hematopoietic System } \\
\hline Bone marrow & $(10)$ & $(10)$ & $(10)$ & $(10)$ & $(10)$ & $(10)$ & $(10)$ \\
\hline Myeloid cell, hyperplasia & - & - & $5(50 \%)$ & $10(100 \%)$ & $10(100 \%)$ & $10(100 \%)$ & $10(100 \%)$ \\
\hline Lymph node & $(0)$ & $(0)$ & $(0)$ & $(0)$ & $(0)$ & $(0)$ & (9) \\
\hline $\begin{array}{l}\text { Axillary, hyperplasia, } \\
\text { lymphoid }\end{array}$ & - & - & - & - & - & - & $9(100 \%)$ \\
\hline Lymph node, mandibular & $(10)$ & $(10)$ & $(10)$ & $(10)$ & (9) & $(10)$ & $(10)$ \\
\hline Hyperplasia, lymphoid & - & - & $1(10 \%)$ & $6(60 \%)$ & $5(56 \%)$ & $9(90 \%)$ & $8(80 \%)$ \\
\hline Lymph node, mesenteric & $(10)$ & (10) & $(0)$ & (1) & $(0)$ & $(10)$ & (10) \\
\hline Spleen & (10) & $(10)$ & $(10)$ & $(10)$ & $(10)$ & $(10)$ & $(10)$ \\
\hline $\begin{array}{l}\text { Hematopoietic cell } \\
\text { proliferation }\end{array}$ & - & - & $6(60 \%)$ & $10(100 \%)$ & $10(100 \%)$ & $10(100 \%)$ & $10(100 \%)$ \\
\hline Thymus & (10) & (10) & $(10)$ & $(10)$ & $(10)$ & $(10)$ & $(10)$ \\
\hline Atrophy & - & - & - & - & $5(50 \%)$ & $10(100 \%)$ & $10(100 \%)$ \\
\hline $\begin{array}{l}\text { Ectopic parathyroid } \\
\text { gland }\end{array}$ & - & $1(10 \%)$ & - & - & - & $1(10 \%)$ & - \\
\hline \multicolumn{8}{|l|}{ Integumentary System } \\
\hline Skin & $(10)$ & (9) & $(10)$ & $(10)$ & $(10)$ & $(10)$ & $(10)$ \\
\hline $\begin{array}{l}\text { Hair follicle, } \\
\text { site of application, } \\
\text { dilatation }\end{array}$ & - & - & - & - & - & $1(10 \%)$ & $1(10 \%)$ \\
\hline $\begin{array}{l}\text { Hair follicle, } \\
\text { site of application, } \\
\text { hyperplasia }\end{array}$ & - & - & $10(100 \%)$ & $10(100 \%)$ & $10(100 \%)$ & $10(100 \%)$ & $10(100 \%)$ \\
\hline $\begin{array}{l}\text { Sebaceous gland, } \\
\text { site of application, } \\
\text { hyperplasia }\end{array}$ & - & - & $10(100 \%)$ & $10(100 \%)$ & $10(100 \%)$ & $10(100 \%)$ & $10(100 \%)$ \\
\hline
\end{tabular}


Cedarwood Oil, NTP TOX 86

\begin{tabular}{|c|c|c|c|c|c|c|c|}
\hline & $\begin{array}{c}\text { Untreated } \\
\text { Control }\end{array}$ & $\begin{array}{l}\text { Vehicle } \\
\text { Control }\end{array}$ & $6.25 \%$ & $12.5 \%$ & $25 \%$ & $50 \%$ & $100 \%$ \\
\hline $\begin{array}{l}\text { Site of application, } \\
\text { inflammation, } \\
\text { chronic active }\end{array}$ & - & - & $10(100 \%)$ & $10(100 \%)$ & $10(100 \%)$ & $10(100 \%)$ & $10(100 \%)$ \\
\hline $\begin{array}{l}\text { Site of application, } \\
\text { dermis, fibrosis }\end{array}$ & - & - & $3(30 \%)$ & 10 (100\%) & $10(100 \%)$ & $10(100 \%)$ & $10(100 \%)$ \\
\hline $\begin{array}{l}\text { Site of application, } \\
\text { epidermis, } \\
\text { hyperkeratosis }\end{array}$ & - & - & 7 (70\%) & $10(100 \%)$ & $10(100 \%)$ & $10(100 \%)$ & $10(100 \%)$ \\
\hline $\begin{array}{l}\text { Site of application, } \\
\text { epidermis, } \\
\text { hyperplasia }\end{array}$ & - & - & $10(100 \%)$ & $10(100 \%)$ & $10(100 \%)$ & $10(100 \%)$ & $10(100 \%)$ \\
\hline $\begin{array}{l}\text { Site of application, } \\
\text { epidermis, ulcer }\end{array}$ & - & - & $2(20 \%)$ & $8(80 \%)$ & $10(100 \%)$ & $9(90 \%)$ & $10(100 \%)$ \\
\hline \multicolumn{8}{|l|}{ Musculoskeletal System } \\
\hline Bone & $(10)$ & $(10)$ & $(0)$ & (1) & $(0)$ & (10) & $(10)$ \\
\hline \multicolumn{8}{|l|}{ Nervous System } \\
\hline Brain & $(10)$ & $(10)$ & (0) & (1) & $(0)$ & $(10)$ & $(10)$ \\
\hline \multicolumn{8}{|l|}{ Respiratory System } \\
\hline Lung & $(10)$ & $(10)$ & (0) & (1) & $(0)$ & $(10)$ & $(10)$ \\
\hline Metaplasia, osseous & $1(10 \%)$ & - & - & - & - & - & - \\
\hline Thrombosis & - & $1(10 \%)$ & - & - & - & - & - \\
\hline Nose & $(10)$ & $(10)$ & $(0)$ & (1) & $(0)$ & (10) & (10) \\
\hline Trachea & $(10)$ & $(10)$ & (0) & (1) & $(0)$ & $(10)$ & $(10)$ \\
\hline \multicolumn{8}{|l|}{ Special Senses System } \\
\hline Eye & $(10)$ & $(10)$ & $(0)$ & (1) & $(0)$ & $(10)$ & $(10)$ \\
\hline Harderian gland & $(10)$ & (10) & $(0)$ & (1) & $(0)$ & $(10)$ & (10) \\
\hline \multicolumn{8}{|l|}{ Urinary System } \\
\hline Kidney & $(10)$ & $(10)$ & $(10)$ & $(10)$ & $(10)$ & $(10)$ & $(10)$ \\
\hline $\begin{array}{l}\text { Inflammation, chronic } \\
\text { active }\end{array}$ & - & - & - & - & - & - & $1(10 \%)$ \\
\hline Nephropathy & - & $2(20 \%)$ & - & $1(10 \%)$ & $2(20 \%)$ & $3(30 \%)$ & $5(50 \%)$ \\
\hline Urinary bladder & (10) & $(10)$ & $(0)$ & $(1)$ & $(0)$ & (10) & $(10)$ \\
\hline
\end{tabular}

${ }^{a}$ Number of animals examined microscopically at the site and the number of animals with lesion. 
Table A-4. Summary of the Incidence of Nonneoplastic Lesions in Female Mice in the Three-month Dermal Study of Cedarwood Oil ${ }^{\mathrm{a}}$

\begin{tabular}{|c|c|c|c|c|c|c|c|}
\hline & $\begin{array}{l}\text { Untreated } \\
\text { Control }\end{array}$ & $\begin{array}{l}\text { Vehicle } \\
\text { Control } \\
\end{array}$ & $6.25 \%$ & $12.5 \%$ & $25 \%$ & $50 \%$ & $100 \%$ \\
\hline \multicolumn{8}{|l|}{ Disposition Summary } \\
\hline Animals initially in study & 10 & 10 & 10 & 10 & 10 & 10 & 10 \\
\hline \multicolumn{8}{|l|}{ Early deaths } \\
\hline Moribund & - & - & - & - & - & 1 & 10 \\
\hline \multicolumn{8}{|l|}{ Survivors } \\
\hline Terminal euthanasia & 10 & 10 & 10 & 10 & 10 & 9 & - \\
\hline $\begin{array}{l}\text { Animals examined } \\
\text { microscopically }\end{array}$ & 10 & 10 & 10 & 10 & 10 & 10 & 10 \\
\hline \multicolumn{8}{|l|}{ Alimentary System } \\
\hline Esophagus & $(10)$ & $(10)$ & $(0)$ & $(0)$ & $(0)$ & $(10)$ & $(10)$ \\
\hline Gallbladder & $(10)$ & $(10)$ & $(0)$ & $(0)$ & $(0)$ & $(10)$ & $(10)$ \\
\hline Intestine large, cecum & $(10)$ & (10) & (0) & $(0)$ & $(0)$ & $(10)$ & (10) \\
\hline Intestine large, colon & $(10)$ & $(10)$ & (0) & $(0)$ & $(0)$ & $(10)$ & (10) \\
\hline Intestine large, rectum & $(10)$ & (10) & $(0)$ & (0) & $(0)$ & $(10)$ & $(10)$ \\
\hline Intestine small, duodenum & (10) & (10) & (0) & (0) & $(0)$ & $(10)$ & $(10)$ \\
\hline Intestine small, ileum & (10) & (10) & (0) & $(0)$ & $(0)$ & (10) & (10) \\
\hline Intestine small, jejunum & (10) & $(10)$ & $(0)$ & $(0)$ & $(0)$ & $(10)$ & $(10)$ \\
\hline Diverticulum & - & - & - & - & - & $1(10 \%)$ & - \\
\hline Liver & (10) & (10) & (10) & (10) & (10) & $(10)$ & (10) \\
\hline Infarct & - & - & - & - & - & - & $1(10 \%)$ \\
\hline $\begin{array}{l}\text { Inflammation, } \\
\text { chronic active }\end{array}$ & $10(100 \%)$ & $10(100 \%)$ & $8(80 \%)$ & 9 (90\%) & $9(90 \%)$ & $10(100 \%)$ & $8(80 \%)$ \\
\hline Tension, lipidosis & - & - & - & - & - & $1(10 \%)$ & - \\
\hline $\begin{array}{l}\text { Hepatocyte, } \\
\text { depletion glycogen }\end{array}$ & - & - & - & $5(50 \%)$ & $9(90 \%)$ & $10(100 \%)$ & $10(100 \%)$ \\
\hline Hepatocyte, necrosis & - & - & - & - & - & - & $1(10 \%)$ \\
\hline Pancreas & $(10)$ & $(10)$ & $(0)$ & $(0)$ & $(0)$ & $(10)$ & $(10)$ \\
\hline Salivary glands & $(10)$ & $(10)$ & $(0)$ & $(0)$ & $(0)$ & $(10)$ & $(10)$ \\
\hline Stomach, forestomach & $(10)$ & $(10)$ & $(0)$ & $(0)$ & $(0)$ & $(10)$ & $(10)$ \\
\hline Stomach, glandular & (10) & $(10)$ & $(0)$ & $(0)$ & $(0)$ & $(10)$ & (10) \\
\hline Mineralization & - & $1(10 \%)$ & - & - & - & - & - \\
\hline \multicolumn{8}{|l|}{ Cardiovascular System } \\
\hline Heart & $(10)$ & $(10)$ & $(0)$ & $(0)$ & $(0)$ & $(10)$ & $(10)$ \\
\hline \multicolumn{8}{|l|}{ Endocrine System } \\
\hline Adrenal cortex & (10) & $(10)$ & $(0)$ & $(0)$ & $(0)$ & $(10)$ & $(10)$ \\
\hline
\end{tabular}




\begin{tabular}{|c|c|c|c|c|c|c|c|}
\hline & $\begin{array}{c}\text { Untreated } \\
\text { Control }\end{array}$ & $\begin{array}{l}\text { Vehicle } \\
\text { Control }\end{array}$ & $6.25 \%$ & $12.5 \%$ & $25 \%$ & $50 \%$ & $100 \%$ \\
\hline $\begin{array}{l}\text { Accessory adrenal } \\
\text { cortical nodule }\end{array}$ & $1(10 \%)$ & - & - & - & - & - & - \\
\hline Adrenal medulla & $(10)$ & $(10)$ & $(0)$ & $(0)$ & (0) & (10) & $(10)$ \\
\hline Islets, pancreatic & (10) & (10) & $(0)$ & (0) & $(0)$ & (10) & (10) \\
\hline Parathyroid gland & (9) & (9) & $(0)$ & $(0)$ & (0) & (8) & (9) \\
\hline Pituitary gland & $(10)$ & $(10)$ & $(0)$ & $(0)$ & (0) & (10) & $(10)$ \\
\hline Thyroid gland & (10) & (10) & (0) & (0) & (0) & (10) & (10) \\
\hline Ectopic thymus & - & $1(10 \%)$ & - & - & - & - & - \\
\hline \multicolumn{8}{|l|}{ General Body System } \\
\hline None & - & - & - & - & - & - & - \\
\hline \multicolumn{8}{|l|}{ Genital System } \\
\hline Clitoral gland & $(10)$ & (10) & (0) & $(0)$ & (0) & (10) & $(10)$ \\
\hline Ovary & $(10)$ & (10) & $(0)$ & $(0)$ & (0) & (10) & $(10)$ \\
\hline Uterus & $(10)$ & $(10)$ & $(0)$ & $(0)$ & $(0)$ & $(10)$ & $(10)$ \\
\hline Decidual reaction & - & $1(10 \%)$ & - & - & - & - & - \\
\hline $\begin{array}{l}\text { Endometrium, } \\
\text { hyperplasia, cystic }\end{array}$ & $1(10 \%)$ & $2(20 \%)$ & - & - & - & - & - \\
\hline \multicolumn{8}{|l|}{ Hematopoietic System } \\
\hline Bone marrow & $(10)$ & $(10)$ & (10) & $(10)$ & $(10)$ & (10) & $(10)$ \\
\hline $\begin{array}{r}\text { Myeloid cell, } \\
\text { hyperplasia }\end{array}$ & - & - & $2(20 \%)$ & $9(90 \%)$ & $10(100 \%)$ & $10(100 \%)$ & $10(100 \%)$ \\
\hline Lymph node & (0) & $(0)$ & $(0)$ & $(0)$ & (1) & $(2)$ & $(10)$ \\
\hline Hyperplasia, lymphoid & - & - & - & - & $1(100 \%)$ & $1(50 \%)$ & - \\
\hline $\begin{array}{l}\text { Axillary, hyperplasia, } \\
\text { lymphoid }\end{array}$ & - & - & - & - & - & $1(50 \%)$ & $10(100 \%)$ \\
\hline Lymph node, mandibular & $(10)$ & $(10)$ & $(10)$ & $(10)$ & $(10)$ & $(10)$ & $(10)$ \\
\hline Hyperplasia, lymphoid & - & $1(10 \%)$ & $6(60 \%)$ & $6(60 \%)$ & $5(50 \%)$ & $6(60 \%)$ & $10(100 \%)$ \\
\hline Lymph node, mesenteric & $(10)$ & $(10)$ & $(10)$ & $(10)$ & $(10)$ & $(10)$ & $(10)$ \\
\hline Spleen & $(10)$ & $(10)$ & $(10)$ & $(10)$ & $(10)$ & $(10)$ & $(10)$ \\
\hline $\begin{array}{l}\text { Hematopoietic cell } \\
\text { proliferation }\end{array}$ & $4(40 \%)$ & $2(20 \%)$ & $9(90 \%)$ & $10(100 \%)$ & $10(100 \%)$ & $10(100 \%)$ & $10(100 \%)$ \\
\hline $\begin{array}{l}\text { Inflammation, } \\
\text { chronic active }\end{array}$ & $1(10 \%)$ & - & - & - & - & - & - \\
\hline Thymus & $(10)$ & $(10)$ & $(10)$ & $(10)$ & $(10)$ & $(10)$ & $(10)$ \\
\hline \multicolumn{8}{|l|}{ Integumentary System } \\
\hline Mammary gland & $(10)$ & $(10)$ & $(0)$ & $(0)$ & $(0)$ & $(10)$ & $(10)$ \\
\hline Skin & $(10)$ & $(10)$ & $(10)$ & $(10)$ & $(10)$ & (10) & $(10)$ \\
\hline
\end{tabular}




\begin{tabular}{|c|c|c|c|c|c|c|c|}
\hline & $\begin{array}{l}\text { Untreated } \\
\text { Control }\end{array}$ & $\begin{array}{l}\text { Vehicle } \\
\text { Control }\end{array}$ & $6.25 \%$ & $12.5 \%$ & $25 \%$ & $50 \%$ & $100 \%$ \\
\hline $\begin{array}{l}\text { Hair follicle, } \\
\text { site of application, } \\
\text { dilatation }\end{array}$ & - & - & - & - & - & - & $3(30 \%)$ \\
\hline $\begin{array}{l}\text { Hair follicle, } \\
\text { site of application, } \\
\text { hyperplasia }\end{array}$ & - & - & $3(30 \%)$ & $10(100 \%)$ & $10(100 \%)$ & $10(100 \%)$ & $10(100 \%)$ \\
\hline $\begin{array}{l}\text { Sebaceous gland, } \\
\text { site of application, } \\
\text { hyperplasia }\end{array}$ & $1(10 \%)$ & - & $4(40 \%)$ & $10(100 \%)$ & $10(100 \%)$ & $10(100 \%)$ & $10(100 \%)$ \\
\hline $\begin{array}{l}\text { Site of application, } \\
\text { inflammation, } \\
\text { chronic active }\end{array}$ & - & - & $10(100 \%)$ & $10(100 \%)$ & $10(100 \%)$ & $10(100 \%)$ & $10(100 \%)$ \\
\hline $\begin{array}{l}\text { Site of application, } \\
\text { dermis, fibrosis }\end{array}$ & - & - & $2(20 \%)$ & $10(100 \%)$ & $10(100 \%)$ & $10(100 \%)$ & $10(100 \%)$ \\
\hline $\begin{array}{l}\text { Site of application, } \\
\text { epidermis, } \\
\text { hyperkeratosis }\end{array}$ & - & - & $2(20 \%)$ & $10(100 \%)$ & $10(100 \%)$ & $10(100 \%)$ & $10(100 \%)$ \\
\hline $\begin{array}{l}\text { Site of application, } \\
\text { epidermis, hyperplasia }\end{array}$ & - & - & $10(100 \%)$ & $10(100 \%)$ & $10(100 \%)$ & $10(100 \%)$ & $10(100 \%)$ \\
\hline $\begin{array}{l}\text { Site of application, } \\
\text { epidermis, ulcer }\end{array}$ & - & - & $2(20 \%)$ & $6(60 \%)$ & $9(90 \%)$ & $10(100 \%)$ & $10(100 \%)$ \\
\hline \multicolumn{8}{|l|}{ Musculoskeletal System } \\
\hline Bone & $(10)$ & $(10)$ & $(0)$ & $(0)$ & $(0)$ & $(10)$ & $(10)$ \\
\hline \multicolumn{8}{|l|}{ Nervous System } \\
\hline Brain & $(10)$ & $(10)$ & $(0)$ & (0) & $(0)$ & $(10)$ & $(10)$ \\
\hline \multicolumn{8}{|l|}{ Respiratory System } \\
\hline Lung & $(10)$ & $(10)$ & $(0)$ & $(0)$ & (0) & $(10)$ & $(10)$ \\
\hline Nose & $(10)$ & $(10)$ & $(0)$ & $(0)$ & $(0)$ & (10) & $(10)$ \\
\hline Trachea & (10) & $(10)$ & $(0)$ & $(0)$ & $(0)$ & $(10)$ & $(10)$ \\
\hline \multicolumn{8}{|l|}{ Special Senses System } \\
\hline Eye & $(10)$ & $(10)$ & $(0)$ & $(0)$ & $(0)$ & $(10)$ & $(10)$ \\
\hline Harderian gland & $(10)$ & $(10)$ & $(0)$ & $(0)$ & $(0)$ & $(10)$ & $(10)$ \\
\hline \multicolumn{8}{|l|}{ Urinary System } \\
\hline Kidney & $(10)$ & $(10)$ & $(0)$ & $(0)$ & $(0)$ & $(10)$ & $(10)$ \\
\hline $\begin{array}{l}\text { Inflammation, } \\
\text { chronic active }\end{array}$ & - & - & - & - & - & - & $2(20 \%)$ \\
\hline Nephropathy & - & - & - & - & - & $1(10 \%)$ & - \\
\hline Urinary bladder & (10) & (10) & $(0)$ & $(0)$ & $(0)$ & (10) & (10) \\
\hline
\end{tabular}

aNumber of animals examined microscopically at the site and the number of animals with lesion. 


\section{Appendix B. Hematology Results}

\section{Tables}

Table B-1. Hematology Data for Rats in the Three-month Dermal Study of Cedarwood

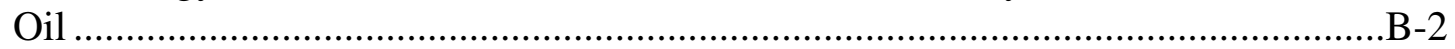

Table B-2. Hematology Data for Mice in the Three-month Dermal Study of Cedarwood

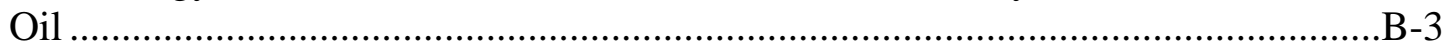




\section{Cedarwood Oil, NTP TOX 86}

Table B-1. Hematology Data for Rats in the Three-month Dermal Study of Cedarwood Oil ${ }^{\mathrm{a}}$

\begin{tabular}{|c|c|c|c|c|c|c|c|}
\hline & $\begin{array}{l}\text { Untreated } \\
\text { Control }\end{array}$ & $\begin{array}{l}\text { Vehicle } \\
\text { Control }\end{array}$ & $6.25 \%$ & $12.5 \%$ & $25 \%$ & $50 \%$ & $100 \%$ \\
\hline \multicolumn{8}{|l|}{ Male } \\
\hline $\mathbf{n}$ & 10 & 9 & 10 & 9 & 10 & 10 & 8 \\
\hline Hematocrit (\%) & $50.4 \pm 0.6$ & $49.2 \pm 0.6$ & $50.2 \pm 0.4$ & $48.8 \pm 0.8$ & $49.1 \pm 0.6$ & $48.5 \pm 0.3$ & $49.0 \pm 0.6$ \\
\hline Hemoglobin (g/dL) & $15.9 \pm 0.2$ & $15.6 \pm 0.2$ & $15.8 \pm 0.1$ & $15.4 \pm 0.2$ & $15.6 \pm 0.2$ & $15.4 \pm 0.1$ & $15.5 \pm 0.1$ \\
\hline Erythrocytes $\left(10^{6} / \mu \mathrm{L}\right)$ & $9.31 \pm 0.12$ & $9.12 \pm 0.11$ & $9.25 \pm 0.07$ & $9.08 \pm 0.14$ & $9.14 \pm 0.11$ & $9.04 \pm 0.05$ & $9.03 \pm 0.10 \dagger$ \\
\hline $\begin{array}{l}\text { Reticulocytes } \\
\left(10^{3} / \mu \mathrm{L}\right)\end{array}$ & $223.8 \pm 6.4$ & $237.7 \pm 8.0$ & $229.5 \pm 8.6$ & $234.7 \pm 10.3$ & $202.1 \pm 8.8^{*}$ & $203.8 \pm 8.6^{*}$ & $188.4 \pm 10.8 \dagger$ \\
\hline $\begin{array}{l}\text { Mean cell volume } \\
\text { (fL) }\end{array}$ & $54.1 \pm 0.2$ & $54.0 \pm 0.2$ & $54.2 \pm 0.2$ & $53.8 \pm 0.1$ & $53.7 \pm 0.2$ & $53.7 \pm 0.2$ & $54.3 \pm 0.1$ \\
\hline $\begin{array}{l}\text { Mean cell } \\
\text { hemoglobin (pg) }\end{array}$ & $17.1 \pm 0.1$ & $17.1 \pm 0.1$ & $17.1 \pm 0.1$ & $17.0 \pm 0.1$ & $17.0 \pm 0.1$ & $17.0 \pm 0.1$ & $17.2 \pm 0.1$ \\
\hline $\begin{array}{l}\text { Mean cell } \\
\text { hemoglobin } \\
\text { concentration } \\
\text { (g/dL) }\end{array}$ & $31.5 \pm 0.2$ & $31.7 \pm 0.1$ & $31.5 \pm 0.1$ & $31.6 \pm 0.1$ & $31.7 \pm 0.1$ & $31.6 \pm 0.1$ & $31.6 \pm 0.1$ \\
\hline Platelets $\left(10^{3} / \mu \mathrm{L}\right)$ & $545 \pm 16$ & $579 \pm 13$ & $577 \pm 20$ & $552 \pm 50$ & $559 \pm 42$ & $578 \pm 18$ & $632 \pm 18 \dagger \dagger$ \\
\hline Leukocytes $\left(10^{3} / \mu \mathrm{L}\right)$ & $8.16 \pm 0.36$ & $8.98 \pm 0.50$ & $8.87 \pm 0.38$ & $9.35 \pm 0.42$ & $8.89 \pm 0.23$ & $9.62 \pm 0.28$ & $10.60 \pm 0.17 \dagger \dagger$ \\
\hline $\begin{array}{l}\text { Segmented } \\
\text { neutrophils } \\
\left(10^{3} / \mu \mathrm{L}\right)\end{array}$ & $1.07 \pm 0.05$ & $1.23 \pm 0.06$ & $1.43 \pm 0.09$ & $1.33 \pm 0.08$ & $1.35 \pm 0.10$ & $1.70 \pm 0.13^{*}$ & $3.28 \pm 0.21 \dagger \dagger$ \\
\hline $\begin{array}{l}\text { Lymphocytes } \\
\qquad\left(10^{3} / \mu \mathrm{L}\right)\end{array}$ & $6.73 \pm 0.32$ & $7.41 \pm 0.48$ & $7.05 \pm 0.33$ & $7.62 \pm 0.42$ & $7.17 \pm 0.25$ & $7.54 \pm 0.33$ & $6.81 \pm 0.26$ \\
\hline Monocytes $\left(10^{3} / \mu \mathrm{L}\right)$ & $0.22 \pm 0.02$ & $0.21 \pm 0.02$ & $0.25 \pm 0.02$ & $0.24 \pm 0.03$ & $0.22 \pm 0.01$ & $0.22 \pm 0.01$ & $0.35 \pm 0.02 \dagger \dagger$ \\
\hline Basophils $\left(10^{3} / \mu \mathrm{L}\right)$ & $0.044 \pm 0.005$ & $0.068 \pm 0.010$ & $0.048 \pm 0.004$ & $0.064 \pm 0.005$ & $0.059 \pm 0.003$ & $0.060 \pm 0.006$ & $0.055 \pm 0.006$ \\
\hline Eosinophils $\left(10^{3} / \mu \mathrm{L}\right)$ & $0.09 \pm 0.01$ & $0.06 \pm 0.01$ & $0.09 \pm 0.01^{*}$ & $0.08 \pm 0.01$ & $0.08 \pm 0.01$ & $0.10 \pm 0.02$ & $0.11 \pm 0.01$ \\
\hline \multicolumn{8}{|l|}{ Female } \\
\hline $\mathbf{n}$ & 10 & 8 & 9 & 9 & 10 & 7 & 9 \\
\hline Hematocrit (\%) & $49.3 \pm 1.4$ & $47.5 \pm 0.3$ & $48.4 \pm 0.9$ & $47.8 \pm 0.9$ & $47.1 \pm 0.5$ & $48.9 \pm 1.1$ & $46.5 \pm 0.6 \dagger$ \\
\hline Hemoglobin (g/dL) & $16.1 \pm 0.4$ & $15.6 \pm 0.1$ & $15.8 \pm 0.2$ & $15.7 \pm 0.2$ & $15.6 \pm 0.1$ & $15.9 \pm 0.3$ & $15.2 \pm 0.2 \dagger$ \\
\hline Erythrocytes $\left(10^{6} / \mu \mathrm{L}\right)$ & $8.72 \pm 0.20$ & $8.42 \pm 0.07$ & $8.50 \pm 0.11$ & $8.50 \pm 0.12$ & $8.37 \pm 0.07$ & $8.62 \pm 0.16$ & $8.34 \pm 0.09$ \\
\hline $\begin{array}{l}\text { Reticulocytes } \\
\left(10^{3} / \mu \mathrm{L}\right)\end{array}$ & $210.4 \pm 7.7$ & $202.4 \pm 9.8$ & $222.9 \pm 15.2$ & $200.9 \pm 9.4$ & $205.5 \pm 7.2$ & $187.1 \pm 10.3$ & $191.2 \pm 4.5$ \\
\hline $\begin{array}{l}\text { Mean cell volume } \\
\text { (fL) }\end{array}$ & $56.5 \pm 0.4$ & $56.5 \pm 0.4$ & $56.9 \pm 0.3$ & $56.2 \pm 0.4$ & $56.2 \pm 0.3$ & $56.7 \pm 0.4$ & $55.9 \pm 0.2$ \\
\hline $\begin{array}{l}\text { Mean cell } \\
\text { hemoglobin (pg) }\end{array}$ & $18.5 \pm 0.1$ & $18.5 \pm 0.1$ & $18.6 \pm 0.1$ & $18.4 \pm 0.1$ & $18.6 \pm 0.1$ & $18.4 \pm 0.1$ & $18.3 \pm 0.1 \dagger$ \\
\hline $\begin{array}{l}\text { Mean cell } \\
\text { hemoglobin } \\
\text { concentration } \\
(\mathrm{g} / \mathrm{dL})\end{array}$ & $32.7 \pm 0.2$ & $32.8 \pm 0.2$ & $32.6 \pm 0.2$ & $32.8 \pm 0.2$ & $33.1 \pm 0.2$ & $32.6 \pm 0.2$ & $32.7 \pm 0.2$ \\
\hline Platelets $\left(10^{3} / \mu \mathrm{L}\right)$ & $501 \pm 47$ & $608 \pm 30$ & $473 \pm 57$ & $464 \pm 40 *$ & $504 \pm 38$ & $588 \pm 30$ & $537 \pm 56$ \\
\hline Leukocytes $\left(10^{3} / \mu \mathrm{L}\right)$ & $6.60 \pm 0.37$ & $6.85 \pm 0.57$ & $6.96 \pm 0.19$ & $7.04 \pm 0.38$ & $6.70 \pm 0.40$ & $8.89 \pm 0.33^{* *}$ & $9.47 \pm 0.35 \dagger \dagger$ \\
\hline
\end{tabular}




\section{Cedarwood Oil, NTP TOX 86}

\begin{tabular}{lccccccc}
\hline & $\begin{array}{c}\text { Untreated } \\
\text { Control }\end{array}$ & $\begin{array}{c}\text { Vehicle } \\
\text { Control }\end{array}$ & $\mathbf{6 . 2 5 \%}$ & $\mathbf{1 2 . 5 \%}$ & $\mathbf{2 5 \%}$ & $\mathbf{5 0 \%}$ & $\mathbf{1 0 0 \%}$ \\
\hline $\begin{array}{l}\text { Segmented } \\
\text { neutrophils } \\
\left(10^{3} / \mu \mathrm{L}\right)\end{array}$ & $1.02 \pm 0.11$ & $1.15 \pm 0.16$ & $0.97 \pm 0.07$ & $1.22 \pm 0.21$ & $1.18 \pm 0.08$ & $1.50 \pm 0.09 *$ & $2.38 \pm 0.15 \dagger \dagger$ \\
$\begin{array}{l}\text { Lymphocytes } \\
\left(10^{3} / \mu \mathrm{L}\right)\end{array}$ & $5.28 \pm 0.31$ & $5.39 \pm 0.45$ & $5.68 \pm 0.21$ & $5.49 \pm 0.28$ & $5.24 \pm 0.35$ & $6.97 \pm 0.30 *$ & $6.65 \pm 0.29 \dagger \dagger$ \\
$\begin{array}{l}\text { Monocytes }\left(10^{3} / \mu \mathrm{L}\right) \\
\text { Basophils }\left(10^{3} / \mu \mathrm{L}\right)\end{array}$ & $0.18 \pm 0.01$ & $0.20 \pm 0.03$ & $0.19 \pm 0.01$ & $0.19 \pm 0.02$ & $0.16 \pm 0.02$ & $0.25 \pm 0.01$ & $0.27 \pm 0.03 \dagger$ \\
Eosinophils $\left(10^{3} / \mu \mathrm{L}\right)$ & $0.07 \pm 0.01$ & $0.07 \pm 0.01$ & $0.08 \pm 0.02$ & $0.10 \pm 0.02$ & $0.09 \pm 0.01$ & $0.10 \pm 0.02$ & $0.12 \pm 0.01 \dagger$ \\
\hline
\end{tabular}

*Significantly different $(\mathrm{P} \leq 0.05)$ from the vehicle control group by Dunn’s or Shirley’s test.

$* * \mathrm{P} \leq 0.01$

$\dagger$ Significantly different $(\mathrm{P} \leq 0.05)$ from the untreated control group by Wilcoxon's rank sum test.

$\dagger \dagger \mathrm{P} \leq 0.01$.

${ }^{\text {a }}$ Data are presented as mean \pm standard error. Statistical tests were performed on unrounded data.

Table B-2. Hematology Data for Mice in the Three-month Dermal Study of Cedarwood Oil ${ }^{\text {a }}$

\begin{tabular}{|c|c|c|c|c|c|}
\hline & $\begin{array}{l}\text { Vehicle } \\
\text { Control }\end{array}$ & $6.25 \%$ & $12.5 \%$ & $25 \%$ & $50 \%$ \\
\hline \multicolumn{6}{|l|}{ Male } \\
\hline $\mathbf{n}$ & 9 & 10 & 9 & 10 & 9 \\
\hline Hematocrit (\%) & $46.9 \pm 0.8$ & $45.4 \pm 0.6$ & $44.7 \pm 0.6^{*}$ & $44.0 \pm 0.7^{* *}$ & $41.2 \pm 0.7^{* *}$ \\
\hline Hemoglobin (g/dL) & $15.9 \pm 0.3$ & $15.5 \pm 0.2$ & $15.1 \pm 0.2^{*}$ & $14.8 \pm 0.2^{* *}$ & $13.9 \pm 0.2^{* *}$ \\
\hline Erythrocytes $\left(10^{6} / \mu \mathrm{L}\right)$ & $10.30 \pm 0.20$ & $9.95 \pm 0.13$ & $9.77 \pm 0.12 *$ & $9.61 \pm 0.12^{* *}$ & $9.06 \pm 0.16^{* *}$ \\
\hline Reticulocytes $\left(10^{3} / \mu \mathrm{L}\right)$ & $328.3 \pm 10.9$ & $309.3 \pm 11.4$ & $321.2 \pm 9.8$ & $319.4 \pm 9.6$ & $330.7 \pm 24.6$ \\
\hline Mean cell volume (fL) & $45.5 \pm 0.1$ & $45.6 \pm 0.1$ & $45.7 \pm 0.2$ & $45.7 \pm 0.2$ & $45.5 \pm 0.2$ \\
\hline Mean cell hemoglobin (pg) & $15.5 \pm 0.1$ & $15.6 \pm 0.1$ & $15.4 \pm 0.1$ & $15.4 \pm 0.1$ & $15.4 \pm 0.1$ \\
\hline $\begin{array}{l}\text { Mean cell hemoglobin } \\
\text { concentration (g/dL) }\end{array}$ & $34.0 \pm 0.2$ & $34.2 \pm 0.1$ & $33.8 \pm 0.2$ & $33.7 \pm 0.2$ & $33.7 \pm 0.2$ \\
\hline Platelets $\left(10^{3} / \mu \mathrm{L}\right)$ & $938 \pm 49$ & $992 \pm 47$ & $1,061 \pm 54$ & $1,136 \pm 37^{* *}$ & $1,111 \pm 44^{*}$ \\
\hline Leukocytes $\left(10^{3} / \mu \mathrm{L}\right)$ & $5.14 \pm 0.13$ & $5.55 \pm 0.29$ & $5.82 \pm 0.35$ & $5.83 \pm 0.35$ & $6.07 \pm 0.66$ \\
\hline $\begin{array}{l}\text { Segmented neutrophils } \\
\left(10^{3} / \mu \mathrm{L}\right)\end{array}$ & $0.77 \pm 0.07$ & $0.85 \pm 0.16$ & $0.89 \pm 0.08$ & $0.85 \pm 0.85$ & $1.99 \pm 0.43^{* *}$ \\
\hline Lymphocytes $\left(10^{3} / \mu \mathrm{L}\right)$ & $4.15 \pm 0.11$ & $4.21 \pm 0.22$ & $4.42 \pm 0.21$ & $4.54 \pm 0.28$ & $3.73 \pm 0.27$ \\
\hline Monocytes $\left(10^{3} / \mu \mathrm{L}\right)$ & $0.10 \pm 0.01$ & $0.13 \pm 0.01$ & $0.11 \pm 0.01$ & $0.11 \pm 0.02$ & $0.10 \pm 0.02$ \\
\hline Basophils $\left(10^{3} / \mu \mathrm{L}\right)$ & $0.014 \pm 0.005$ & $0.017 \pm 0.003$ & $0.017 \pm 0.004$ & $0.012 \pm 0.002$ & $0.016 \pm 0.003$ \\
\hline Eosinophils $\left(10^{3} / \mu \mathrm{L}\right)$ & $0.11 \pm 0.02$ & $0.35 \pm 0.04^{* *}$ & $0.39 \pm 0.09 * *$ & $0.31 \pm 0.06^{*}$ & $0.23 \pm 0.03$ \\
\hline \multicolumn{6}{|l|}{ Female } \\
\hline $\mathbf{n}$ & 10 & 10 & 10 & 10 & 8 \\
\hline Hematocrit (\%) & $46.9 \pm 0.7$ & $45.8 \pm 0.6$ & $45.2 \pm 0.7$ & $44.0 \pm 0.6^{* *}$ & $40.9 \pm 0.4^{* *}$ \\
\hline Hemoglobin (g/dL) & $16.4 \pm 0.2$ & $16.0 \pm 0.2$ & $15.7 \pm 0.2^{*}$ & $15.2 \pm 0.2^{* *}$ & $14.1 \pm 0.1^{* *}$ \\
\hline Erythrocytes $\left(10^{6} / \mu \mathrm{L}\right)$ & $10.22 \pm 0.14$ & $9.99 \pm 0.11$ & $9.93 \pm 0.15$ & $9.70 \pm 0.14^{* *}$ & $8.92 \pm 0.08^{* *}$ \\
\hline
\end{tabular}




\section{Cedarwood Oil, NTP TOX 86}

\begin{tabular}{lccccc}
\hline & $\begin{array}{c}\text { Vehicle } \\
\text { Control }\end{array}$ & $\mathbf{6 . 2 5 \%}$ & $\mathbf{1 2 . 5 \%}$ & $\mathbf{2 5 \%}$ & $\mathbf{5 0 \%}$ \\
\hline Reticulocytes $\left(10^{3} / \mu \mathrm{L}\right)$ & $343.6 \pm 15.3$ & $284.2 \pm 8.8^{*}$ & $343.3 \pm 21.5$ & $307.4 \pm 15.0$ & $311.7 \pm 27.2$ \\
Mean cell volume (fL) & $45.9 \pm 0.1$ & $45.9 \pm 0.2$ & $45.6 \pm 0.1$ & $45.4 \pm 0.1^{*}$ & $45.9 \pm 0.2$ \\
Mean cell hemoglobin (pg) & $16.0 \pm 0.0$ & $16.0 \pm 0.1$ & $15.8 \pm 0.1^{*}$ & $15.7 \pm 0.1^{* *}$ & $15.9 \pm 0.1^{*}$ \\
Mean cell hemoglobin & $34.9 \pm 0.1$ & $34.9 \pm 0.1$ & $34.7 \pm 0.2$ & $34.5 \pm 0.1$ & $34.5 \pm 0.2$ \\
$\quad$ concentration $(\mathrm{g} / \mathrm{dL})$ & & & & & \\
Platelets $\left(10^{3} / \mu \mathrm{L}\right)$ & $685 \pm 47$ & $764 \pm 42$ & $887 \pm 64^{*}$ & $960 \pm 57^{* *}$ & $1,058 \pm 43^{* *}$ \\
Leukocytes $\left(10^{3} / \mu \mathrm{L}\right)$ & $5.07 \pm 0.30$ & $4.66 \pm 0.18$ & $5.56 \pm 0.36$ & $6.23 \pm 0.30^{*}$ & $6.98 \pm 0.21^{* *}$ \\
Segmented neutrophils & $0.65 \pm 0.07$ & $0.52 \pm 0.03$ & $0.80 \pm 0.12$ & $1.27 \pm 0.14^{*}$ & $1.65 \pm 0.18^{* *}$ \\
$\quad\left(10^{3} / \mu \mathrm{L}\right)$ & & & & \\
Lymphocytes $\left(10^{3} / \mu \mathrm{L}\right)$ & $4.15 \pm 0.27$ & $3.87 \pm 0.17$ & $4.39 \pm 0.30$ & $4.58 \pm 0.23$ & $4.90 \pm 0.23^{*}$ \\
Monocytes $\left(10^{3} / \mu \mathrm{L}\right)$ & $0.11 \pm 0.02$ & $0.10 \pm 0.01$ & $0.13 \pm 0.01$ & $0.11 \pm 0.02$ & $0.12 \pm 0.01$ \\
Basophils $\left(10^{3} / \mu \mathrm{L}\right)$ & $0.011 \pm 0.005$ & $0.009 \pm 0.003$ & $0.022 \pm 0.007$ & $0.013 \pm 0.004$ & $0.036 \pm 0.004^{* *}$ \\
Eosinophils $\left(10^{3} / \mu \mathrm{L}\right)$ & $0.15 \pm 0.02$ & $0.17 \pm 0.05$ & $0.22 \pm 0.04$ & $0.26 \pm 0.06$ & $0.28 \pm 0.03$ \\
\hline
\end{tabular}

*Significantly different $(\mathrm{P} \leq 0.05)$ from the vehicle control group by Dunn’s or Shirley’s test.

$* * \mathrm{P} \leq 0.01$.

aData are presented as mean \pm standard error. Statistical tests were performed on unrounded data. 


\section{Appendix C. Organ Weights and Organ-Weight-to-Body- Weight Ratios}

\section{Tables}

Table C-1. Organ Weights and Organ-Weight-to-Body-Weight Ratios for Rats in the Three-month Dermal Study of Cedarwood Oil

Table C-2. Organ Weights and Organ-Weight-to-Body-Weight Ratios for Mice in the Three-month Dermal Study of Cedarwood Oil .C-3 
Table C-1. Organ Weights and Organ-Weight-to-Body-Weight Ratios for Rats in the Three-month Dermal Study of Cedarwood Oil ${ }^{\mathrm{a}}$

\begin{tabular}{|c|c|c|c|c|c|c|c|}
\hline & $\begin{array}{c}\text { Untreated } \\
\text { Control }\end{array}$ & $\begin{array}{l}\text { Vehicle } \\
\text { Control }\end{array}$ & $6.25 \%$ & $12.5 \%$ & $25 \%$ & $50 \%$ & $100 \%$ \\
\hline $\mathbf{n}$ & 10 & 10 & 10 & 10 & 10 & 10 & 8 \\
\hline \multicolumn{8}{|l|}{ Male } \\
\hline Necropsy body wt & $323 \pm 4$ & $329 \pm 4$ & $318 \pm 5$ & $316 \pm 6$ & $308 \pm 10$ & $301 \pm 8^{*}$ & $279 \pm 7 \dagger \dagger$ \\
\hline \multicolumn{8}{|l|}{ Heart } \\
\hline Absolute & $0.91 \pm 0.01$ & $0.91 \pm 0.01$ & $0.92 \pm 0.02$ & $0.91 \pm 0.02$ & $0.88 \pm 0.03$ & $0.90 \pm 0.02$ & $0.87 \pm 0.02$ \\
\hline Relative & $2.83 \pm 0.02$ & $2.77 \pm 0.03$ & $2.89 \pm 0.05$ & $2.90 \pm 0.04$ & $2.87 \pm 0.03$ & $2.99 \pm 0.04^{* *}$ & $3.12 \pm 0.05 \dagger \dagger$ \\
\hline \multicolumn{8}{|l|}{ R. Kidney } \\
\hline Absolute & $1.09 \pm 0.02$ & $1.15 \pm 0.02 \dagger$ & $1.08 \pm 0.03$ & $1.10 \pm 0.02$ & $1.12 \pm 0.04$ & $1.19 \pm 0.03$ & $1.33 \pm 0.05 \dagger \dagger$ \\
\hline Relative & $3.37 \pm 0.05$ & $3.51 \pm 0.04 \dagger$ & $3.40 \pm 0.04$ & $3.50 \pm 0.07$ & $3.63 \pm 0.06$ & $3.96 \pm 0.08^{* *}$ & $4.77 \pm 0.11 \dagger \dagger$ \\
\hline \multicolumn{8}{|l|}{ Liver } \\
\hline Absolute & $12.42 \pm 0.37$ & $12.75 \pm 0.26$ & $12.91 \pm 0.38$ & $12.47 \pm 0.31$ & $12.60 \pm 0.49$ & $13.07 \pm 0.37$ & $13.43 \pm 0.42$ \\
\hline Relative & $38.55 \pm 1.21$ & $38.79 \pm 0.58$ & $40.58 \pm 0.97$ & $39.52 \pm 0.75$ & $40.89 \pm 0.86$ & $43.49 \pm 0.84^{* *}$ & $48.18 \pm 1.31 \dagger \dagger$ \\
\hline \multicolumn{8}{|c|}{ 烈 } \\
\hline Absolute & $2.02 \pm 0.11$ & $1.98 \pm 0.09$ & $1.94 \pm 0.11$ & $1.93 \pm 0.05$ & $1.99 \pm 0.11$ & $0.95 \pm 0.06$ & $2.04 \pm 0.10$ \\
\hline Relative & $6.26 \pm 0.32$ & $6.02 \pm 0.23$ & $6.10 \pm 0.30$ & $6.12 \pm 0.15$ & $6.42 \pm 0.20$ & $6.51 \pm 1.22$ & $7.30 \pm 0.31 \dagger$ \\
\hline \multicolumn{8}{|l|}{ R. Testis } \\
\hline Absolute & $1.398 \pm 0.018$ & $1.384 \pm 0.014$ & $1.376 \pm 0.024$ & $1.314 \pm 0.086$ & $1.373 \pm 0.025$ & $1.389 \pm 0.025$ & $1.341 \pm 0.020$ \\
\hline Relative & $4.335 \pm 0.058$ & $4.216 \pm 0.056$ & $4.339 \pm 0.107$ & $4.144 \pm 0.258$ & $4.477 \pm 0.094$ & $4.627 \pm 0.064^{*}$ & $4.819 \pm 0.106 \dagger \dagger$ \\
\hline \multicolumn{8}{|c|}{ 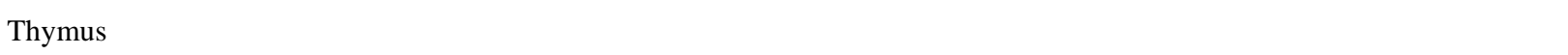 } \\
\hline Absolute & $0.282 \pm 0.013$ & $0.282 \pm 0.006$ & $0.277 \pm 0.008$ & $0.280 \pm 0.010$ & $0.245 \pm 0.011^{*}$ & $0.271 \pm 0.014$ & $0.223 \pm 0.016 \dagger$ \\
\hline Relative & $0.875 \pm 0.044$ & $0.857 \pm 0.014$ & $0.870 \pm 0.023$ & $0.887 \pm 0.033$ & $0.798 \pm 0.032$ & $0.904 \pm 0.049$ & $0.797 \pm 0.051$ \\
\hline \multicolumn{8}{|c|}{ C } \\
\hline Necropsy body wt & $200 \pm 4$ & $197 \pm 2$ & $199 \pm 4$ & $194 \pm 5$ & $193 \pm 4$ & $182 \pm 4^{*}$ & $179 \pm 3 \dagger \dagger$ \\
\hline \multicolumn{8}{|l|}{ Heart } \\
\hline Absolute & $0.66 \pm 0.02$ & $0.64 \pm 0.01$ & $0.66 \pm 0.02$ & $0.65 \pm 0.02$ & $0.66 \pm 0.02$ & $0.63 \pm 0.02$ & $0.65 \pm 0.02$ \\
\hline Relative & $3.33 \pm 0.08$ & $3.27 \pm 0.05$ & $3.31 \pm 0.05$ & $3.35 \pm 0.07$ & $3.41 \pm 0.05$ & $3.46 \pm 0.08$ & $3.64 \pm 0.09$ \\
\hline \multicolumn{8}{|l|}{ R. Kidney } \\
\hline Absolute & $0.72 \pm 0.01$ & $0.71 \pm 0.02$ & $0.73 \pm 0.02$ & $0.71 \pm 0.02$ & $0.74 \pm 0.02$ & $0.70 \pm 0.02$ & $0.75 \pm 0.01$ \\
\hline Relative & $3.59 \pm 0.07$ & $3.59 \pm 0.05$ & $3.65 \pm 0.04$ & $3.63 \pm 0.05$ & $3.85 \pm 0.06^{* *}$ & $3.86 \pm 0.07 * *$ & $4.17 \pm 0.09 \dagger \dagger$ \\
\hline \multicolumn{8}{|l|}{ Liver } \\
\hline Absolute & $6.97 \pm 0.18$ & $7.02 \pm 0.18$ & $6.93 \pm 0.23$ & $7.10 \pm 0.19$ & $7.14 \pm 0.18$ & $6.80 \pm 0.21$ & $7.58 \pm 0.13 \dagger$ \\
\hline Relative & $34.94 \pm 0.60$ & $35.62 \pm 0.79$ & $34.74 \pm 0.55$ & $36.60 \pm 0.62$ & $36.98 \pm 0.56$ & $37.28 \pm 0.56$ & $42.30 \pm 0.42 \dagger \dagger$ \\
\hline \multicolumn{8}{|l|}{ Lung } \\
\hline Absolute & $1.68 \pm 0.14$ & $1.41 \pm 0.07$ & $1.56 \pm 0.13$ & $1.55 \pm 0.08$ & $1.53 \pm 0.11$ & $1.53 \pm 0.12$ & $1.45 \pm 0.08$ \\
\hline Relative & $8.44 \pm 0.66$ & $7.15 \pm 0.33$ & $7.82 \pm 0.58$ & $8.07 \pm 0.50$ & $7.89 \pm 0.51$ & $8.39 \pm 0.63$ & $8.06 \pm 0.38$ \\
\hline Thymus & & & & & & & \\
\hline
\end{tabular}




\begin{tabular}{lccccccc}
\hline & $\begin{array}{c}\text { Untreated } \\
\text { Control }\end{array}$ & $\begin{array}{c}\text { Vehicle } \\
\text { Control }\end{array}$ & $\mathbf{6 . 2 5 \%}$ & $\mathbf{1 2 . 5 \%}$ & $\mathbf{2 5 \%}$ & $\mathbf{5 0 \%}$ & $\mathbf{1 0 0 \%}$ \\
\hline Absolute & $0.279 \pm 0.016$ & $0.240 \pm 0.006 \dagger$ & $0.263 \pm 0.012$ & $0.245 \pm 0.013$ & $0.244 \pm 0.008$ & $0.225 \pm 0.009$ & $0.213 \pm 0.009 \dagger \dagger$ \\
Relative & $1.395 \pm 0.071$ & $1.220 \pm 0.030 \dagger 1.320 \pm 0.055$ & $1.265 \pm 0.064$ & $1.262 \pm 0.036$ & $1.236 \pm 0.046$ & $1.189 \pm 0.055 \dagger \dagger$ \\
\hline
\end{tabular}

*Significantly different $(\mathrm{P} \leq 0.05)$ from the vehicle control group by Williams' or Dunnett’s test.

$* * \mathrm{P} \leq 0.01$.

†Significantly different $(\mathrm{P} \leq 0.05)$ from the untreated control group by $t$-test.

$\dagger+\mathrm{P} \leq 0.01$.

${ }^{a}$ Organ weights (absolute weights) and body weights are given in grams; organ-weight-to-body-weight ratios (relative weights) are given as mg organ weight/g body weight (mean \pm standard error).

Table C-2. Organ Weights and Organ-Weight-to-Body-Weight Ratios for Mice in the Three-month Dermal Study of Cedarwood Oil ${ }^{\text {a }}$

\begin{tabular}{|c|c|c|c|c|c|}
\hline & $\begin{array}{l}\text { Vehicle } \\
\text { Control }\end{array}$ & $6.25 \%$ & $12.5 \%$ & $25 \%$ & $50 \%$ \\
\hline \multicolumn{6}{|l|}{ Male } \\
\hline $\mathbf{n}$ & 10 & 10 & 9 & 10 & 9 \\
\hline Necropsy body wt & $36.9 \pm 0.8$ & $36.0 \pm 0.6$ & $35.1 \pm 1.1$ & $33.1 \pm 0.9 * *$ & $31.9 \pm 0.7^{* *}$ \\
\hline \multicolumn{6}{|l|}{ Heart } \\
\hline Absolute & $0.19 \pm 0.01$ & $0.22 \pm 0.01$ & $0.23 \pm 0.01 *$ & $0.23 \pm 0.01^{* *}$ & $0.25 \pm 0.02 * *$ \\
\hline Relative & $5.15 \pm 0.26$ & $5.96 \pm 0.21$ & $6.60 \pm 0.31^{* *}$ & $7.07 \pm 0.33^{* *}$ & $7.80 \pm 0.52^{* *}$ \\
\hline \multicolumn{6}{|l|}{ R. Kidney } \\
\hline Absolute & $0.29 \pm 0.01$ & $0.29 \pm 0.01$ & $0.30 \pm 0.01$ & $0.28 \pm 0.01$ & $0.29 \pm 0.01$ \\
\hline Relative & $7.94 \pm 0.12$ & $8.16 \pm 0.22$ & $8.51 \pm 0.21$ & $8.35 \pm 0.26$ & $9.03 \pm 0.14^{* *}$ \\
\hline \multicolumn{6}{|l|}{ Liver } \\
\hline Absolute & $1.66 \pm 0.04$ & $1.76 \pm 0.04$ & $1.81 \pm 0.05$ & $1.77 \pm 0.06$ & $1.98 \pm 0.04^{* *}$ \\
\hline Relative & $45.06 \pm 0.58$ & $48.85 \pm 1.18^{* *}$ & $51.51 \pm 0.57^{* *}$ & $53.44 \pm 1.06^{* *}$ & $62.12 \pm 1.21^{* *}$ \\
\hline \multicolumn{6}{|l|}{ Lung } \\
\hline Absolute & $0.31 \pm 0.02$ & $0.29 \pm 0.01$ & $0.29 \pm 0.01$ & $0.28 \pm 0.01$ & $0.28 \pm 0.02$ \\
\hline Relative & $8.39 \pm 0.49$ & $7.93 \pm 0.37$ & $8.31 \pm 0.49$ & $8.37 \pm 0.24$ & $8.67 \pm 0.45$ \\
\hline \multicolumn{6}{|l|}{ R. Testis } \\
\hline Absolute & $0.118 \pm 0.003$ & $0.117 \pm 0.003$ & $0.116 \pm 0.004$ & $0.118 \pm 0.003$ & $0.114 \pm 0.004$ \\
\hline Relative & $3.188 \pm 0.054$ & $3.258 \pm 0.107$ & $3.319 \pm 0.094$ & $3.568 \pm 0.087^{* *}$ & $3.574 \pm 0.107^{* *}$ \\
\hline \multicolumn{6}{|l|}{ Thymus } \\
\hline Absolute & $0.048 \pm 0.004$ & $0.050 \pm 0.002$ & $0.044 \pm 0.003$ & $0.040 \pm 0.001^{*}$ & $0.038 \pm 0.002 *$ \\
\hline Relative & $1.306 \pm 0.077$ & $1.374 \pm 0.057$ & $1.232 \pm 0.063$ & $1.224 \pm 0.041$ & $1.205 \pm 0.073$ \\
\hline
\end{tabular}

\section{Female}

\begin{tabular}{lccccc}
$\mathbf{n}$ & 10 & 10 & 10 & 10 & 9 \\
\hline $\begin{array}{l}\text { Necropsy body wt } \\
\text { Heart }\end{array}$ & $34.7 \pm 1.1$ & $34.0 \pm 0.9$ & $30.5 \pm 0.7^{* *}$ & $28.1 \pm 0.6^{* *}$ & $30.2 \pm 0.4^{* *}$ \\
$\quad$ & & & & \\
$\quad$ Absolute & $0.18 \pm 0.01$ & $0.19 \pm 0.01$ & $0.20 \pm 0.01^{*}$ & $0.22 \pm 0.01^{* *}$ & $0.24 \pm 0.01^{* *}$
\end{tabular}




\section{Cedarwood Oil, NTP TOX 86}

\begin{tabular}{cccccc}
\hline & $\begin{array}{c}\text { Vehicle } \\
\text { Control }\end{array}$ & $\mathbf{6 . 2 5 \%}$ & $\mathbf{1 2 . 5 \%}$ & $\mathbf{2 5 \%}$ & $\mathbf{5 0 \%}$ \\
\hline $\begin{array}{c}\text { Relative } \\
\text { R. Kidney } \\
\text { Absolute }\end{array}$ & $5.17 \pm 0.17$ & $5.54 \pm 0.21$ & $6.70 \pm 0.37 * *$ & $7.70 \pm 0.26^{* *}$ & $8.02 \pm 0.31^{* *}$ \\
Relative & $0.19 \pm 0.01$ & $0.20 \pm 0.00$ & $0.20 \pm 0.00$ & $0.20 \pm 0.00$ & $0.24 \pm 0.01^{* *}$ \\
Liver & $5.58 \pm 0.18$ & $5.94 \pm 0.13$ & $6.67 \pm 0.18^{* *}$ & $7.07 \pm 0.15^{* *}$ & $7.86 \pm 0.16^{* *}$ \\
Absolute & $1.58 \pm 0.05$ & $1.65 \pm 0.02$ & $1.62 \pm 0.03$ & $1.60 \pm 0.04$ & $2.05 \pm 0.05^{* *}$ \\
Relative & $45.61 \pm 0.79$ & $48.75 \pm 0.79 *$ & $53.24 \pm 0.77^{* *}$ & $57.10 \pm 1.02^{* *}$ & $67.80 \pm 0.82^{* *}$ \\
Lung & & & & \\
Absolute & $0.30 \pm 0.01$ & $0.31 \pm 0.01$ & $0.29 \pm 0.02$ & $0.28 \pm 0.01$ & $0.27 \pm 0.02$ \\
Relative & $8.78 \pm 0.35$ & $9.05 \pm 0.27$ & $9.40 \pm 0.46$ & $10.09 \pm 0.37$ & $9.06 \pm 0.59$ \\
Thymus & & & & & \\
Absolute & $0.061 \pm 0.004$ & $0.068 \pm 0.004$ & $0.051 \pm 0.002^{*}$ & $0.051 \pm 0.003^{*}$ & $0.045 \pm 0.002^{* *}$ \\
Relative & $1.759 \pm 0.087$ & $1.990 \pm 0.096$ & $1.679 \pm 0.063$ & $1.802 \pm 0.076$ & $1.506 \pm 0.070$ \\
\hline
\end{tabular}

*Significantly different $(\mathrm{P} \leq 0.05)$ from the vehicle control group by Williams' test.

$* * \mathrm{P} \leq 0.01$.

${ }^{a}$ Organ weights (absolute weights) and body weights are given in grams; organ-weight-to-body-weight ratios (relative weights) are given as $\mathrm{mg}$ organ weight/g body weight (mean \pm standard error). 


\section{Appendix D. Reproductive Tissue Evaluations and Estrous Cycle Characterization}

\section{Tables}

Table D-1. Summary of Reproductive Tissue Evaluations for Male Rats in the Threemonth Dermal Study of Cedarwood Oil............................................................ D-2

Table D-2. Estrous Cycle Characterization for Female Rats in the Three-month Dermal

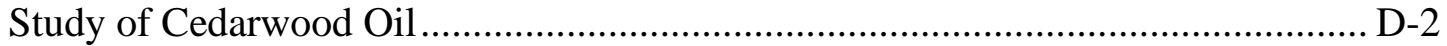

Table D-3. Results of Vaginal Cytology Study Using the Transition Matrix Approach for Female Rats in the Three-month Dermal Study of Cedarwood Oil ........................ D-3

Table D-4. Summary of Reproductive Tissue Evaluations for Male Mice in the Threemonth Dermal Study of Cedarwood Oil.............................................................. D-4

Table D-5. Estrous Cycle Characterization for Female Mice in the Three-month Dermal Study of Cedarwood Oil D-4

Table D-6. Results of Vaginal Cytology Study Using the Transition Matrix Approach for Female Mice in the Three-month Dermal Study of Cedarwood Oil D-5

\section{Figures}

Figure D-1. Vaginal Cytology Plots for Female Rats in the Three-month Dermal Study of Cedarwood Oil.... D-6

Figure D-2. Vaginal Cytology Plots for Female Mice in the Three-month Dermal Study of Cedarwood Oil 
Table D-1. Summary of Reproductive Tissue Evaluations for Male Rats in the Three-month Dermal Study of Cedarwood Oil ${ }^{\mathrm{a}}$

\begin{tabular}{lcccc}
\hline & $\begin{array}{c}\text { Vehicle } \\
\text { Control }\end{array}$ & $\mathbf{1 2 . 5 \%}$ & $\mathbf{2 5 \%}$ & $\mathbf{5 0 \%}$ \\
\hline $\mathbf{n}$ & 10 & 10 & 10 & 10 \\
\hline Weights (g) & & & & \\
$\quad$ Necropsy body wt & $329 \pm 4$ & $316 \pm 6$ & $308 \pm 10$ & $301 \pm 8^{*}$ \\
L. Cauda epididymis & $0.1545 \pm 0.0019$ & $0.1466 \pm 0.0037$ & $0.1495 \pm 0.0072$ & $0.1495 \pm 0.0079$ \\
L. Epididymis & $0.4592 \pm 0.0120$ & $0.4424 \pm 0.0115$ & $0.4502 \pm 0.0171$ & $0.4416 \pm 0.0138$ \\
L. Testis & $1.4565 \pm 0.0142$ & $1.4440 \pm 0.0070$ & $1.4260 \pm 0.0251$ & $1.4240 \pm 0.0257$ \\
Spermatid measurements & & & & \\
$\quad$ Spermatid heads (10\%/testis) & $179.50 \pm 4.85$ & $187.63 \pm 8.09$ & $186.13 \pm 10.08$ & $197.63 \pm 6.46$ \\
$\quad$ Spermatid heads (10\%/g testis) & $138.35 \pm 4.10$ & $146.15 \pm 6.60$ & $147.21 \pm 7.31$ & $156.29 \pm 4.67$ \\
Epididymal spermatozoal measurements & & & & \\
$\quad$ Sperm motility (\%) & $84.7 \pm 0.6$ & $84.7 \pm 0.7$ & $83.7 \pm 0.6$ & $84.2 \pm 0.8$ \\
Sperm (10\%/cauda epididymis) & $115.0 \pm 7.2$ & $116.4 \pm 7.7$ & $121.4 \pm 8.4$ & $107.2 \pm 9.9$ \\
$\quad$ Sperm (10\%/g cauda epididymis) & $748.5 \pm 51.7$ & $794.9 \pm 49.6$ & $811.5 \pm 36.4$ & $716.3 \pm 55.4$ \\
\hline
\end{tabular}

*Significantly different $(\mathrm{P} \leq 0.05)$ from the vehicle control group by Dunnett’s test.

aData are presented as mean \pm standard error. Differences from the vehicle control group are not significant by Dunnett's test (tissue weights) or Dunn's test (spermatid and epididymal spermatozoal measurements).

Table D-2. Estrous Cycle Characterization for Female Rats in the Three-month Dermal Study of Cedarwood Oil ${ }^{\mathrm{a}}$

\begin{tabular}{lcccc}
\hline & $\begin{array}{c}\text { Vehicle } \\
\text { Control }\end{array}$ & $\mathbf{1 2 . 5 \%}$ & $\mathbf{2 5 \%}$ & $\mathbf{5 0 \%}$ \\
\hline Number weighed at necropsy & 10 & 10 & 10 & 10 \\
$\quad$ Necropsy body wt (g) & $197 \pm 2$ & $193 \pm 4$ & $182 \pm 4^{* *}$ & $179 \pm 3^{* *}$ \\
Proportion of regular cycling females ${ }^{\mathrm{b}}$ & $10 / 10$ & $10 / 10$ & $10 / 10$ & $10 / 10$ \\
Estrous cycle length (days) & $5.0 \pm 0.0$ & $5.0 \pm 0.0$ & $5.1 \pm 0.1$ & $5.0 \pm 0.0$ \\
Estrous stages (\% of cycle) & & & & \\
Diestrus & 60.8 & 62.5 & 62.5 & 55.0 \\
Proestrus & 20.0 & 17.5 & 16.7 & 20.8 \\
Estrus & 19.2 & 19.2 & 19.2 & 22.5 \\
Metestrus & 0.0 & 0.0 & 0.0 & 0.0 \\
Uncertain diagnosis & 0.0 & 0.8 & 1.7 & 1.7 \\
\hline
\end{tabular}

**Significantly different $(\mathrm{P} \leq 0.01)$ from the vehicle control group by Williams' test.

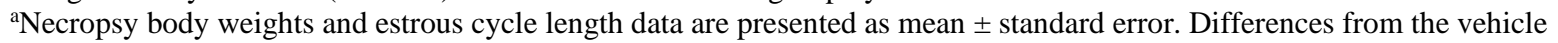
control group were not significant by Dunn's test (estrous cycle length). By multivariate analysis of variance, dosed females do not differ significantly from the vehicle control females in the relative length of time spent in the estrous stages. Tests for equality of transition probability matrices among all groups and between the vehicle control group and each dosed group indicated no significant differences in transition probabilities among the groups.

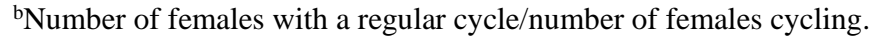


Table D-3. Results of Vaginal Cytology Study Using the Transition Matrix Approach for Female Rats in the Three-month Dermal Study of Cedarwood Oil

\begin{tabular}{|c|c|c|c|}
\hline Stage & Comparison & P Value & Trend $^{\mathbf{a}}$ \\
\hline Overall tests & Overall & 0.989 & \\
\hline Overall tests & $12.5 \%$ vs. vehicle controls & 0.953 & - \\
\hline Overall tests & $25 \%$ vs. vehicle controls & 0.683 & - \\
\hline Overall tests & $50 \%$ vs. vehicle controls & 0.975 & - \\
\hline Extended estrus & Overall & 0.918 & \\
\hline Extended estrus & $12.5 \%$ vs. vehicle controls & 0.604 & - \\
\hline Extended estrus & $25 \%$ vs. vehicle controls & 1 & - \\
\hline Extended estrus & $50 \%$ vs. vehicle controls & 0.604 & - \\
\hline Extended diestrus & Overall & 0.993 & \\
\hline Extended diestrus & $12.5 \%$ vs. vehicle controls & 1 & - \\
\hline Extended diestrus & $25 \%$ vs. vehicle controls & 0.683 & - \\
\hline Extended diestrus & $50 \%$ vs. vehicle controls & 0.996 & $\mathrm{~N}$ \\
\hline Extended metestrus & Overall & 1 & \\
\hline Extended metestrus & $12.5 \%$ vs. vehicle controls & 1 & - \\
\hline Extended metestrus & $25 \%$ vs. vehicle controls & 1 & - \\
\hline Extended metestrus & $50 \%$ vs. vehicle controls & 1 & - \\
\hline Extended proestrus & Overall & 1 & \\
\hline Extended proestrus & $12.5 \%$ vs. vehicle controls & 1 & - \\
\hline Extended proestrus & $25 \%$ vs. vehicle controls & 1 & - \\
\hline Extended proestrus & $50 \%$ vs. vehicle controls & 1 & - \\
\hline Skipped estrus & Overall & 1 & \\
\hline Skipped estrus & $12.5 \%$ vs. vehicle controls & 1 & - \\
\hline Skipped estrus & $25 \%$ vs. vehicle controls & 1 & - \\
\hline Skipped estrus & $50 \%$ vs. vehicle controls & 1 & - \\
\hline Skipped diestrus & Overall & 1 & \\
\hline Skipped diestrus & $12.5 \%$ vs. vehicle controls & 1 & - \\
\hline Skipped diestrus & $25 \%$ vs. vehicle controls & 1 & - \\
\hline Skipped diestrus & $50 \%$ vs. vehicle controls & 1 & - \\
\hline
\end{tabular}


Table D-4. Summary of Reproductive Tissue Evaluations for Male Mice in the Three-month Dermal Study of Cedarwood Oil ${ }^{\mathrm{a}}$

\begin{tabular}{lcccc}
\hline & $\begin{array}{c}\text { Vehicle } \\
\text { Control }\end{array}$ & $\mathbf{6 . 2 5 \%}$ & $\mathbf{1 2 . 5 \%}$ & $\mathbf{2 5 \%}$ \\
\hline $\mathbf{n}$ & 10 & 10 & 9 & 10 \\
\hline Weights (g) & & & & \\
$\quad$ Necropsy body wt & $36.9 \pm 0.8$ & $36.0 \pm 0.6$ & $35.1 \pm 1.1$ & $33.1 \pm 0.9^{* *}$ \\
$\quad$ L. Cauda epididymis & $0.0161 \pm 0.0018$ & $0.0143 \pm 0.0009$ & $0.0143 \pm 0.0007$ & $0.0141 \pm 0.0005$ \\
$\quad$ L. Epididymis & $0.0436 \pm 0.0023$ & $0.0423 \pm 0.0015$ & $0.0396 \pm 0.0012$ & $0.0417 \pm 0.0011$ \\
$\quad$ L. Testis & $0.1089 \pm 0.0032$ & $0.1100 \pm 0.0022$ & $0.1092 \pm 0.0026$ & $0.1094 \pm 0.0025$ \\
Spermatid measurements & & & & \\
$\quad$ Spermatid heads (106/testis) & $21.57 \pm 0.72$ & $21.42 \pm 0.75$ & $22.85 \pm 0.60$ & $21.98 \pm 0.66^{\mathrm{b}}$ \\
$\quad$ Spermatid heads (106/g testis) & $210.41 \pm 9.00$ & $208.10 \pm 9.26$ & $214.88 \pm 5.46$ & $217.22 \pm 5.31^{\mathrm{b}}$ \\
Epididymal spermatozoal measurements & & & & \\
$\quad$ Sperm motility (\%) & $83.1 \pm 0.3$ & $81.6 \pm 1.9$ & $82.7 \pm 0.6$ & $83.9 \pm 0.4$ \\
$\quad$ Sperm (106/cauda epididymis) & $12.5 \pm 1.4$ & $12.6 \pm 1.1$ & $12.6 \pm 1.0$ & $13.3 \pm 2.1$ \\
$\quad$ Sperm (10 $/ g$ cauda epididymis) & $820.3 \pm 105.9$ & $884.7 \pm 70.4$ & $886.8 \pm 69.1$ & $1,022.9 \pm 121.2$ \\
\hline
\end{tabular}

**Significantly different $(\mathrm{P} \leq 0.01)$ from the vehicle control group by Williams' test.

a Data are presented as mean \pm standard error. Differences from the vehicle control group are not significant by Dunnett's test (tissue weights) or Dunn's test (spermatid and epididymal spermatozoal measurements). $\mathrm{b}_{\mathrm{n}}=9$.

Table D-5. Estrous Cycle Characterization for Female Mice in the Three-month Dermal Study of Cedarwood Oil ${ }^{\mathrm{a}}$

\begin{tabular}{lcccc}
\hline & $\begin{array}{c}\text { Vehicle } \\
\text { Control }\end{array}$ & $\mathbf{6 . 2 5 \%}$ & $\mathbf{1 2 . 5 \%}$ & $\mathbf{2 5 \%}$ \\
\hline Number weighed at necropsy & 10 & 10 & 10 & 10 \\
$\quad$ Necropsy body wt (g) & $34.7 \pm 1.1$ & $34.0 \pm 0.9$ & $30.5 \pm 0.7 * *$ & $28.1 \pm 0.6^{* * *}$ \\
Proportion of regular cycling females ${ }^{\mathrm{b}}$ & $8 / 10$ & $8 / 10$ & $9 / 10$ & $9 / 10$ \\
Estrous cycle length (days) & $4.2 \pm 0.14$ & $4.5 \pm 0.4$ & $3.9 \pm 0.09$ & $4.1 \pm 0.15$ \\
Estrous stages (\% of cycle) & & & & \\
Diestrus & 31.7 & 30.0 & 32.5 & 26.7 \\
Proestrus & 0.0 & 0.0 & 0.0 & 0.0 \\
Estrus & 45.0 & 45.8 & 45.8 & 45.0 \\
Metestrus & 21.7 & 24.2 & 21.7 & 24.2 \\
Uncertain diagnoses & 1.7 & 0.0 & 0.0 & 4.2 \\
\hline
\end{tabular}

**Significantly different $(\mathrm{P} \leq 0.01)$ from the vehicle control group by Williams' test.

${ }^{a}$ Necropsy body weights and estrous cycle length data are presented as mean \pm standard error. Differences from the vehicle control group are not significant by Dunn's test (estrous cycle length). By multivariate analysis of variance, dosed females do not differ significantly from the vehicle control females in the relative length of time spent in the estrous stages. Tests for equality of transition probability matrices among all groups and between the vehicle control group and each dosed group indicated no significant differences in transition probabilities among the groups.

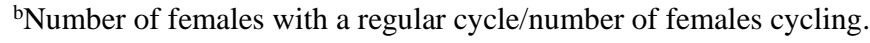


Table D-6. Results of Vaginal Cytology Study Using the Transition Matrix Approach for Female Mice in the Three-month Dermal Study of Cedarwood Oil

\begin{tabular}{|c|c|c|c|}
\hline Stage & Comparison & P Value & Trend $^{\mathrm{a}}$ \\
\hline Overall tests & Overall & 0.641 & \\
\hline Overall tests & $6.25 \%$ vs. vehicle controls & 0.828 & $\mathrm{~N}$ \\
\hline Overall tests & $12.5 \%$ vs. vehicle controls & 0.401 & $\mathrm{~N}$ \\
\hline Overall tests & $25 \%$ vs. vehicle controls & 0.358 & - \\
\hline Extended estrus & Overall & 0.848 & \\
\hline Extended estrus & $6.25 \%$ vs. vehicle controls & 0.758 & $\mathrm{~N}$ \\
\hline Extended estrus & $12.5 \%$ vs. vehicle controls & 0.347 & $\mathrm{~N}$ \\
\hline Extended estrus & $25 \%$ vs. vehicle controls & 0.994 & - \\
\hline Extended diestrus & Overall & 0.985 & \\
\hline Extended diestrus & $6.25 \%$ vs. vehicle controls & 0.882 & $\mathrm{~N}$ \\
\hline Extended diestrus & $12.5 \%$ vs. vehicle controls & 0.882 & $\mathrm{~N}$ \\
\hline Extended diestrus & $25 \%$ vs. vehicle controls & 0.777 & - \\
\hline Extended metestrus & Overall & 1 & \\
\hline Extended metestrus & $6.25 \%$ vs. vehicle controls & 1 & - \\
\hline Extended metestrus & $12.5 \%$ vs. vehicle controls & 1 & - \\
\hline Extended metestrus & $25 \%$ vs. vehicle controls & 1 & - \\
\hline Extended proestrus & Overall & 1 & \\
\hline Extended proestrus & $6.25 \%$ vs. vehicle controls & 1 & - \\
\hline Extended proestrus & $12.5 \%$ vs. vehicle controls & 1 & - \\
\hline Extended proestrus & $25 \%$ vs. vehicle controls & 1 & - \\
\hline Skipped estrus & Overall & 1 & \\
\hline Skipped estrus & $6.25 \%$ vs. vehicle controls & 1 & - \\
\hline Skipped estrus & $12.5 \%$ vs. vehicle controls & 1 & - \\
\hline Skipped estrus & $25 \%$ vs. vehicle controls & 1 & - \\
\hline Skipped diestrus & Overall & 1 & 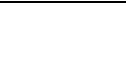 \\
\hline Skipped diestrus & $6.25 \%$ vs. vehicle controls & 1 & - \\
\hline Skipped diestrus & $12.5 \%$ vs. vehicle controls & 1 & - \\
\hline Skipped diestrus & $25 \%$ vs. vehicle controls & 1 & - \\
\hline
\end{tabular}




\begin{tabular}{|c|c|c|c|c|c|c|c|c|c|c|c|c|c|c|c|c|c|c|}
\hline $\begin{array}{c}\text { Concentration } \\
(\%)\end{array}$ & & & & & & & & & & & & & & & & & & \\
\hline Vehicle Control & & & & $\mathrm{D}$ & $\mathbf{P}$ & $\mathrm{E}$ & $\mathrm{D}$ & $\mathrm{D}$ & $\mathrm{D}$ & $\mathbf{P}$ & $E$ & $\mathrm{D}$ & $\mathrm{D}$ & $\mathrm{D}$ & $\mathbf{P}$ & & & \\
\hline Vehicle Control & & & & & $\mathbf{P}$ & $\mathrm{E}$ & $\mathrm{D}$ & $\mathrm{D}$ & $\mathrm{D}$ & $\mathbf{P}$ & $\mathrm{E}$ & $\mathrm{D}$ & $\mathrm{D}$ & $\mathrm{D}$ & $\mathbf{P}$ & $\mathrm{E}$ & & \\
\hline Vehicle Control & & & $\mathrm{D}$ & $\mathrm{D}$ & $\mathbf{P}$ & $\mathrm{E}$ & $\mathrm{D}$ & D & $\mathrm{D}$ & $\mathbf{P}$ & $\mathrm{E}$ & $\mathrm{D}$ & $\mathrm{D}$ & $\mathrm{D}$ & & & & \\
\hline Vehicle Control & & $\mathrm{D}$ & $\mathrm{D}$ & D & $\mathbf{P}$ & $\mathrm{E}$ & $\mathrm{D}$ & $\mathrm{D}$ & $\mathrm{D}$ & $\mathbf{P}$ & $\mathrm{E}$ & $\mathrm{D}$ & $\mathrm{D}$ & 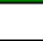 & & & & \\
\hline Vehicle Control & & & & & & $E$ & $\mathrm{D}$ & $\mathrm{D}$ & $\mathrm{D}$ & $\mathbf{P}$ & $E$ & $\mathrm{D}$ & $\mathrm{D}$ & $\mathrm{D}$ & $\mathbf{P}$ & E & $\mathrm{D}$ & \\
\hline Vehicle Control & & & $\mathrm{D}$ & $\mathrm{D}$ & $\mathbf{P}$ & $E$ & $\bar{D}$ & $\mathrm{D}$ & $\mathrm{D}$ & $\mathbf{P}$ & $E$ & $\bar{D}$ & $\mathrm{D}$ & $\mathrm{D}$ & 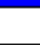 & 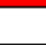 & 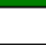 & \\
\hline Vehicle Control & & & & & & $\mathrm{E}$ & $\mathrm{D}$ & $\mathrm{D}$ & $\mathrm{D}$ & $\mathbf{P}$ & $\mathrm{E}$ & $\mathrm{D}$ & $\mathrm{D}$ & $\mathrm{D}$ & $\mathbf{P}$ & $\mathrm{E}$ & $\mathrm{D}$ & \\
\hline Vehicle Control & & & & $\mathrm{D}$ & $\mathbf{P}$ & $\mathrm{E}$ & $\mathrm{D}$ & $\mathrm{D}$ & $\mathrm{D}$ & $\mathbf{P}$ & $E$ & $\mathrm{D}$ & $\mathrm{D}$ & $\mathrm{D}$ & $\mathbf{P}$ & & & \\
\hline Vehicle Control & & & & $\mathrm{D}$ & $\mathbf{P}$ & $E$ & $\mathrm{D}$ & $\mathrm{D}$ & $\mathrm{D}$ & $\mathbf{P}$ & $E$ & $\mathrm{D}$ & $\mathrm{D}$ & $\mathrm{D}$ & $\mathbf{P}$ & & & \\
\hline Vehicle Control & & D & D & $\mathrm{D}$ & $\mathbf{P}$ & $\mathrm{E}$ & $\mathrm{D}$ & $\mathrm{D}$ & D & P & E & D & $\bar{D}$ & & & & & \\
\hline & & & & & & & & & & & 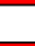 & & & & & & & \\
\hline 12.5 & & & & 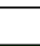 & & $E$ & D & D & D & $P$ & $E$ & D & $\mathrm{D}$ & D & P & E & D & \\
\hline 12.5 & & & $\mathrm{D}$ & $\mathrm{D}$ & $\mathbf{P}$ & $E$ & D & $\mathrm{D}$ & D & P & $\mathrm{E}$ & D & D & D & & & & \\
\hline 12.5 & & & & D & $P$ & $E$ & D & D & $\mathrm{D}$ & $\mathbf{P}$ & $E$ & D & $\mathrm{D}$ & $\mathrm{D}$ & $\mathbf{P}$ & & & \\
\hline 12.5 & & & $\mathrm{D}$ & $\mathrm{D}$ & $\mathbf{P}$ & $E$ & D & D & D & $\mathbf{P}$ & $E$ & $\mathrm{D}$ & $\mathrm{D}$ & D & & & & \\
\hline 12.5 & & & D & D & P & $E$ & D & D & D & P & $E$ & $\bar{D}$ & D & D & & & & \\
\hline 12.5 & & & 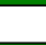 & 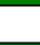 & $\mathbf{P}$ & $E$ & D & D & $\mathrm{D}$ & $\mathbf{P}$ & $E$ & $\mathrm{D}$ & $\mathrm{D}$ & $\mathrm{D}$ & $\mathbf{P}$ & E & & \\
\hline 12.5 & & & $\mathrm{D}$ & $\mathrm{D}$ & $\mathbf{P}$ & $E$ & $\mathrm{D}$ & $\mathrm{D}$ & $\mathrm{D}$ & $\mathbf{P}$ & $E$ & $\mathrm{D}$ & $\mathrm{D}$ & D & & & & \\
\hline 12.5 & & & 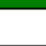 & D & IC & $E$ & D & D & D & P & $E$ & $\bar{D}$ & D & D & $\mathbf{P}$ & & & \\
\hline 12.5 & & $\mathrm{D}$ & $\mathrm{D}$ & D & $\mathbf{P}$ & $E$ & D & D & $\mathrm{D}$ & $\mathbf{P}$ & $E$ & D & $\mathrm{D}$ & 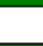 & - & & & \\
\hline 12.5 & & & & & D & $\mathrm{D}$ & $\mathrm{E}$ & $\mathrm{D}$ & D & D & E & $E$ & D & $\mathrm{D}$ & $\mathrm{D}$ & $P$ & & \\
\hline & & & & & & 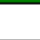 & . & 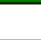 & 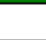 & & . & 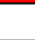 & . & 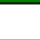 & & 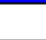 & & \\
\hline 25 & & $\mathrm{D}$ & $\mathrm{D}$ & $\mathrm{D}$ & $P$ & $E$ & $\mathrm{D}$ & $\mathrm{D}$ & $\mathrm{D}$ & $P$ & E & $\mathrm{D}$ & $\mathrm{D}$ & 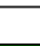 & & & & \\
\hline 25 & & & & & $\mathbf{P}$ & $E$ & D & D & $\mathrm{D}$ & $\mathbf{P}$ & $E$ & D & D & D & $\mathbf{P}$ & E & & \\
\hline 25 & & & & & P & $E$ & $\mathrm{D}$ & D & $\mathrm{D}$ & D & $E$ & D & $\mathrm{D}$ & D & $\mathbf{P}$ & $\mathrm{E}$ & & \\
\hline 25 & IC & IC & $\mathrm{D}$ & $\mathrm{D}$ & $\mathbf{P}$ & $E$ & D & D & D & P & $E$ & D & 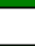 & 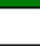 & & & & \\
\hline 25 & & $\mathrm{D}$ & $\mathrm{D}$ & D & $\mathrm{P}$ & $E$ & D & D & $\mathrm{D}$ & $\mathbf{P}$ & $E$ & D & $\mathrm{D}$ & 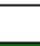 & & & & \\
\hline 25 & & & & 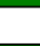 & P & $E$ & $\mathrm{D}$ & D & D & D & $E$ & $\mathrm{D}$ & $\mathrm{D}$ & $\mathrm{D}$ & $\mathbf{P}$ & $\mathrm{E}$ & & \\
\hline 25 & & $\mathrm{D}$ & $\mathrm{D}$ & $\mathrm{D}$ & $P$ & $E$ & D & D & D & $\mathbf{P}$ & $E$ & D & $\mathrm{D}$ & 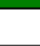 & & & & \\
\hline 25 & & & D & D & $P$ & $E$ & $\mathrm{D}$ & $\mathrm{D}$ & $\mathrm{D}$ & $\mathbf{P}$ & $E$ & $\mathrm{D}$ & $\mathrm{D}$ & D & & & & \\
\hline 25 & & & & D & E & $\mathrm{D}$ & D & D & $\mathrm{D}$ & $\mathbf{P}$ & $E$ & D & D & D & $\mathrm{D}$ & & & \\
\hline 25 & & $\mathrm{D}$ & $\mathrm{D}$ & D & $\mathbf{P}$ & $E$ & D & $D$ & D & $\mathbf{P}$ & E & D & D & - & & & & \\
\hline & & & & & & & & & & & & & & & & & & \\
\hline 50 & & & & & & $E$ & D & $\mathrm{D}$ & $\mathrm{D}$ & $\mathbf{P}$ & $E$ & D & D & $\mathrm{D}$ & $P$ & $\mathrm{E}$ & $\mathrm{D}$ & \\
\hline 50 & & & & & & $E$ & D & D & $\mathrm{D}$ & $\mathbf{P}$ & $E$ & $\mathrm{D}$ & $\mathrm{D}$ & D & $\mathbf{P}$ & $\mathrm{E}$ & $\mathrm{D}$ & \\
\hline 50 & & & & $\mathrm{D}$ & $\mathbf{P}$ & $E$ & D & $\mathrm{D}$ & $\mathrm{D}$ & $\mathbf{P}$ & $E$ & $\mathrm{D}$ & D & $\mathrm{D}$ & $\mathbf{P}$ & & & \\
\hline 50 & & & & D & $\mathrm{P}$ & $\mathrm{E}$ & D & D & $\mathrm{D}$ & $\mathbf{P}$ & $E$ & D & $\mathrm{D}$ & D & $\mathbf{P}$ & & & \\
\hline 50 & & & & & & $E$ & D & D & $\mathrm{D}$ & $\mathbf{P}$ & $E$ & D & $\mathrm{D}$ & D & $\mathbf{P}$ & $E$ & $\mathrm{D}$ & \\
\hline 50 & & & & & $\mathbf{P}$ & $E$ & $\mathrm{D}$ & $\mathrm{D}$ & $\mathrm{D}$ & $\mathbf{P}$ & $\mathrm{E}$ & $\mathrm{D}$ & $\mathrm{D}$ & $\mathrm{D}$ & $\mathbf{P}$ & $\mathrm{E}$ & & \\
\hline 50 & & & & & $\mathbf{P}$ & $E$ & D & D & D & $\mathbf{P}$ & $E$ & $\mathrm{D}$ & $\mathrm{D}$ & $\bar{D}$ & $\mathbf{P}$ & $E$ & & \\
\hline 50 & IC & IC & $\mathrm{D}$ & D & $\mathbf{P}$ & $E$ & $\mathrm{D}$ & $\mathrm{D}$ & $\mathrm{D}$ & $\mathbf{P}$ & $E$ & $\mathrm{D}$ & 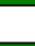 & 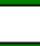 & & 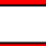 & & \\
\hline 50 & & & & & $\mathbf{P}$ & $E$ & $\mathrm{D}$ & $\mathrm{D}$ & $\mathrm{D}$ & $\mathbf{P}$ & $\mathrm{E}$ & $\mathrm{D}$ & $\mathrm{D}$ & $\mathrm{D}$ & $\mathbf{P}$ & $\mathrm{E}$ & & \\
\hline 50 & & & & & D & $\mathbf{P}$ & $\mathrm{E}$ & $\mathrm{D}$ & $\mathrm{D}$ & D & $\mathrm{E}$ & $\mathrm{E}$ & $\mathrm{D}$ & $\mathrm{D}$ & $\mathrm{D}$ & $\mathbf{P}$ & & \\
\hline
\end{tabular}

Figure D-1. Vaginal Cytology Plots for Female Rats in the Three-month Dermal Study of Cedarwood Oil

$\mathrm{D}=$ diestrus, $\mathrm{P}=$ proestrus, $\mathrm{E}=$ estrus, $\mathrm{IC}=$ insufficient number of cells to determine stage. 


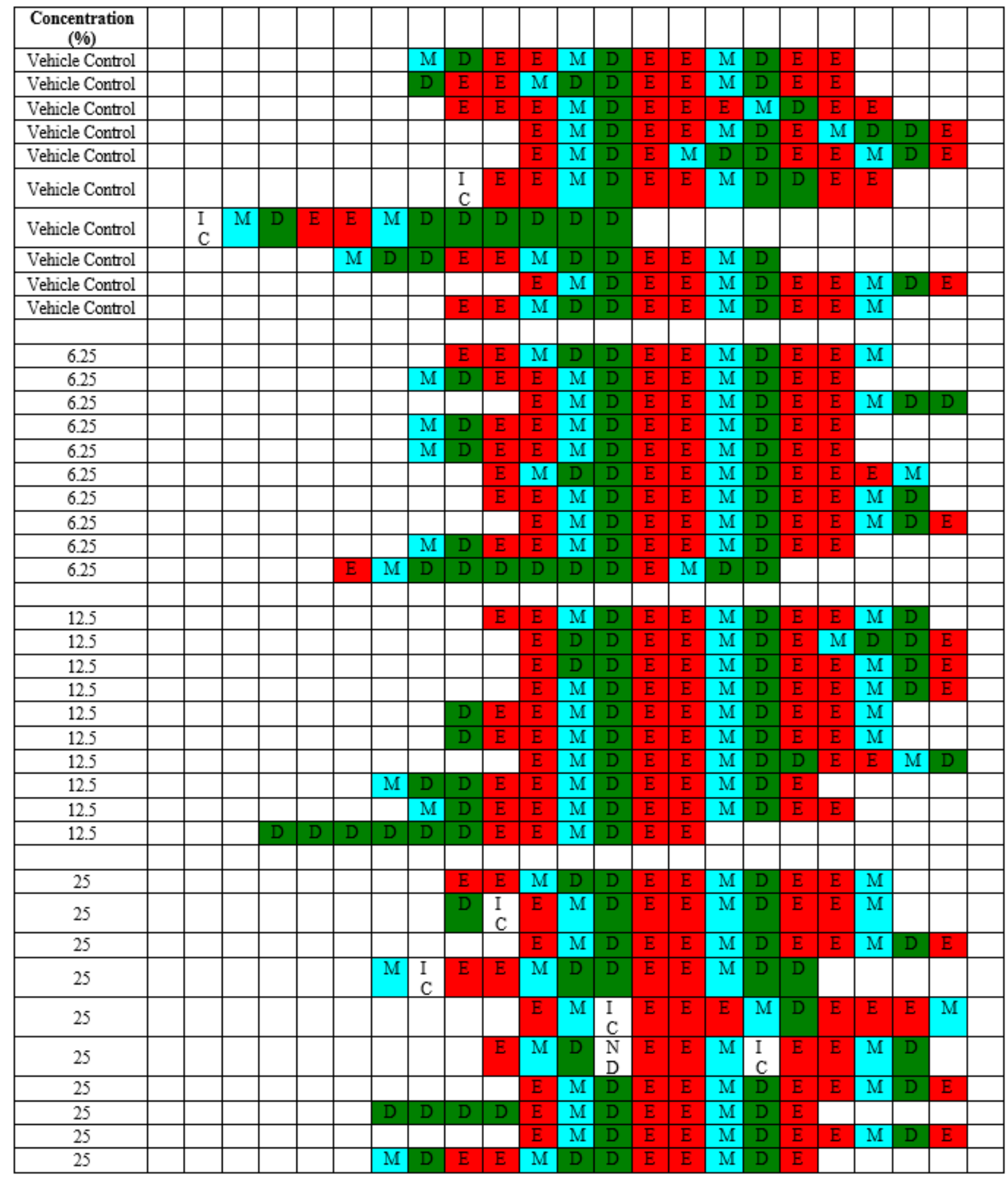

Figure D-2. Vaginal Cytology Plots for Female Mice in the Three-month Dermal Study of Cedarwood Oil

$\mathrm{D}=$ diestrus, $\mathrm{E}$ = estrus, $\mathrm{M}=$ metestrus, $\mathrm{IC}$ = insufficient number of cells to determine stage. 


\section{Appendix E. Genetic Toxicology}

\section{Tables}

Table E-1. Mutagenicity of Cedarwood Oil in Salmonella typhimurium .................................E-2

Table E-2. Frequency of Micronuclei in Peripheral Blood Erythrocytes of Mice

Following Dermal Administration of Cedarwood Oil for Three Months....................-3 
Cedarwood Oil, NTP TOX 86

Table E-1. Mutagenicity of Cedarwood Oil in Salmonella typhimurium ${ }^{\mathrm{a}}$

\begin{tabular}{|c|c|c|c|}
\hline Strain & $\begin{array}{c}\text { Dose } \\
(\mu \mathrm{g} / \mathrm{plate})\end{array}$ & Without S9 & $\begin{array}{c}\text { With } 10 \% \\
\text { Rat S9 }\end{array}$ \\
\hline \multirow[t]{8}{*}{ TA102 } & 0 & $315 \pm 14$ & $405 \pm 6$ \\
\hline & 0.33 & $278 \pm 6$ & \\
\hline & 1.0 & $298 \pm 3$ & \\
\hline & 3.3 & $282 \pm 6$ & $421 \pm 3$ \\
\hline & 10 & $311 \pm 17$ & $401 \pm 10$ \\
\hline & 33 & $240 \pm 12$ & $404 \pm 9$ \\
\hline & 100 & & $386 \pm 16$ \\
\hline & 333 & & $346 \pm 2$ \\
\hline Trial summary & & Negative & Negative \\
\hline Positive control ${ }^{\mathrm{b}}$ & & $976 \pm 7$ & $1,398 \pm 55$ \\
\hline \multirow[t]{8}{*}{ TA100 } & 0 & $160 \pm 10$ & $152 \pm 14$ \\
\hline & 0.33 & $145 \pm 3$ & \\
\hline & 1.0 & $144 \pm 6$ & \\
\hline & 3.3 & $141 \pm 9$ & $142 \pm 2$ \\
\hline & 10 & $126 \pm 4$ & $136 \pm 8$ \\
\hline & 33 & $31 \pm 11^{\mathrm{c}}$ & $145 \pm 2$ \\
\hline & 100 & & $124 \pm 10$ \\
\hline & 333 & & $85 \pm 7^{c}$ \\
\hline Trial summary & & Negative & Negative \\
\hline Positive control & & $630 \pm 13$ & $512 \pm 86$ \\
\hline \multirow[t]{8}{*}{ TA98 } & 0 & $21 \pm 3$ & $34 \pm 1$ \\
\hline & 0.33 & $17 \pm 2$ & \\
\hline & 1.0 & $16 \pm 2$ & \\
\hline & 3.3 & $26 \pm 2$ & $31 \pm 3$ \\
\hline & 10 & $22 \pm 4^{\mathrm{d}}$ & $27 \pm 6$ \\
\hline & 33 & $14 \pm 2^{c}$ & $34 \pm 3$ \\
\hline & 100 & & $34 \pm 4$ \\
\hline & 333 & & $0 \pm 0^{c}$ \\
\hline Trial summary & & Negative & Negative \\
\hline Positive control & & $83 \pm 4$ & $676 \pm 3$ \\
\hline
\end{tabular}

aStudy was performed at BioReliance Corporation. The detailed protocol is presented by Zeiger et al. ${ }^{54}$. Data are presented as revertants/plate (mean \pm standard error) from three plates. $0 \mu \mathrm{g} /$ plate was the solvent control.

${ }^{\mathrm{b}}$ The positive controls in the absence of metabolic activation were sodium azide (TA100), 4-nitro-o-phenylenediamine (TA98), and methyl methanesulfonate (TA102). The positive control for metabolic activation with all strains was 2-aminoanthracene.

'Slight toxicity.

${ }^{\mathrm{d}}$ Contamination. 
Table E-2. Frequency of Micronuclei in Peripheral Blood Erythrocytes of Mice Following Dermal Administration of Cedarwood Oil for Three Months ${ }^{\text {a }}$

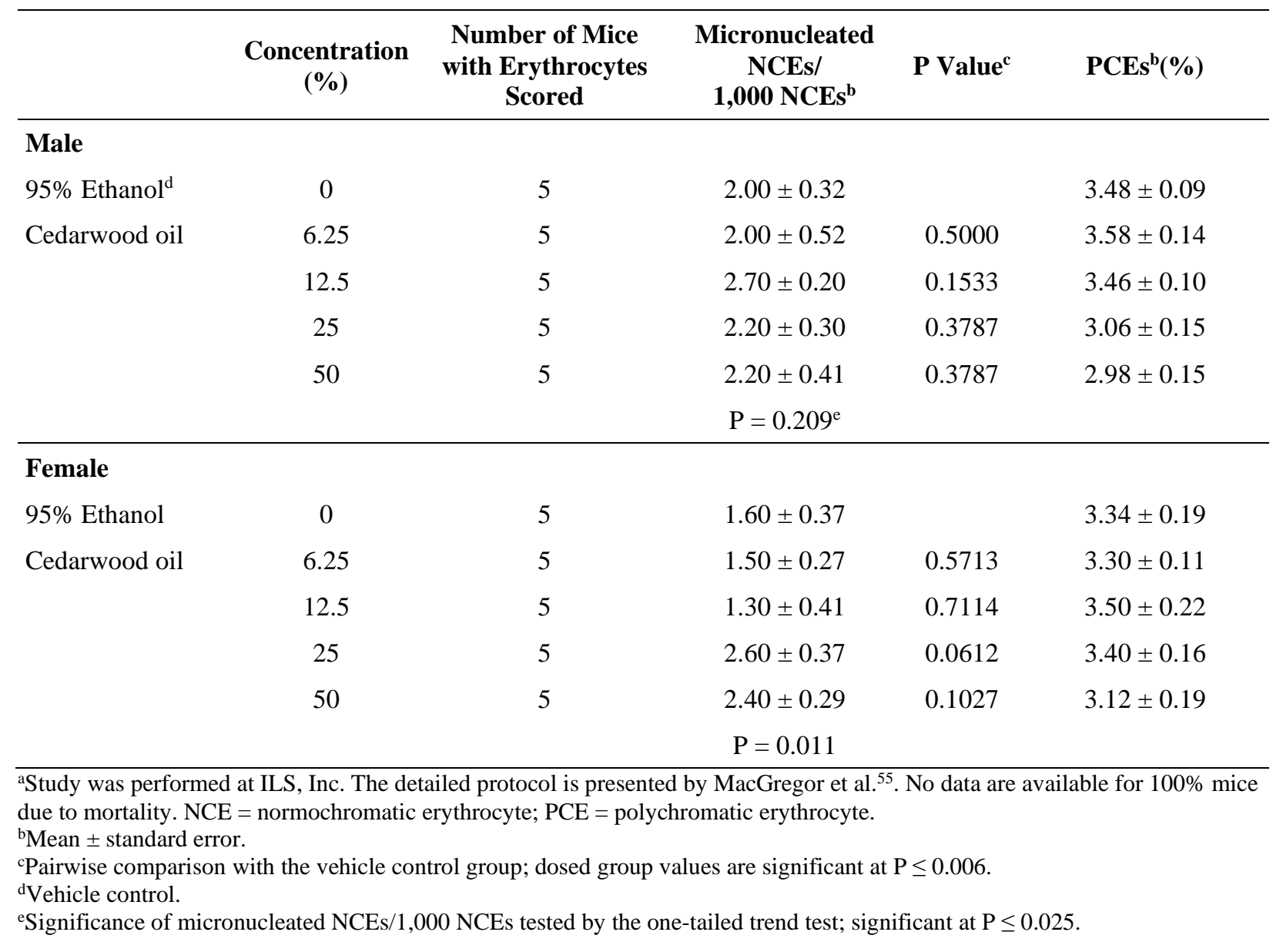




\section{Appendix F. Chemical Characterization and Dose Formulation Studies}

\section{Table of Contents}

F.1. Procurement and Characterization...................................................................................

F.2. Preparation and Analysis of Dose Formulations ........................................................

\section{Tables}

Table F-1. Gas Chromatography Systems Used in the Three-month Dermal Studies of Cedarwood Oil

Table F-2. Preparation and Storage of Dose Formulations in the Three-month Dermal Studies of Cedarwood Oil

Table F-3. Results of Analyses of Dose Formulations Administered to Rats and Mice in the Three-month Dermal Studies of Cedarwood Oil

\section{Figures}

Figure F-1. Infrared Absorption Spectrum of Cedarwood Oil 


\section{F.1. Procurement and Characterization}

\section{F.1.1. Cedarwood Oil}

Prior to selecting the test article, NTP investigated the composition of selected components in six lots that were procured as Virginia cedarwood oil from three suppliers. The chromatographic profiles of the six lots were similar to each other. The composition of $\alpha$-cedrene, $\beta$-cedrene, thujopsene, cuparene, and cedrol in these lots ranged from $18 \%$ to $40 \%, 4 \%$ to $8 \%, 16 \%$ to $31 \%$, $2 \%$ to $4 \%$, and $19 \%$ to $26 \%$, respectively. Due to the close similarities between the procured lots, the lot selected for testing was based upon the availability in bulk quantity.

For the current 3-month dermal studies, cedarwood oil was obtained from Texarome, Inc. (Leakey, TX), in one lot (T122303DP). Identity, purity, and stability analyses were conducted by the analytical chemistry laboratory at Midwest Research Institute (Kansas City, MO) and the study laboratory at Battelle Columbus Operations (Columbus, $\mathrm{OH}$ ). Reports on analyses performed in support of the cedarwood oil studies are on file at the National Institute of Environmental Health Sciences.

The chemical, a pale yellow oily liquid with a cedar odor, was identified as cedarwood oil by the analytical chemistry laboratory using infrared (IR) and proton nuclear magnetic resonance (NMR) spectroscopy and by the study laboratory using IR spectroscopy. All IR spectra were consistent with the literature spectra for cedarwood oil ${ }^{67}$; NMR spectra were consistent with spectra previously obtained from another lot of cedarwood oil. Representative IR and NMR spectra are presented in Figure F-1 and Figure F-2, respectively.

Physical properties for lot T122303DP were determined by the analytical chemistry laboratory; optical rotation was $-26.1^{\circ}$, specific gravity was 0.9581 at $24.8^{\circ} \mathrm{C}$, refractive index was 1.5053 at $19^{\circ} \mathrm{C}$, and viscosity was $22.6 \mathrm{cP}$ at $22.2^{\circ} \mathrm{C}$. The determined values for optical rotation, specific gravity, and refractive index were consistent with the reported values for cedarwood oil ${ }^{37}$.

The purity of lot T122303DP was determined by the analytical chemistry laboratory based on a chromatography profile of the major components obtained by using gas chromatography (GC) with flame ionization detection (FID) by system A (Table F-1). Five compounds ( $\alpha$-cedrene, $\beta$ cedrene, thujopsene, cuparene, and cedrol) were selected as marker compounds and quantitated using standards obtained from Sigma-Aldrich Corporation (St. Louis, MO). Weight percent concentrations of the five selected marker compounds were determined to be $\alpha$-cedrene, $27.01 \%$, $\beta$-cedrene, $6.05 \%$, thujopsene, $19.64 \%$, cuparene, $0.96 \%$, and cedrol, $21.83 \%$; these results were not significantly changed by homogenization of the bulk chemical (heating to $50^{\circ} \mathrm{C}$ ) prior to analysis.

The analytical chemistry laboratory also determined the components of lot T122303DP using GC with mass spectrometry (MS) detection by system B to profile the major components of the test article. Ten marker compounds having peak areas of at least $1 \%$ of the total peak area were identified in this analysis; $\alpha$-cedrene, $\beta$-cedrene, thujopsene, $\beta$-chamigrene, $\alpha$-alaskene, $\alpha$ cuprenene, $\beta$-himachalene, cuparene, cedrol, and widdrol. Headspace analysis for volatiles were conducted on samples of this lot using GC/MS by system B both before and after homogenization at $50^{\circ} \mathrm{C}$, and 15 components were identified in the chromatographic profiles: limonene (or an isomer), iso-italicene (or an isomer), italicene (or an isomer), $\alpha$-cedrene, cis- $\beta$ farnesene (or an isomer), $\beta$-selinene (or an isomer), $\beta$-cedrene, thujopsene, $\beta$-chamigrene (or an 
isomer), $\alpha$-alaskene (or an isomer), $\alpha$-cuprenene (or an isomer), $\beta$-himachalene (or an isomer), cuparene, cedrol, and widdrol. No significant differences were observed between samples analyzed before and after homogenization. Taken together, the results of these characterization assays indicated that the composition of lot T122303DP was consistent with that reported in the literature for cedarwood oil ${ }^{37-39}$.

One aliquot of cedarwood oil was submitted to Covance Laboratories, Inc. (Madison, WI) for nutritional and contaminant testing using standard methods. For this lot, mercury and molybdenum were detected at $13.2 \mathrm{ppb}$ and $18.2 \mathrm{ppb}$, respectively. The other metals (antimony, arsenic, cadmium, and lead) were below the limit of quantitation of the assay ( $<10 \mathrm{ppb})$. For mycotoxin analyses, levels of aflatoxins B1, B2, G1, and G2 were all less than 0.500 ppb; levels of ochratoxin and zearalinine were less than 1 and $20 \mathrm{ppb}$, respectively. The pesticide screen experienced significant matrix effects that prevented quantitation of analytes.

Stability studies of the bulk chemical were performed by the analytical chemistry laboratory. GC/FID was performed using system A for samples stored at $-20^{\circ}, 5^{\circ}, 25^{\circ}$, or $60^{\circ} \mathrm{C}$ in sealed amber glass vials; additional freeze/thaw analyses were also performed every 2 to 3 days during the 2-week stability studies. Stability was confirmed for at least 2 weeks for samples stored at temperatures up to $25^{\circ} \mathrm{C}$ in sealed amber glass vials. Freeze/thaw analyses indicated no decomposition due to repeated freezing and thawing.

To ensure stability, the bulk chemical was stored at approximately $25^{\circ} \mathrm{C}$ in the original sealed amber glass shipping bottles. Periodic reanalyses of the bulk chemical were performed by the study laboratory during the 3-month studies using GC/FID by system A; no degradation of the bulk chemical was detected.

\section{F.1.2. Ethanol}

USP grade 95\% ethanol was obtained from Spectrum Chemicals \& Laboratory Products (Gardena, CA) in one lot (TP0179) and from AAPER Alcohol (Shelbyville, KY) in one lot (02K2JWB). Lot TP0179 was used in the 3-month dermal studies, and lot 02K2JWB was used in the dose formulation stability studies.

Lot TP0179, a clear liquid, was identified as ethanol by the study laboratory using IR spectroscopy; the IR spectrum was consistent with a literature spectrum ${ }^{68}$ of ethanol. The purity of lot TP0179 was determined by the study laboratory using GC/FID by system C; no impurities greater than $0.1 \%$ of the total peak area were detected. No benzene was detected in the test article using GC/FID by system D.

\section{F.2. Preparation and Analysis of Dose Formulations}

The dose formulations were prepared four times by mixing cedarwood oil and $95 \%$ ethanol to give the required concentrations (Table F-2). The dose formulations were stored at approximately $25^{\circ} \mathrm{C}$ in amber glass bottles sealed with Teflon ${ }^{\circledR}$-lined lids for up to 34 days.

Stability studies of a $9.5 \mathrm{mg} / \mathrm{mL}$ (0.95\%) formulation in $95 \%$ ethanol were performed by the analytical chemistry laboratory using GC/FID by system E (Table F-1). Based on these studies, it was determined that cedarwood oil formulations could be stored in amber glass containers sealed with Teflon ${ }^{\circledR}$-lined lids for 1 day with expected losses of $6.2 \%$ or less for all components or 
stored for 42 days with expected losses of $10.4 \%$ or less. Cedarwood oil formulations were stable for up to 3 hours under simulated animal room conditions.

Periodic analyses of the dose formulations of cedarwood oil were conducted by the study laboratory using GC/FID by a system similar to system E. During the 3-month studies, the dose formulations were analyzed three times; all 15 dose formulations analyzed for rats and all 14 dose formulations for mice were within $10 \%$ of the target concentrations (Table F-3). Animal room samples of these dose formulations were also analyzed; all 15 for rats and all 14 for mice were within $10 \%$ of the target concentrations.

Table F-1. Gas Chromatography Systems Used in the Three-month Dermal Studies of Cedarwood Oil $^{\mathbf{a}}$

\begin{tabular}{|c|c|c|c|}
\hline Detection System & Column & Carrier Gas & $\begin{array}{c}\text { Oven Temperature } \\
\text { Program }\end{array}$ \\
\hline \multicolumn{4}{|l|}{ System A } \\
\hline Flame ionization & $\begin{array}{l}\text { DB-WAX, } \\
30 \mathrm{~m} \times 0.53 \mathrm{~mm}, 1.0 \mu \mathrm{m} \\
\text { film (J\&W Scientific, } \\
\text { Folsom, CA) }\end{array}$ & Helium at $10 \mathrm{~mL} /$ minute & $\begin{array}{l}60^{\circ} \mathrm{C} \text { for } 2 \text { minutes, then } \\
3^{\circ} \mathrm{C} / \text { minute to } 220^{\circ} \mathrm{C}\end{array}$ \\
\hline \multicolumn{4}{|l|}{ System B } \\
\hline Mass spectrometry & $\begin{array}{l}\text { DB-WAX, } \\
30 \mathrm{~m} \times 0.25 \mathrm{~mm}, 0.5 \mu \mathrm{m} \\
\text { film (J\&W Scientific) }\end{array}$ & Helium at $1 \mathrm{~mL} /$ minute & $\begin{array}{l}60^{\circ} \mathrm{C} \text { for } 3 \text { minutes, then } \\
3^{\circ} \mathrm{C} / \text { minute to } 220^{\circ} \mathrm{C}\end{array}$ \\
\hline \multicolumn{4}{|l|}{ System C } \\
\hline Flame ionization & $\begin{array}{l}\text { DB-WAX, } \\
30 \mathrm{~m} \times 0.53 \mathrm{~mm}, 1.0 \mu \mathrm{m} \\
\text { film (J\&W Scientific) }\end{array}$ & Helium at $10 \mathrm{~mL} / \mathrm{minute}$ & $\begin{array}{l}40^{\circ} \mathrm{C} \text { for } 5 \text { minutes, then } \\
10^{\circ} \mathrm{C} / \text { minute to } 220^{\circ} \mathrm{C} \text {, held } \\
\text { for } 5 \text { minutes }\end{array}$ \\
\hline \multicolumn{4}{|l|}{ System D } \\
\hline Flame ionization & $\begin{array}{l}\text { Rtx }^{\circledR}-5,30 \mathrm{~m} \times 0.53 \mathrm{~mm}, \\
1.5 \mu \mathrm{m} \text { film (Restek, } \\
\text { Bellefonte, PA) }\end{array}$ & Helium at $10 \mathrm{~mL} / \mathrm{minute}$ & $\begin{array}{l}40^{\circ} \mathrm{C} \text { for } 3 \text { minutes, then } \\
10^{\circ} \mathrm{C} / \text { minute to } 200^{\circ} \mathrm{C} \text {, held } \\
\text { for } 3 \text { minutes }\end{array}$ \\
\hline \multicolumn{4}{|l|}{ System E } \\
\hline Flame ionization & $\begin{array}{l}\text { DB-WAX, } \\
30 \mathrm{~m} \times 0.53 \mathrm{~mm}, 1.0 \mu \mathrm{m} \\
\text { film (J\&W Scientific) }\end{array}$ & Helium at $10 \mathrm{~mL} / \mathrm{minute}$ & $\begin{array}{l}60^{\circ} \mathrm{C} \text { for } 3 \text { minutes, then } \\
3^{\circ} \mathrm{C} / \text { minute to } 220^{\circ} \mathrm{C} \text {, held } \\
\text { for } 2 \text { minutes }\end{array}$ \\
\hline
\end{tabular}

aThe gas chromatographs were manufactured by Agilent Technologies, Inc. (Santa Clara, CA; systems A, C, D, and E) or Thermo Fisher Scientific, Inc., (Waltham, MA; system B). The mass spectrometer was manufactured by Fisons (Sanofi, Bridgewater, NJ). 
Table F-2. Preparation and Storage of Dose Formulations in the Three-month Dermal Studies of Cedarwood Oil

\section{Three-month Study}

\section{Preparation}

For the $6.25 \%, 12.5 \%, 25 \%$, and $50 \%$ formulations, the appropriate amount of cedarwood oil was measured in a graduated cylinder and transferred with at least three ethanol rinses into a calibrated mixing container that contained 95\% ethanol, diluted to a final volume with 95\% ethanol, shaken by hand for 2 minutes, inverted at least 10 times, and then stirred on a stirplate for approximately 5 minutes at a speed that produced a vigorous vortex. Undiluted cedarwood oil was dispensed directly into amber glass dose formulation bottles as the $100 \%$ (neat) formulation. The dose formulations were prepared four times during the studies.

\section{Chemical Lot Number}

T122303DP

\section{Maximum Storage Time}

34 days

\section{Storage Conditions}

Stored in amber glass bottles sealed with Teflon ${ }^{\circledR}$-lined lids at approximately $25^{\circ} \mathrm{C}$.

\section{Study Laboratory}

Battelle Columbus Operations (Columbus, $\mathrm{OH}$ )

Table F-3. Results of Analyses of Dose Formulations Administered to Rats and Mice in the Threemonth Dermal Studies of Cedarwood Oil ${ }^{\mathrm{a}}$

\begin{tabular}{|c|c|c|c|c|}
\hline Date Prepared & Date Analyzed & $\begin{array}{c}\text { Target } \\
\text { Concentration } \\
\text { (\%) }\end{array}$ & $\begin{array}{c}\text { Determined } \\
\text { Concentration } \\
(\%)\end{array}$ & $\begin{array}{c}\text { Difference } \\
\text { from Target } \\
(\%)\end{array}$ \\
\hline \multicolumn{5}{|l|}{ Rats } \\
\hline \multirow[t]{10}{*}{ May 31, 2005} & June 3-4, 2005 & 6.25 & 6.244 & 0 \\
\hline & & 12.5 & 12.31 & -2 \\
\hline & & 25 & 25.20 & +1 \\
\hline & & 50 & 53.20 & +6 \\
\hline & & 100 & 101.8 & +2 \\
\hline & July $8-10,2005^{c}$ & 6.25 & 6.291 & +1 \\
\hline & & 12.5 & 12.65 & +1 \\
\hline & & 25 & 25.75 & +3 \\
\hline & & 50 & 52.15 & +4 \\
\hline & July $11-12,2005^{c}$ & 100 & 97.87 & -2 \\
\hline \multirow[t]{5}{*}{ June 23, 2005} & June 24-25, 2005 & 6.25 & 6.071 & -3 \\
\hline & & 12.5 & 12.20 & -2 \\
\hline & & 25 & 24.69 & -1 \\
\hline & & 50 & 50.11 & 0 \\
\hline & & 100 & 99.63 & 0 \\
\hline
\end{tabular}




\begin{tabular}{|c|c|c|c|c|}
\hline Date Prepared & Date Analyzed & $\begin{array}{c}\text { Target } \\
\text { Concentration } \\
\text { (\%) }\end{array}$ & $\begin{array}{c}\text { Determined } \\
\text { Concentration } \\
(\%)\end{array}$ & $\begin{array}{c}\text { Difference } \\
\text { from Target } \\
(\%)\end{array}$ \\
\hline \multirow{15}{*}{ August 16, 2005} & \multirow[t]{5}{*}{ July $27-29,2005^{c}$} & 6.25 & 6.213 & -1 \\
\hline & & 12.5 & 12.25 & -2 \\
\hline & & 25 & 25.01 & 0 \\
\hline & & 50 & 49.53 & -1 \\
\hline & & 100 & 97.89 & -2 \\
\hline & \multirow[t]{5}{*}{ August 16-17, 2005} & 6.25 & 6.209 & -1 \\
\hline & & 12.5 & 11.97 & -4 \\
\hline & & 25 & 23.68 & -5 \\
\hline & & 50 & 49.21 & -2 \\
\hline & & 100 & 93.85 & -6 \\
\hline & \multirow[t]{5}{*}{ September 19-22, 2005c } & 6.25 & 6.380 & +2 \\
\hline & & 12.5 & 12.79 & +2 \\
\hline & & 25 & 25.46 & +2 \\
\hline & & 50 & 52.34 & +5 \\
\hline & & 100 & 101.2 & +1 \\
\hline \multicolumn{5}{|l|}{ Mice } \\
\hline \multirow[t]{10}{*}{ May 31, 2005} & \multirow[t]{5}{*}{ June 3-4, 2005} & 6.25 & 6.244 & 0 \\
\hline & & 12.5 & 12.31 & -2 \\
\hline & & 25 & 25.20 & +1 \\
\hline & & 50 & 53.20 & +6 \\
\hline & & 100 & 101.8 & +2 \\
\hline & \multirow[t]{4}{*}{ July $8-10,2005^{d}$} & 6.25 & 6.256 & 0 \\
\hline & & 12.5 & 12.59 & +1 \\
\hline & & 25 & 25.64 & +3 \\
\hline & & 50 & 53.00 & +6 \\
\hline & July $11-12,2005^{d}$ & 100 & 98.54 & -1 \\
\hline \multirow[t]{9}{*}{ June 23, 2005} & \multirow[t]{5}{*}{ June 24-25, 2005} & 6.25 & 6.071 & -3 \\
\hline & & 12.5 & 12.20 & -2 \\
\hline & & 25 & 24.69 & -1 \\
\hline & & 50 & 50.11 & 0 \\
\hline & & 100 & 99.63 & 0 \\
\hline & \multirow[t]{4}{*}{ July $27-29,2005^{d}$} & 6.25 & 5.929 & -5 \\
\hline & & 12.5 & 11.84 & -5 \\
\hline & & 25 & 23.87 & -5 \\
\hline & & 50 & 47.41 & -5 \\
\hline
\end{tabular}




\begin{tabular}{ccccc}
\hline Date Prepared & Date Analyzed & $\begin{array}{c}\text { Target } \\
\text { Concentration } \\
\mathbf{( \% )}\end{array}$ & $\begin{array}{c}\text { Determined } \\
\text { Concentration } \\
\mathbf{( \% )}\end{array}$ & $\begin{array}{c}\text { Difference } \\
\text { from Target } \\
\text { (\%) }\end{array}$ \\
\hline \multirow{2}{*}{ August 16, 2005 } & 100 & 93.06 & -7 \\
& August 16-17, 2005 & 6.25 & 6.209 & -1 \\
& & 12.5 & 11.97 & -4 \\
& September 19-22, 2005 & 25 & 23.68 & -5 \\
& & 50 & 49.21 & -2 \\
& 6.25 & 6.377 & +2 \\
& 12.5 & 12.82 & +3 \\
& 25 & 25.45 & +2 \\
\hline
\end{tabular}

The vehicle control was also analyzed and was below the limit of quantitation.

${ }^{b}$ Results of duplicate analyses.

'Animal room samples for rats.

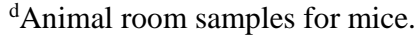

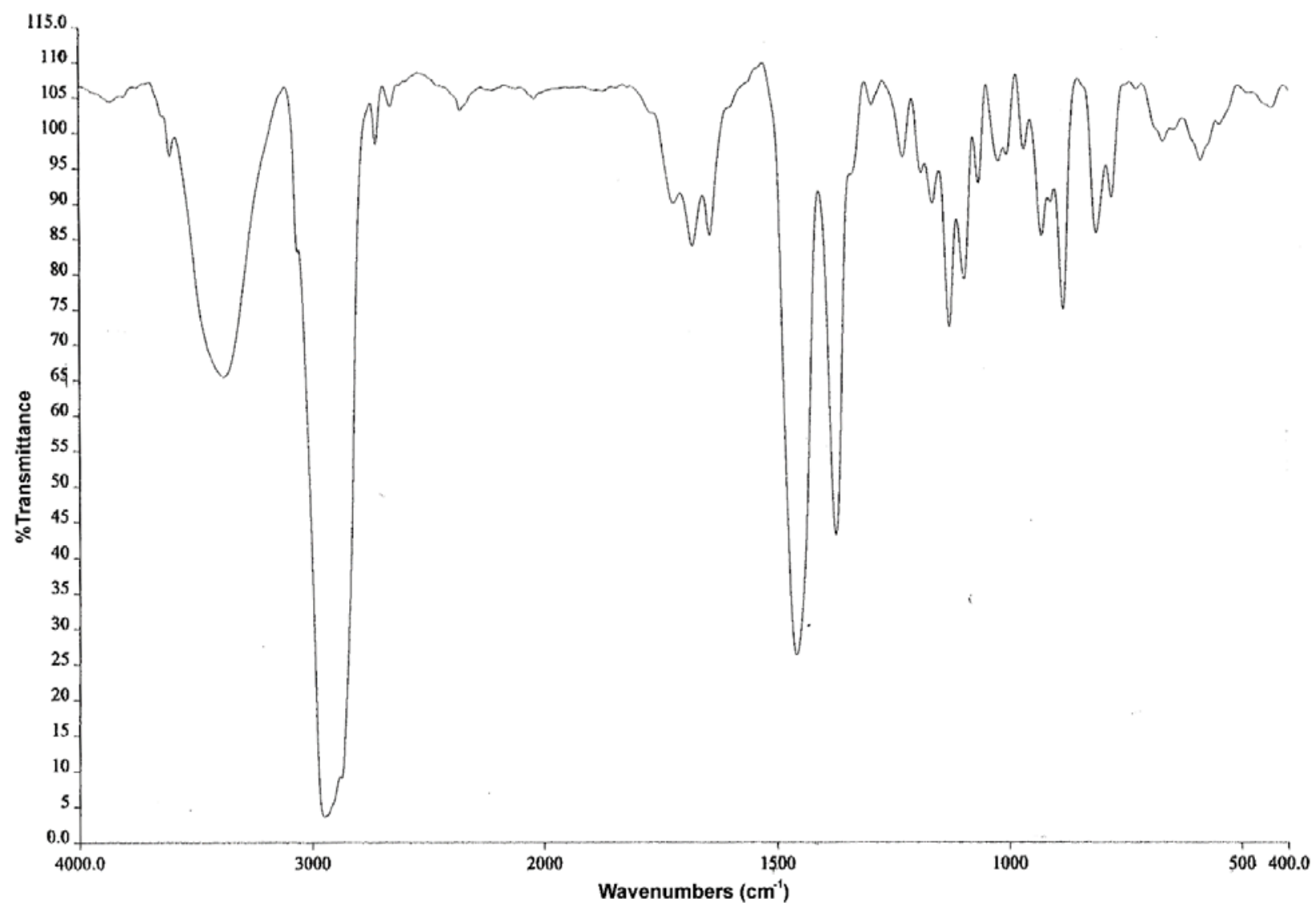

Figure F-1. Infrared Absorption Spectrum of Cedarwood Oil 
Cedarwood Oil, NTP TOX 86

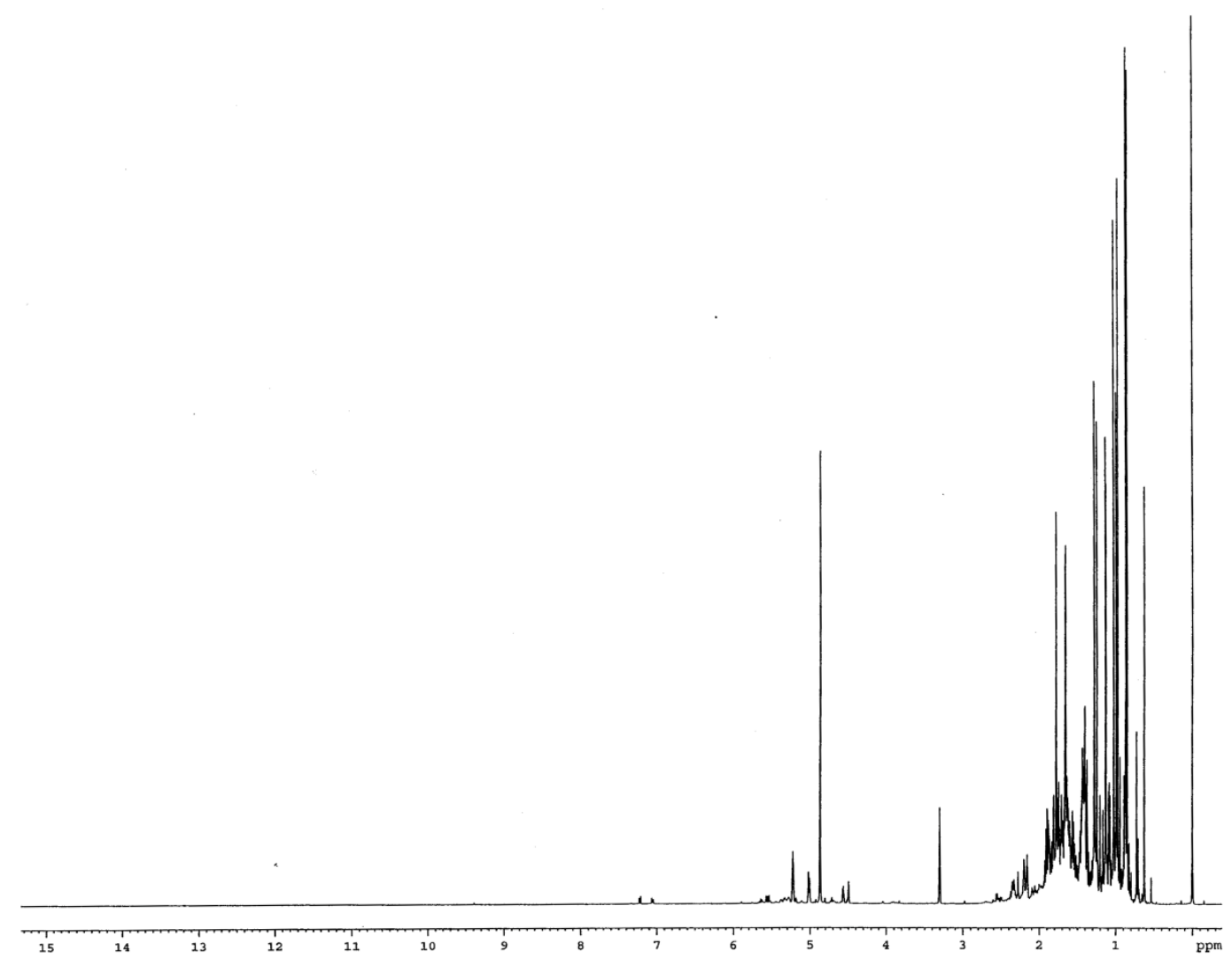

Figure F-2. Proton Nuclear Magnetic Resonance Spectrum of Cedarwood Oil 


\section{Appendix G. Ingredients, Nutrient Composition, and Contaminant Levels in NTP-2000 Rat and Mouse Ration}

\section{Tables}

Table G-1. Ingredients of NTP-2000 Rat and Mouse Ration

G-2

Table G-2. Vitamins and Minerals in NTP-2000 Rat and Mouse Ration.

G-2

Table G-3. Nutrient Composition of NTP-2000 Rat and Mouse Ration .................................. G-3

Table G-4. Contaminant Levels in NTP-2000 Rat and Mouse Ration 
Table G-1. Ingredients of NTP-2000 Rat and Mouse Ration

Ingredients

Ground hard winter wheat

Ground \#2 yellow shelled corn

Wheat middlings

Oat hulls

Alfalfa meal (dehydrated, 17\% protein)

Purified cellulose

Soybean meal (49\% protein)

Fish meal (60\% protein)

Corn oil (without preservatives)

Soy oil (without preservatives)

Dried brewer's yeast

Calcium carbonate (USP)

Vitamin premix ${ }^{\mathrm{a}}$

Mineral premix ${ }^{\mathrm{b}}$

Calcium phosphate, dibasic (USP)

Sodium chloride

Choline chloride (70\% choline)

Methionine

a'Weat middlings as carrier.

${ }^{\mathrm{b}}$ Calcium carbonate as carrier.

\section{Percent by Weight}

22.26

22.18

15.0

8.5

7.5

5.5

5.0

4.0

3.0

3.0

1.0

0.9

0.5

0.5

0.4

0.3

0.26

0.2

Table G-2. Vitamins and Minerals in NTP-2000 Rat and Mouse Ration ${ }^{\mathrm{a}}$

\begin{tabular}{lcc}
\hline & Amount & Source \\
\hline Vitamins & & \\
$\mathrm{A}$ & $4,000 \mathrm{IU}$ & Stabilized vitamin A palmitate or acetate \\
$\mathrm{D}$ & $1,000 \mathrm{IU}$ & D-activated animal sterol \\
$\mathrm{K}$ & $1.0 \mathrm{mg}$ & Menadione sodium bisulfite complex \\
$\alpha$-Tocopheryl acetate & $100 \mathrm{IU}$ & - \\
Niacin & $23 \mathrm{mg}$ & - \\
Folic acid & $1.1 \mathrm{mg}$ & - \\
d-Pantothenic acid & $10 \mathrm{mg}$ & d-Calcium pantothenate \\
Riboflavin & $3.3 \mathrm{mg}$ & - \\
Thiamine & $4 \mathrm{mg}$ & Thiamine mononitrate \\
B & $52 \mathrm{\mu g}$ & - \\
Pyridoxine & $6.3 \mathrm{mg}$ & Pyridoxine hydrochloride \\
\hline
\end{tabular}




\begin{tabular}{lcl}
\hline & Amount & \multicolumn{1}{c}{ Source } \\
\hline Biotin & $0.2 \mathrm{mg}$ & d-Biotin \\
Minerals & & \\
Magnesium & $514 \mathrm{mg}$ & Magnesium oxide \\
Iron & $35 \mathrm{mg}$ & Iron sulfate \\
Zinc & $12 \mathrm{mg}$ & Zinc oxide \\
Manganese & $10 \mathrm{mg}$ & Manganese oxide \\
Copper & $2.0 \mathrm{mg}$ & Copper sulfate \\
Iodine & $0.2 \mathrm{mg}$ & Calcium iodate \\
Chromium & $0.2 \mathrm{mg}$ & Chromium acetate \\
\hline
\end{tabular}

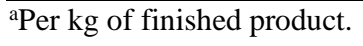

Table G-3. Nutrient Composition of NTP-2000 Rat and Mouse Ration

\begin{tabular}{|c|c|c|c|}
\hline Nutrient & Mean \pm Standard Deviation & Range & Number of Samples \\
\hline Protein (\% by weight) & $14.8 \pm 0.44$ & $14.4-15.3$ & 4 \\
\hline Crude fat (\% by weight) & $8.1 \pm 0.17$ & $7.9-8.3$ & 4 \\
\hline Crude fiber (\% by weight) & $9.3 \pm 0.46$ & $8.7-9.8$ & 4 \\
\hline Ash (\% by weight) & $4.8 \pm 0.16$ & $4.6-5.0$ & 4 \\
\hline \multicolumn{4}{|c|}{ Amino Acids (\% of total diet) } \\
\hline Arginine & $0.783 \pm 0.070$ & $0.670-0.970$ & 22 \\
\hline Cystine & $0.220 \pm 0.024$ & $0.150-0.250$ & 22 \\
\hline Glycine & $0.701 \pm 0.041$ & $0.620-0.800$ & 22 \\
\hline Histidine & $0.352 \pm 0.077$ & $0.270-0.680$ & 22 \\
\hline Isoleucine & $0.546 \pm 0.044$ & $0.430-0.660$ & 22 \\
\hline Leucine & $1.095 \pm 0.067$ & $0.960-1.240$ & 22 \\
\hline Lysine & $0.711 \pm 0.114$ & $0.310-0.860$ & 22 \\
\hline Methionine & $0.409 \pm 0.046$ & $0.260-0.490$ & 22 \\
\hline Phenylalanine & $0.628 \pm 0.040$ & $0.540-0.720$ & 22 \\
\hline Threonine & $0.505 \pm 0.043$ & $0.430-0.610$ & 22 \\
\hline Tryptophan & $0.150 \pm 0.028$ & $0.110-0.200$ & 22 \\
\hline Tyrosine & $0.401 \pm 0.061$ & $0.280-0.540$ & 22 \\
\hline Valine & $0.665 \pm 0.043$ & $0.550-0.730$ & 22 \\
\hline \multicolumn{4}{|c|}{ Essential Fatty Acids (\% of total diet) } \\
\hline Linoleic & $3.95 \pm 0.259$ & $3.49-4.55$ & 22 \\
\hline Linolenic & $0.30 \pm 0.032$ & $0.21-0.35$ & 22 \\
\hline
\end{tabular}




\section{Cedarwood Oil, NTP TOX 86}

\begin{tabular}{|c|c|c|c|}
\hline Nutrient & Mean \pm Standard Deviation & Range & Number of Samples \\
\hline \multicolumn{4}{|l|}{ Vitamins } \\
\hline Vitamin A (IU/kg) & $4,373 \pm 57$ & $3,710-5,080$ & 4 \\
\hline Vitamin D (IU/kg) & $1,000^{\mathrm{a}}$ & - & - \\
\hline$\alpha$-Tocopherol (ppm) & $80.6 \pm 22.03$ & $27.0-124.0$ & 22 \\
\hline Thiamine (ppm) $)^{\mathrm{b}}$ & $8.0 \pm 1.06$ & $6.6-9.0$ & 4 \\
\hline Riboflavin (ppm) & $7.6 \pm 2.89$ & $4.20-17.50$ & 22 \\
\hline Niacin (ppm) & $78.9 \pm 9.08$ & $66.4-98.2$ & 22 \\
\hline Pantothenic acid (ppm) & $26.9 \pm 12.63$ & $17.4-81.0$ & 22 \\
\hline Pyridoxine $(\mathrm{ppm})^{\mathrm{b}}$ & $9.54 \pm 1.99$ & $6.44-13.7$ & 22 \\
\hline Folic acid (ppm) & $1.62 \pm 0.48$ & $1.15-3.27$ & 22 \\
\hline Biotin (ppm) & $0.32 \pm 0.10$ & $0.20-0.704$ & 22 \\
\hline Vitamin $B_{12}(p p b)$ & $53.6 \pm 39.6$ & $18.3-174.0$ & 22 \\
\hline Choline (ppm) $)^{\mathrm{b}}$ & $2,846 \pm 485$ & $1,820-3,790$ & 22 \\
\hline \multicolumn{4}{|l|}{ Minerals } \\
\hline Calcium (\%) & $0.964 \pm 0.054$ & $0.903-1.030$ & 4 \\
\hline Phosphorus (\%) & $0.558 \pm 0.019$ & $0.535-0.576$ & 4 \\
\hline Potassium (\%) & $0.666 \pm 0.030$ & $0.626-0.733$ & 22 \\
\hline Chloride (\%) & $0.386 \pm 0.039$ & $0.300-0.474$ & 22 \\
\hline Sodium (\%) & $0.189 \pm 0.016$ & $0.160-0.222$ & 22 \\
\hline Magnesium (\%) & $0.216 \pm 0.062$ & $0.185-0.490$ & 22 \\
\hline Sulfur (\%) & $0.170 \pm 0.029$ & $0.116-0.209$ & 14 \\
\hline Iron (ppm) & $186 \pm 39.2$ & 135-311 & 22 \\
\hline Manganese (ppm) & $51.4 \pm 10.28$ & $21.0-73.1$ & 22 \\
\hline Zinc (ppm) & $53.4 \pm 8.46$ & $43.3-78.5$ & 22 \\
\hline Copper (ppm) & $7.01 \pm 2.562$ & $3.21-16.3$ & 22 \\
\hline Iodine (ppm) & $0.503 \pm 0.206$ & $0.158-0.972$ & 22 \\
\hline Chromium (ppm) & $0.694 \pm 0.276$ & $0.330-1.380$ & 22 \\
\hline Cobalt (ppm) & $0.256 \pm 0.164$ & $0.098-0.864$ & 22 \\
\hline
\end{tabular}

aFrom formulation.

${ }^{\mathrm{b}}$ As hydrochloride (thiamine and pyridoxine) or chloride (choline). 
Table G-4. Contaminant Levels in NTP-2000 Rat and Mouse Ration ${ }^{\mathrm{a}}$

\begin{tabular}{|c|c|c|c|}
\hline & Mean \pm Standard Deviation ${ }^{b}$ & Range & Number of Samples \\
\hline \multicolumn{4}{|l|}{ Contaminants } \\
\hline Arsenic (ppm) & $0.23 \pm 0.040$ & $0.19-0.28$ & 4 \\
\hline Cadmium (ppm) & $0.05 \pm 0.004$ & $0.04-0.05$ & 4 \\
\hline Lead (ppm) & $0.10 \pm 0.019$ & $0.08-0.12$ & 4 \\
\hline Mercury (ppm) & $<0.02$ & - & 4 \\
\hline Selenium (ppm) & $0.26 \pm 0.007$ & $0.25-0.26$ & 4 \\
\hline Aflatoxins (ppb) & $<5.00$ & - & 4 \\
\hline Nitrate nitrogen $(\mathrm{ppm})^{\mathrm{c}}$ & $8.58 \pm 0.687$ & 7.9-9.4 & 4 \\
\hline Nitrite nitrogen $(\mathrm{ppm})^{\mathrm{c}}$ & $4.6 \pm 1.27$ & $2.81-5.81$ & 4 \\
\hline BHA (ppm) $)^{d}$ & $<1.0$ & - & 4 \\
\hline BHT (ppm) ${ }^{d}$ & $<1.0$ & - & 4 \\
\hline Aerobic plate count (CFU/g) & $10 \pm 0.0$ & 10 & 4 \\
\hline Coliform (MPN/g) & $3.0 \pm 0.0$ & 3.0 & 4 \\
\hline Escherichia coli (MPN/g) & $<10$ & - & 4 \\
\hline Salmonella (MPN/g) & Negative & - & 4 \\
\hline Total nitrosoamines (ppb) ${ }^{\mathrm{e}}$ & $4.2 \pm 1.35$ & $3.2-6.1$ & 4 \\
\hline N-Nitrosodimethylamine (ppb) & $2.5 \pm 1.11$ & $1.4-3.9$ & 4 \\
\hline N-Nitrosopyrrolidine (ppb) ${ }^{\mathrm{e}}$ & $1.7 \pm 0.39$ & $1.3-2.2$ & 4 \\
\hline \multicolumn{4}{|l|}{ Pesticides (ppm) } \\
\hline$\alpha-\mathrm{BHC}$ & $<0.01$ & - & 4 \\
\hline$\beta$-BHC & $<0.02$ & - & 4 \\
\hline$\gamma$-BHC & $<0.01$ & - & 4 \\
\hline$\delta$-BHC & $<0.01$ & - & 4 \\
\hline Heptachlor & $<0.01$ & - & 4 \\
\hline Aldrin & $<0.01$ & - & 4 \\
\hline Heptachlor epoxide & $<0.01$ & - & 4 \\
\hline DDE & $<0.01$ & - & 4 \\
\hline DDD & $<0.01$ & - & 4 \\
\hline DDT & $<0.01$ & - & 4 \\
\hline HCB & $<0.01$ & - & 4 \\
\hline Mirex & $<0.01$ & - & 4 \\
\hline Methoxychlor & $<0.05$ & - & 4 \\
\hline Dieldrin & $<0.01$ & - & 4 \\
\hline Endrin & $<0.01$ & - & 4 \\
\hline
\end{tabular}




\begin{tabular}{lccc}
\hline & Mean \pm Standard Deviation & Range & Number of Samples \\
\hline Telodrin & $<0.01$ & - & 4 \\
Chlordane & $<0.05$ & - & 4 \\
Toxaphene & $<0.10$ & - & 4 \\
Estimated PCBs & $<0.20$ & - & 4 \\
Ronnel & $<0.01$ & - & 4 \\
Ethion & $<0.02$ & - & 4 \\
Trithion & $<0.05$ & - & 4 \\
Diazinon & $<0.10$ & $0.025-0.166$ & 4 \\
Methyl chlorpyrifos & $0.091 \pm 0.066$ & - & 4 \\
Methyl parathion & $<0.02$ & - & 4 \\
Ethyl parathion & $<0.02$ & $-0.233-0.500$ & 4 \\
Malathion & $0.358 \pm 0.118$ & - & 4 \\
Endosulfan I & $<0.01$ & - & 4 \\
Endosulfan II & $<0.01$ & - & 4 \\
Endosulfan sulfate & $<0.03$ & & 4 \\
\hline
\end{tabular}

${ }^{\text {aAll }}$ samples were irradiated. CFU = colony-forming units; MPN = most probable number; BHC = hexachlorocyclohexane or benzene hexachloride.

${ }^{\mathrm{b}}$ For values less than the limit of detection, the detection limit is given as the mean.

'Sources of contamination: alfalfa, grains, and fish meal.

dSources of contamination: soy oil and fish meal.

eAll values were corrected for percent recovery. 


\section{Appendix H. Sentinel Animal Program}

\section{Table of Contents}

H.1. Methods................................................................................................. H-2

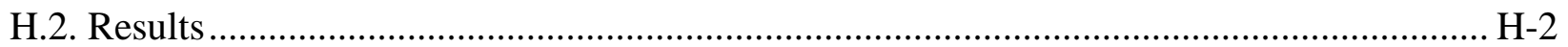

Tables

Table H-1. Laboratory Methods and Agents Tested for in the Sentinel Animal Program ......... H-2 


\section{H.1. Methods}

Rodents used in the National Toxicology Program are produced in optimally clean facilities to eliminate potential pathogens that may affect study results. The Sentinel Animal Program is part of the periodic monitoring of animal health that occurs during the toxicologic evaluation of test compounds. Under this program, the disease state of the rodents is monitored via sera or feces from extra (sentinel) or dosed animals in the study rooms. The sentinel animals and the study animals are subject to identical environmental conditions. Furthermore, the sentinel animals come from the same production source and weanling groups as the animals used for the studies of test compounds.

Blood samples were collected, allowed to clot, and the serum was separated. The serum samples were processed appropriately, sent to BioReliance Corporation (Rockville, MD), and evaluated for the presence of pathogens. The laboratory methods and agents for which testing was performed are tabulated below; the times at which samples were collected during the studies are also listed.

Table H-1. Laboratory Methods and Agents Tested for in the Sentinel Animal Program

\begin{tabular}{|c|c|}
\hline Method and Test & Time of Collection \\
\hline \multicolumn{2}{|l|}{ Rats } \\
\hline \multicolumn{2}{|l|}{ ELISA } \\
\hline PVM (pneumonia virus of mice) & Study start, 4 weeks, study termination \\
\hline RCV/SDA (rat coronavirus/sialodacryoadenitis virus) & Study start, 4 weeks, study termination \\
\hline Sendai & Study start, 4 weeks, study termination \\
\hline \multicolumn{2}{|l|}{ Immunofluorescence Assay } \\
\hline Parvovirus & Study start, 4 weeks, study termination \\
\hline \multicolumn{2}{|l|}{ Mice } \\
\hline \multicolumn{2}{|l|}{ ELISA } \\
\hline Ectromelia virus & Study start, 4 weeks, study termination \\
\hline EDIM (epizootic diarrhea of infant mice) & Study start, 4 weeks, study termination \\
\hline GDVII (mouse encephalomyelitis virus) & Study start, 4 weeks, study termination \\
\hline LCM (lymphocytic choriomeningitis virus) & Study start, 4 weeks, study termination \\
\hline Mouse adenoma virus-1 & Study start, 4 weeks, study termination \\
\hline MHV (mouse hepatitis virus) & Study start, 4 weeks, study termination \\
\hline MMV VP2 (mouse minute virus) & Study start, 4 weeks, study termination \\
\hline MPV VP2 (mouse parvovirus) & Study start, 4 weeks, study termination \\
\hline PVM & Study start, 4 weeks, study termination \\
\hline Reovirus & Study start, 4 weeks, study termination \\
\hline Sendai & Study start, 4 weeks, study termination \\
\hline
\end{tabular}

\section{H.2. Results}

All test results were negative. 


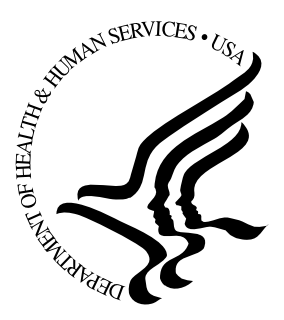

\title{
National Toxicology Program
}

\author{
NTP Central Data Management, MD EC-03
}

National Institute of Environmental Health Sciences

P.O. Box 12233

Research Triangle Park, NC 27709

http://ntp.niehs.nih.gov 